\title{
Article
}

\section{The President's Power To Execute the Laws}

\author{
Steven G. Calabresi ${ }^{\dagger}$ and Saikrishna B. Prakash"
}

CONTENTS

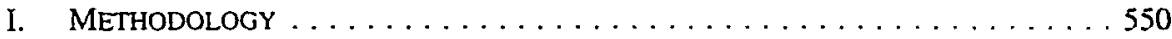
A. The Primacy of the Constitutional Text $\ldots \ldots \ldots \ldots \ldots \ldots \ldots \ldots 51$

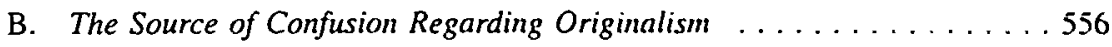
C. More on Whose Original Understanding Counts and Why . . . . . 558

II. The Textual Case for a Trinity of Powers and of Personnel . . . . 559

A. The Constitutional Text: An Exclusive Trinity of Powers . . . . . . . 560

B. The Textual Case for Unenumerated Powers of Government Is Much Harder To Make than the Case for Unenumerated Individual Rights . . . 564

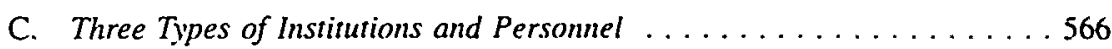

D. Why the Constitutional Trinity Leads to a Strongly Unitany Executuve . . 568

$\div$ Associate Professor, Northwestern University School of Law. B.A. Yale Universily, 1980, JD. Yale University, 1983.

i† B.A., Stanford University. 1990: J.D.. Yale Universily. 1993. The authors are very graleful for the many helpful comments and suggestions of Akhil Reed Amar. Perry Bechky. John Harnson. Gary Lawson. Lawrence Lessig. Michael W. McConnell. Thomas W. Merrill. Geoffrey P. Miller, Henry P Mionaghan. Alex Y.K. Oh, Michael J. Perry. Martin H. Redish. Peter L. Strauss. Cass R. Sunstesn. Mlary S Tyler, and Cornelius A. Vermeule. We particularly thank Lam Lessig and Cass Sunstein for graciously shanng with us numerous early drafts of their article. Finally, we wish to note that this Aricle is the synthesis of two separate manuscripts prepared by each of us in response to Professors Lessig and Sunstein. Professor Calabresi's manuscript developed the originalist textual arguments for the untary Exccutuve, and Mr Prakash's manuscript developed the pre- and post-ratıfication histoncal arguments. We are deeply grateful to Akhil Reed Amar for encouraging us to collaborate and to the editors of The Yale Law Joumul for allowing us to present jointly our mutually reinforeng arguments for the unitary Execuluve here 
III. The Textual Case for the Unitary Executive $\ldots \ldots \ldots \ldots \ldots \ldots \ldots 70$

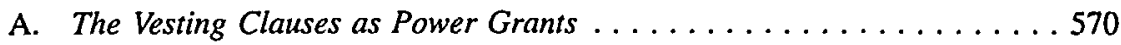

1. The Analogy Between the Vesting Clauses of Article II and Article $I I I \ldots \ldots \ldots \ldots \ldots \ldots \ldots \ldots \ldots \ldots \ldots \ldots$

2. The Plain Meanings of the Verbs "Vest" and "Extend" . . . . . 572

3. There Is No Implicit "Herein Granted" in Article II's Vesting Clause . . . . . . . . . . . . . . . . . . 574

4. Reading the Vesting Clause of Article II To Be a Power Grant Does Not Make the Rest of Article II Superfiuous . . . . . . . . 576

5. The Minimalist Plain Meaning of Executive Power . . . . . . . 579

B. The President's Constitutional Grant of the Executive Power Is Exclusive:

It Is Not Concurrently Shared with the Congress ...........581

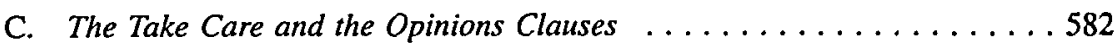

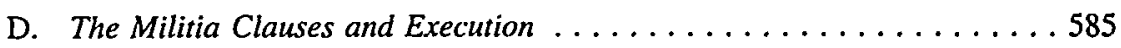

E. The Relevance of the Necessary and Proper Clause . . . . . . . 586

1. The Relevance of the Word "Proper" . . . . . . . . . . . 587

2. The Relevance of "Carrying into Execution" ...........588

3. There Is No Special Relationship Between the Take Care and the Necessary and Proper Clauses . . . . . . . . . . . . . . 589

4. The Real Purpose of the Clause . . . . . . . . . . . . . 590

5. Creating Offices and Cabinet Departments . . . . . . . . . . 592

F. The President's Power To Execute the Laws: Three Constitutionally Necessary Mechanisms To Control Inferior Executive Officers . . . . . 593

G. Summary of the Textual Argument of Parts II and III . . . . . . . 599

IV. SOME PRE-Framing Historical Context: The Continental Congress'

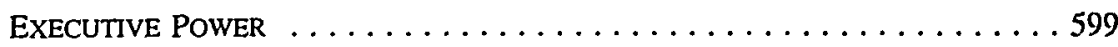

V. THE PRE-RATIFICATION UNDERSTANDING OF THE PRESIDENT'S ROLE IN THE AdMINISTRATION of FEderal LAW $\ldots \ldots \ldots \ldots \ldots \ldots \ldots \ldots \ldots \ldots$

A. The Executive Power Clause and the Administrative Power . . . . . . . 604

1. Political Theorists: Locke, Blackstone, and Montesquieu . . . . . 605

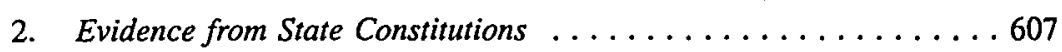

3. The Philadelphia Convention ................... 607

4. The Public Ratification Debates . . . . . . . . . . . . 610

5. Lessig and Sunstein's Historical Arguments for Not Treating the Vesting Clause of Article II as a Vesting Clause . . . . . . 612

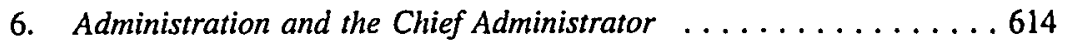

B. The Take Care Clause . . . . . . . . . . . . . . . 616

1. The State Ratification Debates . . . . . . . . . . . 617

2. The Public Debate Outside the Conventions . .......... 618

3. The Limits of the Take Care Clause . . . . . . . . . . 620 
C. The Necessary and Proper Clause . . . . . . . . . . . 622

1. The Clause Is About Providing the Means To Effectuate Powers of the Three Branches . . . . . . . . . . . . . . .623

2. Limitations on the Use of the Clause . . . . . . . . . . 624

3. Prescient Warnings About the Possibilities of Abuse . . . . . . 624

4. Are We Still Under the Articles of Confederation? . . . . . . . 625

D. The Opinions Clause, Principal Officers, and Deparment Heads . . . .626

1. The Two Interpretations of the Opinions Clause . . . . . . . 626

2. The Flaws of the Radical Reading . . . . . . . . . . . 627

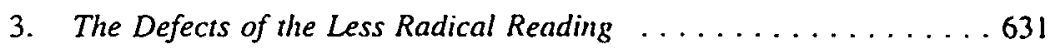

4. The True Meaning of the Clause ................ 633

E. A Review of the Pre-Ratification Original Understanding of the Constitution . . . . . . . . . . . . . 635

VI. POST-RATIFICATION UNDERSTANDINGS OF the PRESIDENT'S

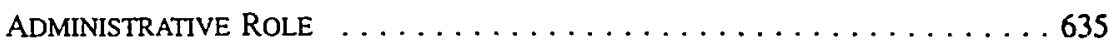

A. Washington's Administrative Understanding . . . . . . . . . 637

1. The Chief Executive and Other Federal Executives ... . . . 6637

2. The Federal Chief Executive and the State Executives ........6639

B. A Conflicted Congress' Views Regarding Presidential Administration:

Early Removal Debates . . . . . . . . . . . . . . . . . . . 642

C. Administrative Practice Under Cersain Statutes . . . . . . . . 646

1. Was Treasury an Executive Department . . . . . . . 647

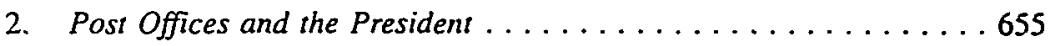

3. The Prosecutorial Power and the President ...........668

D. Some Final Thoughts on Post-Ratification Views of the President's

Administrative Role . . . . . . . . . . . . 661

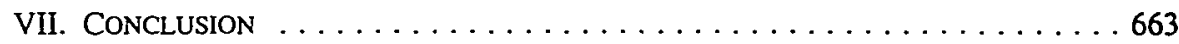

Conventional wisdom insists that the Framers believed in a hierarchical executive branch, with the President in charge of all administration of the laws. . . . There is no historically sound reading of the Constitution that compels anything like [this] claim. Any faithful reader of history must conclude that the unitary executive. conceived in the foregoing way, is just myth.'

Lawrence Lessig and Cass Sunstein

1. Lawrence Lessig \& Cass R. Sunstein. The President and the Administration. 94 COLUM. L. REV. 1, 4 (1994) (emphasis added). 
If the Constitution has invested all executive power in the President, I venture to assert that the Legislature has no right to diminish or modify his executive authority. . . . I conceive that if any power whatsoever is in its nature executive, it is the power of appointing, overseeing, and controlling those who execute the laws. ${ }^{2}$

James Madison

One of the oldest debates in American constitutional law has concerned the scope of Congress' alleged "power" to carve up the executive department of the federal government into minifiefdoms independent of presidential control. From the Decision of 1789 to the controversy over the Tenure in Office Act, down through recent Supreme Court opinions, Presidents, members of Congress, judges, and scholars have disagreed over whether Article II of the U.S. Constitution, as originally understood, creates a strongly "unitary" Executive. After two hundred years, no scholarly or judicial consensus has yet emerged on this vital question of the proper scope of presidential power.

That such a question should remain unresolved for so long is in some ways quite odd. The claim made by unitary executivists that the Constitution creates only three branches of government and that the President must be able to control the execution of all federal laws is easily understood and resonates strongly with the very earliest lessons we learn about our constitutional system. In grade school, we are taught that our nation's laws are made by the Congress, executed by the President, and adjudicated in specific cases by the federal courts. By junior or senior high school, when we are first introduced to the constitutional text, we quickly learn that it vests certain legislative powers with the Congress, the executive power with the President, and the judicial power with the Supreme Court and inferior federal courts. At some point along the way, many of us put two and two together and conclude that the Congress' grants of legislative powers must enable it to legislate, the President's grant of the executive power must enable him to execute all federal laws, and the federal judiciary's grant of the judicial power must enable the federal courts to decide certain cases and controversies.

It is thus perhaps a bit surprising to arrive at law school and discover that this "high school civics" conception of the separation of powers, particularly presidential control over execution of the laws, has for some time now been out of favor. The modern academic debate about presidential power to execute the laws began promisingly in 1984 with a leading article by Professor Peter Strauss, who argued thoughtfully for the constitutionality of some agency "independence," while recognizing that the President had to retain at least

2. 1 ANNALS OF CONG. 463 (Gales \& Seaton eds., 1789). 
minimal powers of control over all federal law execution. ${ }^{3}$ Over the next few years, a number of prominent scholars, led by Professors Geoffrey Miller and Stephen Carter, weighed in forcefully on the unitary executivist side, arguing in favor of full presidential control of all execution of the laws." These unitary executivist scholars were followed by scholars arguing that the President need not have any control over at least some law-execution activities. ${ }^{5}$ Recently, the weight of academic opinion has shifted back to the theory of the unitary Executive. ${ }^{6}$

The most recent contribution to this growing body of scholarship is The President and the Administration, ${ }^{7}$ a seminal article by Professors Lawrence Lessig and Cass Sunstein. They conclude that, notwithstanding its many academic advocates and its firm textual foundations, the theory that the Framers of our Constitution meant to create a strongly unitary Executive is "just plain myth." According to Lessig and Sunstein, the theory

is a creation of the twentieth century, not the eighteenth. It derives from twentieth century categories applied unreflectively to an eighteenth century document. It ignores strong evidence that the framers imagined not a clear executive hierarchy with the President

3. Peter L. Strauss, The Place of Agencies in Govermment: Separanon of Powers and the Fourth Branch, 84 COLUM. L. REv. 573, 597 (1984) (asserting that whatever the administralive arrangements, President must be "politically accountable head of all law-admustration").

4. See Geoffrey P. Miller. Independent Agencies. 1986 SuP. CT. REv. 41 : Stephen L. Carter. Comment. The Independent Counsel Mess. 102 HaRV. L. REV. 105 (1988); see also David P. Cume. The Disiribution of Powers After Bowsher, 1986 SUP. CT. REV. 19.

5. See A. Michael Froomkin. The Imperial Presidenci's New Vestments. 88 Nw. U L REV 1346 (1994) [hereinafter Froomhin, New Vestments]; Bruce Ledewitz. The Uncertain Pawer of the Prestdent To Execute the Lau's, 46 TENN. L. REV. 757 (1979); Morton Rosenberg. Congress's Prerogatuve over Agenctes and Agency Dectsionmakers: The Rise and Demuse of the Reagan Admustration's Theary of the Unuary Executive, 57 GEO. WASH. L. REV. 627 (1989); A. Michael Froomkın. Note. In Defense of Adnumustratrve Agency Autonomy. 96 YALE L.J. 787 (1987) [hereinafter Froomkın. Agency Autonomy]

6. See Harold J. Krent, Fragmenting the Untan Executwe: Congressional Delegations of Administrative Authorty. Outside the Federal Govermment. 85 Nw. U. L. REv. 62. 72-82 (1990): Gary Lawson, The Rise and Rise of the Administratue Stale, 107 HARV. L. REV. 1231 (1994): Lee S. Luberman, Morrison v. Olson: A Formalist Perspective on Why the Court Was Wrong. 38 A.M. U. L. Rev 313 (1989): Thomas W. Merrill, The Constiturional Principle of Separatıon of Powers. 1991 SUP. CT. REV 22S: Martin H. Redish \& Elizabeth J. Cisar, "If Angels Were to Govern": The Need for Pragmanc Formalism in Separation of Powers Theory. 1992 DUKE L.J. 449. For an exceptionally thoughtful explicauon of the theory of Article II that underlies the unitary Executive position, see Henry P. Monaghan. The Protective Power of the Presidency, 93 CoLUM. L. REV. 1, 3. 16 (1993) (assering that Constitution appears to contemplate only a "law enforcement" Executive and that Philadelphia conventuoneers constructed "strong. legally and politically independent chief Executive who could enforce national law").

Both of us contributed to this latest group of articles favoring a unitary Exceuture. See Steven G. Calabresi \& Kevin H. Rhodes. The Structural Constututon: Unutan Executtre. Plural Judiciany. 10S HaRv. L. REV. 1153 (1992); Saikrishna B. Prakash. Note. Hall to the Chef Admintstrator: The Framers and the President's Administrative Powers, 102 Y ALE L.J. 991 (1992).

Of course, in some sense all Aricle Il scholars believe the Constutution creates a unitany Executive. Those who believe in what has come to be called the theory of the unitary Executuve contend that the Constitution requires effective presidential control of all exercises of the exceuuve power. We shall apply the "unitarian" label throughout this Article to denote this "strong" unitarian posttion

7. Lessig \& Sunstein, supra note 1. 
at the summit, but a large degree of congressional power to structure the administration as it thought proper. ${ }^{8}$

Thus, Lessig and Sunstein say the originalist case for a unitary Executive is fanciful and that executive unitarianness may only be compelled today because "changed circumstances since the eighteenth century" have led to a mutation in the original design. Those who wish to be "faithful to the framers' constitutional design" 10 must either reject the unitary Executive or give up the originalist banner. All originalists who are also unitarians" are thus politely shown to be in need of a refresher course in American legal history.

We disagree. We feel compelled to revisit this question to respond to the many interesting issues raised by Lessig and Sunstein's provocative analysis. While Lessig and Sunstein's recent contribution to the unitary Executive debate is informative and valuable, we find it unpersuasive because we believe it focuses far too much on what they think the Framers must have "imagined," 2 while overlooking the original meaning of the words of the constitutional text that the Framers actually wrote.

To the extent that Lessig and Sunstein wish to advance an originalist constitutional argument, we believe that their piece is methodologically flawed. Lessig and Sunstein err, in our view, because they give dispositive weight to an incomplete rendition of the relevant history over the legal text itself. Thus, this Article's first project is to demonstrate that their arguments against the theory of the unitary Executive should fail to persuade anyone who considers herself an originalist (or a textualist). ${ }^{13}$

Just as critically, we also believe that Lessig and Sunstein have failed to place the Article II debate in its proper historical context. In our judgment, more attention must be given to the relevant pre-1789 history: the history of

8. Id. at 2.

9. Id. at 3. In "transiating" the Constitution for modern times, Lessig and Sunstein ultimately claim that the Constitution requires some degree of presidential control over some types of law execution. See id. at 85-105. We disagree that such translation is necessary, and, more important, we believe that the Constitution as originally understood mandates a strongly unitary Executive. Nonetheless, we do not quarrel with most of their argument from changed circumstances, except to the extent it rests on their originalist rejection of the unitary Executive. Indeed, one of us has presented an argument for executive unitarianism based on changed circumstances that is not at all dissimilar to Lessig and Sunstein's argument. Steven G. Calabresi, Political Parties as Mediating Institutions, 61 U. CHI. L. REV. 1479, 1498-1506 (1994) [hereinafter Calabresi, Political Parties]; Steven G. Calabresi, Some Normative Arguments for the Unitary Executive, 47 ARK. L. REV. (forthcoming Dec. 1994) [hereinafter Calabresi, Some Normative Arguments].

10. Lessig \& Sunstein. supra note 1 , at 4.

11. In recent years, supporters of originalism in constitutional interpretation have also tended to be supporters of the theory of the unitary Executive. Compare Antonin Scalia, Originalism: The Lesser Evil, 57 U. CIN. L. REv. 849 (1989) (defending originalism) with Morrison v. Olson, 487 U.S. 654, 697 (1988) (Scalia, J., dissenting) (defending theory of unitary Executive).

12. Lessig \& Sunstein, supra note 1, at 2 (emphasis added).

13. We hope our analysis persuades both original- and present-meaning textualists alike. For an excellent discussion of some of the differences between these two forms of textualism, and an argument in favor of original-meaning textualism, see Steven D. Smith, Law Without Mind, 88 MICH. L. REV. 104 (1989). 
executive structures under the Articles of Confederation and the discussions of Article II at the Philadelphia Convention and at the state ratifying conventions. Similarly, analysis of the relevant post-ratification history must include President Washington's views of the scope of his administrative powers, his actual administrative practices, and the legislative history of the acts of the early Congresses. Thus, the second project of this Article is to paint what we hope will be a more complete and accurate picture of the history underlying the original understanding of the President's power to execute the laws. We believe that there is no better way to begin our projects than by responding to the ambitious claims made by Lessig and Sunstein. They have skillfully laid bare all the key issues, even if they have, in our judgment, failed to persuade.

Before proceeding further, we must briefly summarize the Lessig and Sunstein thesis. They argue that although the Constitution commits certain "executive" tasks to the President (such as the direction of foreign and military affairs), the administration of all federal laws is not one of those exclusively executive tasks. Instead, Lessig and Sunstein claim that Congress has the power to choose whether the President will or will not be able to control the execution (or administration) of certain "administrative" laws. ${ }^{14}$ In their view, Congress was originally empowered to make the execution of these "administrative" laws entirely independent of the President. This argument amounts to an implicit claim that the Framers believed there was a fourth "administrative" power of government, ${ }^{15}$ which Congress could vest as it saw fit.

The argument for these propositions is mainly historical, relying heavily on interpretation of the early statutes creating the first Cabinet departments and other executive entities passed by the first several Congresses. Presuming that these statutes faithfully and accurately reveal the original understanding of the Constitution itself, Lessig and Sunstein claim that these statutes suggest that the Framers did not believe that the President possessed the constitutional authority to control the execution of all federal laws. ${ }^{16}$ At the same time, Lessig and Sunstein seek to connect their interpretation of the early statutes creating the departments to the Constitution's text. This allows them to generate their own rendition of the Framers' original understanding of the scope of the President's law-execution powers. Lessig and Sunstein claim that

14. See Lessig \& Sunstein, supra note 1, at 46 (discussing difference belween "executuve" and "administrative" laws).

Because one of the theses of this Article is that execution and administration of law are one and the same. we use these terms interchangeably. Though they appear to prefer the term "administration." Lessig and Sunstetn seem to regard each as a substutute for the other. See id. at 4 n.s.

15. By 1787, the three traditional powers of government consisted of the legislative, the executive, and the judicial powers. See infra part V.A.J.

16. Although Congress sometimes explicitly sancuoned presidential control of officers, it did not always do so. Accordingly. Lessig and Sunstein read the absence of statutory language reaffirming the President's constitutional powers of control over all exereises of law execulion as a congressional rejection of any such constitutionally based presidentıal power. 
notwithstanding the Constitution's explicit grant of "the executive Power" to the President, ${ }^{17}$ and notwithstanding the Take Care Clause duties that the Constitution imposes upon him, ${ }^{18}$ Congress nonetheless has broad power to decide, under the Necessary and Proper Clause, ${ }^{19}$ which federal laws the President should be able to administer. ${ }^{20}$

The only constitutional constraint that Lessig and Sunstein identify on congressional ability to divest the President of the power to control those who execute laws is a very limited and subtle one. In their view, the Constitution distinguishes between executive Cabinet departments and so-called administrative Cabinet departments, with only the former firmly under the President's control. The former are led by "principal officers," while the latter are led by "Heads of Departments." According to Lessig and Sunstein, this distinction is highly significant and might indicate that the President can demand opinions in writing only from the principal officers who supervise executive departments and not from those who manage administrative departments. Lessig and Sunstein claim that the First Congress appreciated all of these distinctions and wrote them into the statutes that set up our first departments. ${ }^{21}$

While Lessig and Sunstein have assembled much interesting history in The President and the Administration, their originalist argument suffers from fatal methodological, textual, and historical flaws. Part I addresses the methodological flaws. We show that Lessig and Sunstein have misdescribed and misapplied originalism in reaching their conclusion that no faithful originalist ${ }^{22}$ can believe that the Framers meant to constitutionalize "a hierarchical executive branch, with the President in charge of all administration of the laws." ${ }^{23}$ No originalists that we know of have ever used (or tried to defend) the methodology that Lessig and Sunstein employ. In our view, they

17. U.S. CONST. art. II, $\$ 1, \mathrm{cl} .1$.

18. Id. art. II, $\$ 3$, cl. 3 .

19. Id. art. I, $\$ 8, \mathrm{cl} .18$.

20. See Lessig \& Sunstein, supra note 1, at 66-69.

21. Thus, they note that Congress created two departments that it denominated "executive" (the Departments of Foreign Affairs and of War) to be headed by "principal officers." At the same time, it created one generic department (the Department of the Treasury) led by a "Head." Id. at 27, 34. Lessig and Sunstein explain that, as an original matter, whenever Congress created institutions to carry into execution laws passed pursuant to Article I (so-called administrative laws, such as those involving spending or the postal service), it could have chosen to create an "administrative" department independent of the President. But where a department was instituted to execute some power conferred by the text of Article II (such as direction of the military), the department so created had to be made an "executive" one because it was administering specifically enumerated presidential powers. Id. at $46,71$.

22. "We think that the conventional wisdom is wrong" in holding "(1) that the framers believed in a hierarchical executive branch, with the President in charge of all administration of the laws, and (2) that we must also ensure a hierarchical executive branch, at least if we are to be faithful to the framers' constitutional design." Id. at 4 (footnotes omitted). Lessig and Sunstein thus assert that "[a]ny faithful reader of history must conclude that the unitary Executive, conceived in the foregoing way, is just myth." Id.

23. Id. 
err by first focusing on postenactment legislative history and only later conducting an analysis of the text and structure." In Part II, we begin our textual analysis and take issue with what we believe is a core assumption of the Lessig and Sunstein article: their belief that the Constitution contemplates a fourth unenumerated power of government-an administrative power to be vested by Congress. ${ }^{25}$ We conclude that the very idea that such a power might exist "is a creation of the twentieth century, not the eighteenth."

Continuing our textual analysis in Part III, we endeavor to show that the unitary Executive thesis holistically explains how the United States Constitution allocates the power of law execution and administration to the President alone. The Executive Power Clause ${ }^{27}$ actually does what it says it does, i.e., it vests (or grants) a power over law execution in the President, and it vests that power in him alone. This construction of the Clause is fully supported by the other relevant constitutional provisions. Finally, we conclude our textual analysis by looking at three means available to the President for exercising control over the executive branch.

In Part IV, we begin our historical analysis, focusing on the period before the Constitution was adopted so that we can see what kinds of problems the Framers perceived with the arrangements for handling executive power between 1776 and 1789. Then, in Part V, we turn to a survey of the actual views of the founding generation on the scope of the President's law-execution powers prior to the Constitution's ratification. We show that the ratification debates support the textual arguments made in Part III and cast doubts on Lessig and Sunstein's attempt to build an executive/administrative distinction into the Constitution. Finally, in Part VI, we reach the material with which Lessig and Sunstein very oddly chose to begin-the postenactment legislative history of Article II generated in Congress, an institutional rival of the President. We think the historical evidence taken as a whole demonstrates that the case for a hierarchical executive branch under the control of the President is overwhelming and fully supports all of our textual claims.

24. Lessig and Sunstein describe the first part of their article as an exploration "on onginalist grounds. [of] which version of unitariness is embodied in the Constutution " $J d$. at 11 They explain that they understand originalism to require the interpreter to ask whether the modern unitanan's limitations on Congress" power were indeed understood as such by those who ratufied the Constitution. As Justice Scalia has stated the test, the onginalist would ash whether (1) the text standing alone contains strong unitarian limitations, or (2) whether strong umtanan limtations were so well understood at the founding so as to be implied by the document itself

Id. at 10-11 (citing Harmelin v. Michigan. 501 U.S. 957 (1991)) Scalıa's test clearly and emphatıcally warns originalists that they must begin their analysis with the text. but "|r|ather than beginnung with text or structure alone, [Lessig and Sunstein] begin with history." $/ d$. at 13

25. While Lessig and Sunstein attempt to deny at vanous points that they are advaatung the existence of such a power, we believe there is simply no other way to capture the essence of thear thesis

26. Lessig \& Sunstein, supra note 1 , at 2.

27. We use the term "Executive Power Clause," excepi when companng the Vesung Clauses of the first three Articles, instead of the more familiar designation "Artıcle II Vesung Clause." because we believe that the former more accurately describes the relevant constitutional provision 
Our thesis is that either the text or the relevant "legislative" history, considered separately, demonstrates that the founding generation fully embraced and wrote into the Constitution the "myth" of a chief administrator constitutionally empowered to administer all federal laws. We think the originalist textual and historical arguments for the unitary Executive, taken together, firmly establish the theory.

\section{METHODOLOGY}

We begin at the most abstract level, that is, with methodology. The Lessig and Sunstein thesis rests on some commonly held, but erroneous, ideas about originalism. They essentially equate the original understanding of the constitutional text with what they believe to have been the intentions of some of the people who lived around the time when the text was written. We might normally be tempted to pass over such an error, but it is vital that the error be exposed here, in the context of the Article II debate, since, as we will show, the text here is clear. The key difficulty with the Lessig and Sunstein argument is simply this: We do not believe they have assembled the history they relate into an argument that originalists or textualists will find compelling. ${ }^{28}$ This problem would exist in our view even if we agreed with their analysis of the relevant history. Thus, before we can even begin to address the textual and historical arguments for the unitary Executive, we must consider questions of methodology.

We make three principal points regarding originalist methodology. First and foremost, in interpreting text, commonsensically enough, one ought to begin with the text. One should have recourse to history only where one could assert plausibly that an ambiguity exists. Second, though it is true that originalists have in the past made arguments based exclusively on history, they were forced to do so because the textual provisions that they were scrutinizing were more open-ended than are the provisions relevant to the unitary Executive debate. Thus, when prior originalist scholarship has looked to history, it has always done so in a manner consistent with the primacy of the law of the text. Originalists do not believe that present-day Americans are bound by historical events or opinions that were not written into the Constitution. Finally, even after having demonstrated a textual ambiguity, no originalist should rely exclusively upon the Constitution's postenactment "legislative" history, which

28. We recognize, of course, that many thoughtful constitutional scholars reject originalism and textualism and will therefore be untroubled by our pointing out how Lessig and Sunstein's argument violates some tenets of originalist methodology. It is not our purpose here to provide a defense of originalism or of textualism from the many attacks that have been made upon it, or even to explain originalist or textualist methodology fully. Either of those projects would take us far afield. Rather, we wish to show that the argument of Lessig and Sunstein's article is inconsistent with originalist methodology and that they are therefore wrong in reaching their conclusion that "the framers' constitutional design" does not require "a hierarchical executive branch." Lessig \& Sunstein, supra note 1, at 4. 
is, after all, the history that is least likely to reflect the original understanding. It is better to examine exhaustively the pre-ratification material first and only look at the post-ratification material if it is absolutely necessary to do so.

\section{A. The Primacy of the Constitutional Text}

At the outset we remind the reader that Lessig and Sunstein's core thesis is that "the view that the framers constitutionalized anything like [a unitary Executive] is just plain myth." 29 corollary to this thesis is their additional claim that any faithful originalist must join them in reaching this conclusion. ${ }^{30}$ The truth or falsity of the Lessig and Sunstein thesis and its corollary rests upon some implicit ideas of how it is that we can ever say that the Framers succeeded in "constitutionalizing" anything. Implicit ideas must also exist to explain how it is that we can ever know what exactly it is that has been "constitutionalized."

Constitutional originalism purports to offer an answer to both of these questions. Briefly put, the answer is that the text of the Constitution, as originally understood by the people who ratified it, is the fundamental law of the land. ${ }^{31}$ This is the explanation that Chief Justice John Marshall gave in Marbury v. Madison ${ }^{32}$ when he explained why the federal courts should decide cases or controversies in accord with the Constitution even when faced with a conflicting act of Congress. The central premise of originalism (and of Marshall's opinion in Marbury) is that the text of the Constitution is law that binds each and every one of us until and unless it is changed through the procedures set out in Article V. ${ }^{33}$ It follows that the Constitution is thus like

29. Id. at 2 .

30. Id. at 4. "[W]e suggest . . there is a different model of the onganal executuve that better captures the original design." Id. at 14.

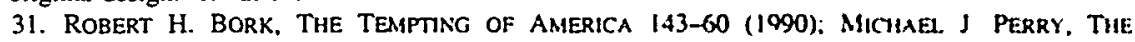
CONSTITUTION IN THE COURTS: LAW OR POLITICS? 28-53 (1994): Richard S Kay. Adherence to the Original Intentions in Constitutional Adjudication: Three Objections and Responses. 82 NW U L. ReV 226, 230 (1988) [hereinafter Kay, Adherence to the Onginal Intenuons] ("The model I discuss calls for judges to apply the rules of the written constitution in the sense in which those rules were understood by the people who enacted them."); see also Scalia, supra note 11. at 854 ("The pnocipal theoretıcal defect of nonoriginalism ... is its incompatibility with the very pnnciples that legutumize judictal review of constitutionality."); Smith, supra note 13, at 104 (defending originalısm as methodology of interpretung "enacted law-primarily, statutes and the Constitution").

32. 5 U.S. (1 Cranch) 137 (1803).

33. As Judge Bork has explained:

When we speak of "law," we ordinarily refer to a rule that we have no nght to change except through prescribed procedures. That statement assumes that the rule has a meaning independent of our own desires. Otherwise there would be no need to agree on procedures for changing the rule. Statutes, we agree, may be changed by amendment or repeal. The Constutution may be changed by amendment pursuant to the procedures set out in Aricle $V$. It is a necessary implication of the prescribed procedures that neither statute nor Constutution should be changed by judges. Though that has been done often enough. it is in no sense proper.

BORK, supra note 31 , at 143; see id. at 171-76; see also PERRY, supra note 31, at 29-31 Of course, as Richard Kay has pointed out, "Bork's assumption that the Constitution is law is itself controverstal." Richard S. Kay, The Bork Nomination and the Definution of "the Constutution". 84 NW U L. REV 1190. 
other legal writings, including statutes, contracts, wills, and judicial opinions. ${ }^{34}$ The meaning of all such legal writings depends on their texts, as they were objectively ${ }^{35}$ understood by the people who enacted or ratified them. ${ }^{36}$ Originalists do not give priority to the plain dictionary meaning of the Constitution's text because they like grammar more than history. They give priority to it because they believe that it and it alone is law. ${ }^{37}$

For these reasons, there exists a standard methodology of originalism that sets out a hierarchy of originalist source materials. This standard methodology has been endorsed or utilized to some degree or another by writers as varied as Professor Akhil Reed Amar, ${ }^{38}$ former Judge Robert H. Bork, ${ }^{39}$ Professor John Hart Ely, ${ }^{40}$ and Justice Antonin Scalia. ${ }^{41}$ This hierarchy directs

1192 (1990). We recognize that many of those who reject originalism do so, in part, because they disagrec with the claim that the Constitution is law.

34. BORK, supra note 31 , at 144-45.

35. As Bork explains again:

The search is not for a subjective intention. . . [W]hat counts is what the public understood. Law is a public act. Secret reservations or intentions count for nothing. All that counts is how the words used in the Constitution would have been understood at the time. The original understanding is thus manifested in the words used and in secondary materials, such as debates at the [ratifying] conventions, public discussion, newspaper articles, dictionaries in use at the time, and the like.

Id. at 144; see also PERRY, supra note 31, at 42-47 (defending sophisticated originalism over "strict intentionalism"); Kay, Adherence to the Original Intentions, supra note 31, at 273-81. The focus on public original meaning explains why originalist textualism can legitimately use external accounts of the meaning of language, even though it should not be guided by legislative history. Language is a social invention, and thus meaningless without access to those external sources, such as dictionaries, that explain the rules as to how a particular language is used. It does not follow from this, however, that alt social interactions contemporaneous with the adoption of a law are equally helpful in shedding light on the original public meaning of the words of that law. The best places to find that public meaning are sources that would have been available to the Framers or that reflect the Framers' usage.

36. BORK, supra note 31, at 145; see also PERRY, supra note 31, at 31-53 (endorsing originalism with respect to constitutional text). Smith, supra note 13 , provides a particularly compelling explanation of the argument as to why enacted constitutional and statutory legal writings should be given their original meaning.

37. Consider in this context Bork's explanation of why he disagrees with the judicial philosophy of the second Justice Harlan. The issue is whether unwritten historical traditions may rise to the level of constitutional law or whether it is only the constitutional text, as historically understood, that deserves that status. Bork explains:

The Constitution . . . is intended to check today's majorities, and it seems quite odd to check them with ... yesterday's majorities. I can think of no reason that rises to the level of constitutional argument why today's majority may not decide that it wants to depart from the tradition left by a majority now buried. Laws made by those people bind us, but it is preposterous to say that their unenacted opinions do.

BORK, supra note 31, at 235 (citing JOHN HART ELY, DEMOCRACY AND DISTRUST 62 (1980)) (footnote omitted).

38. See, e.g., Akhil Reed Amar, Article III and the Judiciary Act of 1789, 138 U. PA. L. REv. 1499 (1990).

39. BORK, supra note 31 , at $143-46$ (emphasizing first, primacy of law of text; second, public understanding of text; and discounting relevance of "[s]ecret reservations or intentions").

40. Something "seems invariably to get lost in excursions into the intent of the framers, namely that the most important datum bearing on what was intended is the constitutional language itself." JOHN HART ELY, DEMOCRACY AND DISTRUST 16 (1980). Although Ely is not an originalist, his views on the primacy of the text bear noting here.

41. Harmelin v. Michigan, 501 U.S. 957 (1991) (Scalia, J.); Scalia, supra note 11. Indeed, Justice Scalia has become well known for construing statutory texts, as well as constitutional texts, formalistically 
constitutional interpreters to look for the original meaning of the text in predictable places: (1) Consider the plain meaning of the words of the Constitution, remembering to construe them holistically ${ }^{32}$ in light of the entire document. (2) If the original meaning of the words remains ambiguous after one consults a dictionary and a grammar book, consider next any widely read explanatory statements made about them in public contemporaneously with their ratification. These might shed light on the original meaning that the text had to those who had the recognized political authority to ratify it into law."3 (3) If ambiguity persists, consider any privately made statements about the meaning of the text that were uttered or written prior to or contemporaneously with ratification into law. These statements might be relevant if, and only if, they reveal something about the original public meaning that the text had to those who had the recognized political authority to ratify it into law." (4) If ambiguity still persists, consider lastly any postenactment history or practice that might shed light on the original meaning the constitutional text had to those who wrote it into law. Such history is the least reliable source for recovering the original meaning of the law, but may in some instances help us recover the original understanding of an otherwise unfathomable and obscure text. $^{45}$

This is why, as Lessig and Sunstein concede, "originalists would approach [the question of whether or not a unitary Executive exists] through a (by now) standard formula [that considers] almost mechanically the key sources of interpretation, 'text, structure, and history,' as the basis for uncovering the Constitution's original meaning." 46 Indeed, they acknowledge that the hierarchy of originalist sources set out above "is quite likely to yield (for us) a very strong conception of the President's power." ${ }^{\prime \prime}$ Nonetheless, because of their "suspicion that much of the conventional reading of Article II's text

with an emphasis on the plain meaning of words and a rejection of legislauve hustones

42. On holism, see Akhil Reed Amar. A Neo-Federalist liew' of Aructe III Separaning the Two Tiers of Federal Jurisdiction, 65 B.U. L. Rev. 205. 242 \& n.125 (1985) |hereinafter Amar. A Neo-ficderalst View of Article III); Calabresi \& Rhodes, supra note 6. at 1215-16

43. Very briefly, that original meaning is deemed relevant because legal texts are "not just a collection of words" or markings on paper but are "rather the expression of a collective decision a decision made by the established political authority and expressed in a form recognized as confernng legal force and validity upon the decision." Smith, supra note 13, at 111. Onginalısm. unilke other interpreluve theones. prevents "the words of the enacted law" from being separaled from "the sourec of [their] authonty" $l d$

44. BORK, supra note 31, at 144: Kay. Adherence to the Original Intentions, supra note 31. at 273-81 (responding powerfully to commonly made criticism of onginalism); see $\mathrm{H}$ Jeffersun Powell. The Original Understanding of Original Intent, 98 HARV. L. REV. 885 (1985); sre also PteRRY, supra note 31, al $42-47$. Thomas B. McAffee. Reed Dickerson's Originalism-What It Contributes io Conicmporan Constuutional Debate, 16 S. ILL. U. L.J. 617, 647 (1992) (offering onginalist cntuque of Rabul Berger's focess on spectic. known intentions in construing "Exceptions Clause" of Arucle III)

45. Some non-originalists, of course. may give great weight to practuce over text, and may indeed regard the early "customs" under a text as telling us more about what "the lau" really is than does the text itself.

46. Lessig \& Sunstein, supra note 1 , at 12.

47. Id. 
is informed by very modern ideas" they openly admit that they "adopt a distinctive interpretive strategy." 48 Thus, "[r]ather than beginning with text or structure alone, [they] begin with history."49 Accordingly, they seek "to dislodge modern preconceptions about the nature of the President and executive power by contrasting these conceptions with those of the framers and with the actual theory and practice of the early Congress." 50

What this unfortunately means in practice is that Lessig and Sunstein seek the original legal meaning of the text of the Constitution not in the words themselves nor even in the publicly held understanding shared by the Framers and ratifiers. Instead, they seek that meaning in the postenactment behavior of the Congress, an institutional rival of the President from day one. We have several reasons for thinking that this "distinctive interpretive strategy" is completely "distinct" from, even alien to, the originalism they profess to adopt.

First, the premises of originalism do not allow a constitutional interpreter to go beyond the plain meaning of the words of the document itself (read holistically) unless there exists a textual ambiguity. The words, in context, are . law, and one does not consult the legislative history to a law unless it is needed to understand what the law meant objectively at the time it was enacted. If the text standing alone would have been clear to an ordinary user of the language at the time of enactment, one cannot consult the legislative history to that text in order to create an ambiguity. Legislative history should be used only to clarify linguistic ambiguity by shedding light on which of several possible textual meanings was in fact the one that was "intended."

This point holds with the greatest force for postenactment legislative history, which is the least reliable of all forms of "legislative" history. ${ }^{51}$ It is the least reliable form of legislative history precisely because there can be no guarantee that a later lawmaker's understanding in fact bears on the intent animating an earlier enactment. Postenactment legislative history thus has been denounced as "tricky and unreliable material at best" when it is used in statutory construction. ${ }^{52}$ But, if anything, it is much trickier and even more unreliable when used as Lessig and Sunstein have used it.

In their article, Lessig and Sunstein try to use the statutes of the first several Congresses to shed light on the understanding of those delegates to the state ratifying conventions who actually wrote the Constitution into law (even though they have not first demonstrated the existence of a textual ambiguity). Thus, they are in effect using the intentions of one lawmaking body (the First

48. Id. at 13 .

49. Id.

50. Id.

51. Criticism of the use of postenactment legislative history in statutory construction appears in William N. ESKRIDGE, JR. \& PHILIP P. FRICKEy, CASES AND MATERIALS ON LEGISLATION, STATUTES AND THE CREATION OF PUBLIC POLICY 757-59 (1988). We note that, properly speaking, postenactment history is not "legislative" at all. After enactment into law, there is no legislation, but only law.

52. Id. at 758 (quoting Judge Patricia Wald). 
Congress) to shed light on the original understanding of a text enacted by numerous prior lawmaking bodies (the state ratifying conventions), institutions that had very different memberships. ${ }^{53}$ This use of the First Congress' actions to shed light on the meaning of the Constitution is not without precedent (or justification) in constitutional law. But it is not analogous, as Lessig and Sunstein assert, to the use of the First Congress' actions to shed light on the meaning of the Bill of Rights. ${ }^{54}$ That is because the First Congress played a role in creating the Bill of Rights when it proposed the first ten amendments to the states, while it played no role whatsoever in creating the structural Constitution. ${ }^{55}$

To return to our first and main methodological point, we think Lessig and Sunstein's "distinctive interpretive strategy" violates the very premises of originalism. Accordingly, the conclusions they derive from the application of their "strategy" will not and should not persuade anyone who is an originalist or a textualist to give up on the unitary Executive. In effect, Lessig and Sunstein seek to create textual ambiguities about whether the Constitution establishes a unitary Executive by looking at the least reliable form of legislative history (postenactment), produced in this case by a body that is an institutional rival of the President. We find this unjustifiable because we do not agree, taking the Constitution as a whole, that there is any textual ambiguity about whether the Constitution creates a strongly unitary Executive. Put another way, we think it is as clear that the text of the Constitution, as it was originally understood, creates a unitary Executive as that it requires the President to be at least thirty-five years old.

We will defend this statement in Parts II and III below, but for now please accept it as a premise. In effect, what we think Lessig and Sunsiein have tried to do in their article is analogous to someone trying to prove that a very mature thirty-four-year-old could legally serve as President (despite the

53. To appreciate the different compositions of the First Congress and the ratifyulig conventions, one need only observe that there were 355 delegates to the Massachusetts ratifying consention alone. see 2 Tht

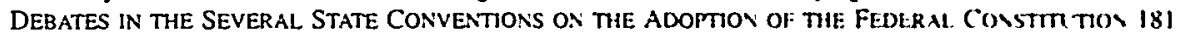
(photo. reprint 1987) (Jonathan Elliot ed.. New York. Bur Franklin. 2d ed 1888, lhereinafter Ei.1.10T's DEBATESl, a size far in excess of the number of Representauses and Senators in the Fint Congress

54. See Harmelin v. Michigan. 501 U.S. 957. 980 (1991) (examining actions of Fins Congress in analyzing Eighth Amendment); Marsh v. Chambers. 463 U.S 783. $788-90$ (1983) (examıning attuons of First Congress in analyzing Establishment Clause).

55. Obviously, many members of the First Congress were delegates to state ratify ing convenuons for to the Philadelphia Convention of 1787 that proposed the Constutution) it is for this reason that statements often appear about how the actions of the First Congress deserve special weight in analyses of the onginal. structural Constitution. But we must remember that all that is meant by those statements is that the constitutional understandings of the First Congress deserve more weight than thowe of the 100 th Congress As noted earlier, the First Congress did not approach representung all the Convention delegates Moreover. total deference to the first few Congresses would be highly inappropnate given their underrepresentation of key proponents of the Constitution. For example. three of the most significant Philadelphia contnbutors to the creation of the American presidency-James Wilson. Gouvemeur Mloms, and Alexander Hamilton-were not even part of the First Congress. See Akhil Reed Amar. Jurtsdiction Siripping and the Judiciary Act of 1789, in ORIGINS OF THE FEDERAL JUDICIARY 40, 62 (Miacia Miarcus cd . 1992) 
contrary language of the constitutional text), simply because some members of the First Congress may have thought that could happen some of the time. Our main response to such a claim is to say that the members of the First Congress were not infallible interpreters of the constitutional text. Is this really a claim with which Lessig and Sunstein want to disagree?

\section{B. The Source of Confusion Regarding Originalism}

Our second methodological point concerns how Lessig and Sunstein could come to think that their "distinctive interpretive strategy" would be received favorably by originalists. Here, we must say that we have some sympathy with what we perceive to be their plight.

The fact is that most originalist scholarship to date has addressed the problem of how to find the original meanings of constitutional provisions that everyone agrees are to some extent textually ambiguous, even after one has consulted a dictionary and a grammar book. For example, originalists have spent a lot of time trying to explain the original meaning of Section 1 of the Fourteenth Amendment and the original meaning of the various clauses in the First Amendment. ${ }^{56}$ This effort has been necessary because there is a range of genuine textual ambiguity about the original meaning of such phrases as "due process of law," "privileges or immunities of citizenship," "equal protection of the laws," "the freedom of speech, or of the press," "respecting an establishment of religion," and "prohibiting the free exercise thereof."

Thus, the provisions that originalists have tended to write about in recent times have happened to be almost without exception the ones where the constitutional text, read alone, can give only incomplete answers as to the original understanding. The originalist inquiry, then, has usually been pushed back from purely textual arguments to arguments based on evidence from the Constitution's enactment and postenactment history. Sometimes the main historical evidence available has been only evidence of the least persuasive sort. We have in mind, of course, the often-unreliable evidence provided by posteriactment legislative history.

From this, it is easy to understand how Lessig and Sunstein would come to think originalism was at least often about history, making their nontextual

56. For two exceptionally thoughtful originalist analyses of Section 1 of the Fourteenth Amendment, see Akhil Reed Amar, The Bill of Rights and the Fourteenth Amendment, 101 YALE L.J. 1193 (1992); John Harrison, Reconstructing the Privileges or Immunities Clause, 101 YALE L.J. 1385 (1992). For superb originalist analyses of the Free Exercise Clause of the First Amenjment by two authors who disagrec, sce Philip A. Hamburger, A Constitutional Right of Religious Exemption: An Historical Perspective, 60 GEo. WASH. L. REv. 915 (1992); Michael W. McConnell, Free Exercise Revisionism and the Smith Decision, 57 U. CHI. L. REv. 1109 (1990); Michael W. McConnell, The Origins and Historical Understanding of Free Exercise of Religion, 103 HARV. L. REV. 1409 (1990).

57. Thus, to pick an example from among authors cited in the previous footnote. Professors McConnell and Hamburger reach strikingly different conclusions as to the original meaning of the Free Exercise Clause. 
"distinctive interpretive strategy" methodologically justifiable at least some of the time. The difficulty for them is that the provisions of the structural Constitution that underlie the theory of the unitary Executive are not as openended as the key clauses of the First and Fourteenth Amendments. As a result, originalist methodology works differently' (and more simply) in the Article II context. ${ }^{58}$

It is important to note. moreover, that the methodology of originalism that Lessig and Sunstein embrace would lead to perverse results in the First and Fourteenth Amendment contexts as well. If one were to focus on postenactment history, or evidence of practice, to the exclusion of all else, it would wrongly lead one to conclude that Plessy i: Ferguson was correctly decided and that the Alien and Sedition Acts were constitutional. In each of these instances, examination solely of post-ratification legislative history, or practices, would show the presence of at least some behavior by Congress that we have since come to understand was in violation of the law of the newly enacted constitutional provisions."

This is unsurprising, of course, because it is unlikely that law-breaking administrators and legislators would instantly stop all of their misconduct simply because the law of the Constitution (as expressed in its lext) had changed. It is possible that because the bodies that ratify constitutional text and the institutions that must abide by it are distinct, the latter may seck to skirt the Constitution's new limits on their power. Or, perhaps, legislators and executives often do not immediately grasp the full consequence of some momentous change in the fundamental law. For all of these reasons, it seems clear that those who wish to understand the meaning of a new constitutional text must start with the words of the text and then see what their public meaning was at the time they were ratified into law. It also explains why prominent originalists-including Justice Antonin Scalia, former Judge Robert Bork, Professors Akhil Amar, John Harrison. Richard Kay. Gary Lawson, Thomas McAffee. and Michael Perry-do not use the Lessig and Sunstein methodology of originalism. Lessig and Sunstein have inadvertently fallen into using what is in effect a strict intentionalist, nontextual caricature of originalism."

58. We acknowledge that Lessig and Sunsicin do not dgree with our clasm that the tert of Articie II unambiguously requires a strongly unitary Executwe Thus, the) feel able to discuss Antele II as if th were as open-textured as the Founcenth Amendment. In Parts II and III below. we weeh to how why we believe Lessig and Sunstein are wrong in this regard.

59. Examples of such congressional behwor include (1) the mantenance of segragated xhools in the District of Columbia, even after the adoption of the Foureenth Amendment and the approval by Congress at the end of Reconstruction: and (2) the approval by an carts Congress (and by President John Adams) of the Alien and Sedition Acts notwithstanding the unequivocal command of the First Amendment

60. In fairness to Lessig and Sunstein, we note that there are not many clear explanations of onginalist methodology. In addition. origunalists disagree somewhat amongut themselies on this questson. with Raoul Berger advocating a form of extreme intentionalism, not unlike Lessig and Sunstein's, while Justice Seaisa and Professor Harrison essentially advocate a form of nearly pure texlualsm Former Judge Bork and Professor McConnell follow a middle course. in our vicu. between the intentionalist and textualist extremes. Thus, while they are both textualısts. nether wholly cndorses the Scalta crusude aganst all forms 


\section{More on Whose Original Understanding Counts and Why}

Our final criticism of Lessig and Sunstein's form of originalism is their decision to give almost dispositive weight to the views of one party in the debate-Congress. Congress has obvious institutional reasons for wanting to limit the power of the President. Whatever the merits in other contexts of looking at the views of the First Congress (or succeeding Congresses), there is reason for special care here. The premises of originalism suggest that we should determine what the Constitution originally meant to the people, as represented in the state ratifying conventions, when it was enacted into law and not what it meant later on to one party to an institutional dispute.

Yet Lessig and Sunstein have not done this because they consistently ask us to embrace their renditions of congressional understandings of executive power. Lessig and Sunstein thus seem mistakenly to believe that the First Congress' enactments accurately reflect the Framers' views, and indeed, they repeatedly equate the "First Congress" with the "Framers," sometimes even using the terms interchangeably. The premise underlying Lessig and Sunstein's approach is that relatively contemporaneous congressional actions are dispositive in interpreting new constitutional texts. A more appropriate survey of the postenactment history would include President Washington's views of his own power rather than the First Congress' views on the same subject. Yet even then had Washington declared himself to be King, we would not hesitate to say that the ex post views of an interested beneficiary (the President or Congress) of a contract (the Constitution) do not necessarily reflect "We the People's" original understanding of the meaning of that contract when it was enacted into law by the state ratifying conventions.

Our conclusion is that any sensible legislative history of executive power must begin by thoroughly addressing the original understanding during the framing and ratification periods, and only then must take up the postenactment views of President Washington (and his first few successors), the First Congress (and its successors), and the related views of any and all other constitutional interpreters who might have expressed an opinion. No preparer of legislative history would ever presume to rely solely on a partial account of the postenactment legislative history as derived from an interested source. Lessig and Sunstein's methodology of originalism leads them to misconstrue the constitutional text so that it can be made to fit their rendition of the

of legislative history.

Lessig and Sunstein, while not falling readily into any of these camps, seem to be closest to Berger. Berger's past writings, however, suggest that he would pay more attention to pre-ratification statements of the Framers and ratifiers and would put less emphasis on post-ratification congressional enactments. For an explanation of the difference between the "moderate intentionalism" originalism of a Scalia and the "strict intentionalism" originalism of a Berger, see PERRY, supra note 31, at 42-47. 
postenactment legislative history. ${ }^{61}$ The end result is not originalism but "congressionalism"- a wholly new interpretive theory based on the supremacy of after-the-fact congressional interpretations of the Constitution.

In Parts IV through VI, we present a more complete legislative history. But we stress that we do all of this quite grudgingly, and solely for the benefit of those not moved by our textualist arguments. We believe that the original meaning of the constitutional text unambiguously supports the unitary Executive, making such a historical excursion unnecessary. Originalism is first and foremost about the constitutional law that has been made by "We the People" and not about their history or practices or customs. As Judge Bork once said (in another context): "Laws made by (people now dead and buried may] bind us, but it is preposterous to say that their unenacted opinions do."

\section{The Textual Case for a Trinity of Powers and of Personnel}

We said above that the textual case for the theory of the unitary Executive is as free of ambiguity as the textual case that the President must be at least thirty-five years old. Our proof of this statement rests on the textual proposition that the Constitution recognizes the existence of only three kinds of federal governmental power and creates only three institutions of government. ${ }^{63}$ Our thesis that there exists only a trinity of powers (and of personnel) is essential to our conclusion that the executive department is strongly unitary.

We start by demonstrating that the Constitution creates only three types of governmental powers. We thus establish that Lessig and Sunstein cannot succeed in arguing for the constitutionality of an unvested, unenumerated.

61. Lessig and Sunstein concede that "In]o doubt there are umportant questions that can be rassed about the usefulness of post-enactment practice for interpreting the meaning of the Constitution " Lessig \& Sunstein, supra note 1 , at 13 n.47. Lessig and Sunstein go on to say that where "Congress's self-interest appears to be at stake?" as it was with the Alien and Sedition Acts. "we may disiount its conclustons" Id. Surprisingly, Lessig and Sunstein then clam that their article is really "not using pratice to prove a particular theory; [but] rather . . to raise doubts about a reigning. strongly unitanan theon " II Thus, they claim that all they really seek is "not the final history of the founding" but only to "jar current understandings by emphasizing the inconsistencies they produce." Id.

But the Lessig and Sunstein article is not merely a legal history prece. it is by its ou $n$ terms an arucie about what the Framers did or did not consututronalize. Incidentally. It is also about whether we (and ather originalist-unitarians) have propagated "myths." To assert in a lone foolnote that thetr article is really only about "using ... practice to raise doubts" or "to jar current understandings" about legal history. td. is confusing at best.

62. BORK, supra note 31, at 235.

63. We thus dispute Lessig and Sunstein's claum that the Framers did not understand "the terms 'executive' or 'legislative' or 'judicial' as describing fully developed calcgones that carne up the world of governmental power without remainder, as if governmental power were the genus. and executwe. legislative, or judicial were the only species." Lessig \& Sunstein. supra note I. at 41 We shall argue that the Framers were "budding constitutional formalists," id, and that they urote a text that canes up the world of government power into legislative. executive, and judicial power without remasnder Other types of govemmental power may well exist, but our federal govemment does not possess them 
fourth "administrative" power of government. ${ }^{64}$ In Section B, we make clear that Lessig and Sunstein's case for unenumerated governmental powers is far less plausible than is the (very controversial) case for unenumerated individual rights. In Section C, we attempt to show that the Oaths Clause and other provisions of the constitutional text make it clear that our Constitution contemplates only a trinity of governmental powers and institutions staffed by a trinity of types of personnel. Finally, in Section D, we show that any apparent residuum of powers or of types of personnel falls under the President's domain. We believe that the text of the Constitution unambiguously forecloses Lessig and Sunstein's historical argument for an unvested, unenumerated, fourth "administrative" power of government, to be apportioned by Congress, and to be exercised by "administrative" officers.

\section{A. The Constitutional Text: An Exclusive Trinity of Powers}

We begin by noting that Lessig and Sunstein do not agree with us that the relevant provisions of the constitutional text are unambiguous. They implicitly endorse two propositions. First, the constitutional text is ambiguous in its recognition of only a trinity of governmental powers (legislative, executive, and judicial). Thus, they think it permissible to make a historical argument that the Framers believed in the existence of a fourth administrative power of government-which Congress could vest in various entities pursuant to the Necessary and Proper Clause. ${ }^{65}$ Second, the text is ambiguous as to whether the President's "executive power" necessarily includes the whole universe of federal governmental powers that are not congressional or judicial. Thus, they deny that the President has a strong power of command and control over "administrative" entities that Congress chooses to set up. ${ }^{66}$

Is it really clear that the constitutional text is unambiguous in its recognition of only three types of governmental power? Remember that our burden of proof here is arguably very high. If there is any textual ambiguity whatsoever, Lessig and Sunstein could plausibly claim that they are justified in at least consulting the constitutional legislative history. ${ }^{67}$ It is not enough, therefore, to note that the constitutional text begins with three articles that list three, and only three, powers of government. We must prove as well that this

64. By administrative power, Lessig and Sunstein mean the power to carry into execution (or to administer) those powers of Congress found in Article I and elsewhere. See id. at 45-46. Thus, when Congress vests administrative power over postal affairs in an officer, that officer then has the authority to execute the nation's postal laws.

65. Recall that an analysis of text and structure alone would lead Lessig and Sunstein to endorse the unitary Executive thesis. Id. at 12. Their analysis of history, however, leads them to endorse an administrative/executive distinction. Accordingly, it is their reliance on history that causes them to think a textual ambiguity exists where we see none.

66. Id. at 12 .

67. For the only work on standards of proof for questions of legal interpretation, see Gary Lawson. Proving the Law, 86 Nw. U. L. REv. 859 (1992). 
list of three is an exclusive list. Put another way, we must prove that the maxim expressio unius est exclusio alterius applies.

How can we possibly know (unambiguously) whether the maxim applies? First, consider what the constitutional text itself says explicitly about this question. There is, after all, a provision that addresses the malter. The Tenth Amendment provides:

The powers not delegated to the United States by the Constitution, nor prohibited by it to the States, are reserved to the States respectively, or to the people. ${ }^{68}$

This means (among other things) that if the Constitution delegates to the federal government certain enumerated legislative powers, and the executive and judicial powers, but does not delegate the "administrative power," that power, if it exists, is reserved to the states or to the people." The message of the Tenth Amendment is that expressio umius est exclusio alterius applies to lists of governmental powers. All powers not delegated to the federal

68. U.S. CONST. amend. X.

69. A thoughtful but critical reader might at this point interject that the Tenth Amendment on its face appears to apply not to types of power (the Framers obviously conceived of only three-the document does not contemplate other types) but rather to spectfic enumerated powers (the power to create a Post Office. for example).

Such a claim, however, creates a false dichotomy between types of power and specifically enumerated powers and also misunderstands the nature of the executive and judictal power grants First. the idea that there is an inherent typology of governmental powers is false. since each of the three traditional categones of powers derives virtually all of its content either from histoncal expenence or from other more specific powers that our Constitution assigns to each of the three branches. Put more simply. "The executuve Pou er." for example, is probably not so much a type of power as it is a grab bag of many specifically enumerated powers, all of which we think of as belonging to the Executive, esther because they always did so belong in English and American history, or because the Constutution specifically assigns them to the Prestdent Similarly, "the judicial Power" and the "legislative Power" are also probably collectuons of specifically enumerated powers assigned by history or by the constitutional text to one branch or another.

This is illustrated by the extent to which our govemment is one of consututionally shared as uell as separated powers. Remember that our Chief Executive Officer. the President, possesses the "Iegislative" prerogative of the veto, while one of our two legislauve bodies. the Senale. shares in the "excculive" powers of appointment and treatymaking and in the "judicial" power of tring impeachment cases The point is that there is no meaningful distinction between typologies of power and specifically enumeraled powers: All of the three apparent typologies of power tum out to be histoncal and textual bundles of specifically enumerated powers, once one studies them closely enough.

Key members of the founding generation recognized and explanned publicly the truth of these points For example, James Madison, in his defense in The Federalist of our system of constitutionally separated and shared powers, made it clear that he did not believe that the politueal selence of his day had suceeeded in identifying the "platonic" content of the three types of governmental power THE FEDERALIST No 37, at 228 (James Madison) (Clinton Rossiter ed., 1961). He thus defended the Consutution agaunst the charge that it intermingled "types" of power in violation of Montesquicu's teachings by arguing that this was both inevitable, given the lack of inherent content to the "types." and a good thing because of the wisdom of checks and balances. Madison's defense of these points in The Federalist was widely read and is pan of the very core of his contribution to that justly celebrated collection of essays.

Moreover, for purposes of our argument here the language of the Tenth Amendment refers to "The powers not delegated by this Constitution." It makes no distunction between types of power and spectically enumerated grants of power. This is because no such distinction can be made. as will become evident in Part III below when we set forth our argument that the Vesting Clauses of Articles II and III must be understood as being power grants. See infra part III.A. 
government by the Constitution are reserved to the states or to the people. The amended text expressly precludes the existence of unenumerated, or inherent, powers of government. ${ }^{70}$

At this point, a critical reader might ask why we place so much weight on the Tenth Amendment when we know, as many distinguished scholars and jurists have taught us, that the Amendment states only a "truism"11 that is now, once again, "happily" nonjusticiable. ${ }^{72}$ Can the Tenth Amendment be relied upon alone to prove that the trinity of governmental powers is an exclusive list?

The answer is that while the Amendment adds nothing to what is already in the Constitution, and is thus a "truism," the truth that it restates is itself fatal to the Lessig and Sunstein thesis. Put more simply, we do not need the Tenth Amendment alone to tell us that the listing of governmental powers in the text of the Constitution is an exclusive list. This fact is self-evident from even a cursory examination of the unamended document itself. Several aspects of that unamended document make it clear that the governmental powers it lists are subject to the expressio unius est exclusio alterius maxim.

First, it is noteworthy that the various lists of governmental powers in the Constitution are long and detailed. The very length and detail of these lists make it far more likely that they were intended to be exclusive lists rather than exemplary ones. After all, why else would the Framers have carefully listed and set forth eighteen powers of Congress in Article 1 , Section $8{ }^{73}$ eleven powers of the President in Article $\mathrm{II},{ }^{74}$ and nine categories of federal court jurisdiction in Article III, ${ }^{75}$ if those lists were not meant to be exclusive ones subject to the maxim of expressio unius est exclusio alterius? It would make no sense for governmental powers to be so carefully enumerated and cabined wherever they were mentioned in the constitutional text unless the lists of governmental powers set forth were meant to be exclusive. Why would any reasonable drafter bother to mention that Congress had the "Power... To

70. Richard Kay points out that in Madison's original draft of the Bill of Rights, the Tenth Amendment did not immediately follow the Ninth. Rather, an amendment explicitly constitutionalizing the separation of powers came between them. That amendment was ultimately not adopted. Professor Kay speculates that the Tenth Amendment was thus not originally duplicative of the Ninth (cven though he reads them as redundant today) because the Tenth was needed to reiterate the principle that no unenumerated powers exist notwithstanding the failed separation-of-powers amendment's references to the existence of the legislative, executive, and judicial powers. Kay, Adherence to the Original Intentions, supra note 31 , at 271-72. This supports the point made in the previous footnote that the Framers understood the Tenth Amendment to apply to types of powers as well as to specific grants of powers.

71. United States v. Darby, 312 U.S. 100, 124 (1941).

72. Garcia v. San Antonio Metro. Transit Auth., 469 U.S. 528, 547-57 (1985). But see New York v. United States, 112 S. Ct. 2408, 2419-25 (1992).

73. U.S. CONST. art. $1, \S 8$, cls. $1-18$.

74. Id. art. II, $\$ 2$.

75. Id. art. III, § 2 . 
establish Post Offices and post Roads," ${ }^{76}$ while neglecting to mention something as important as a fourth type of government power? ${ }^{77}$

Second, there are some additional signals in the original text that strongly suggest the applicability of expressio unius est exclusio alterius. Consider three arguably exclusive constitutional lists. The first is the list of legislative powers "herein granted" to Congress, described in Article I (and elsewhere in the document). The second is the list of executive powers conferred on the President, described in Sections 1,2, and 3 of Aricle II. And the third is the list of nine categories of cases or controversies to which the "judicial Power [of the United States] shall extend," described in Section 2 of Article III. What, if anything, can be said about the applicability to these three lists of the expressio unius est exclusio alterius maxim?

The maxim most clearly seems to apply to lists one and three. ${ }^{\mathrm{x}}$ We know that the list of legislative powers conferred on Congress is an exclusive list because the Vesting Clause of Article I expressly tells us that Congress possesses only those legislative powers that are "herein granted." Similarly, we know that the list of cases or controversies in Article III is an exclusive list because those are the only ones (according to the Article) to which the "judicial Power shall extend." 80 The hard question then is whether the list (in Article II) of presidential powers is or is not exclusive. Commentators from Alexander Hamilton ${ }^{81}$ to Charles Thach ${ }^{82}$ to William Howard Taft ${ }^{83}$ to Professor Stephen Carter ${ }^{84}$ have all observed that the difference in language used to introduce the various lists strongly suggests that the Article II list is less obviously an exclusive list than its Article I counterpart. Those who agree may well believe that there exists a textual warrant for inherent, unenumerated executive powers. ${ }^{85}$

Our point here is not to prove or disprove the applicability of expressio unius est exclusio alterius to the Article II list but rather to emphasize that the maxim self-evidently applies at least to the lists in Articles I and III. It

76. Id. art. $\mathrm{I}, \S 8$. cl. 7 .

77. This point holds true even if one rejects the argument that the Tenth Amendment applies both to types of governmental powers and to specifically enumerated grants of govemmental powers If such a distinction existed, it would be unimaginable that the Framers would carefully desenbe three types of powers and all the specific grants that they encompassed, while neglecting to mention something as important as the existence of a fourth type.

78. See Calabresi \& Rhodes, supra note 6, al $1194-99$

79. U.S. CONST. an. I. $\S$ I. cl. 1.

80. Id. an. III, § 2, cl. I. $1851)$.

81. 7 THE WORKS OF ALEXANDER HAMILTON 80-81 (John C Hamilion ed. New Yorh. John F Trou

82. Charles C. Thach Jr., The Creation of the: Presidevey 1775-1789, al 138 (1923)

83. Myers v. United States, 272 U.S. 52. 118 (1926)

84. Carter, supra note 4 , at 115 n. 37.

85. We personally do not believe in the existence of an inherent. unenumeraled executwe power to act contra legem by seizing steel mills. For a descnption of what it means to act contra lesem, see Monaghan, supra note 6, at 10-11. 
arguably may also apply to the list in Article II.$^{86}$ Given all of this, what, if anything, can we deduce about whether the maxim applies to another and even more basic list? Does it apply to the list of three kinds of governmental powers implicit in the Vesting Clauses of Articles I, II, and III?

We think the answer is plainly yes. Assume the Article I and Article III lists are exclusive lists by their own terms, as we have argued above. Would it not then be bizarre for someone to argue that the (trinity of powers) Vesting Clause list was not also an exclusive list? What could move anyone to draft a document that carefully constrained federal legislative and federal judicial powers (and arguably constrained federal executive power as well), but that left unenumerated and unchecked something as important as a fourth power of government, i.e., a federal administrative power? The text of the Constitution simply cannot be construed to recognize more than the three traditional powers of government. The listed trinity of governmental powers is unambiguously an exclusive list. ${ }^{87}$

\section{B. The Textual Case for Unenumerated Powers of Government Is Much Harder To Make than the Case for Unenumerated Individual Rights}

At this point, a critical reader might legitimately ask, "Why should we read the Constitution as precluding the existence of unenumerated, or inherent, powers of government when many (if not most) of us do read the Constitution to recognize the existence of unenumerated, or inherent, individual rights?" 88 The answer is found in an express constitutional provision. The Ninth Amendment may send a very different message than the Tenth about the applicability of expressio unius est exclusio alterius to the list of rights found in the Bill of Rights. The Ninth Amendment provides that:

The enumeration in the Constitution, of certain rights, shall not be construed to deny or disparage others retained by the people. ${ }^{89}$

It seems possible that the Ninth and Tenth Amendments, when read together, may send conflicting (but philosophically harmonious) messages about the applicability of the maxim expressio unius to constitutional lists. Taken together, they say that there are no unenumerated, inherent powers of government, but there may be unenumerated, inherent individual rights. In

86. For a concise and powerful explanation of why the Article II list is probably not airtight and exclusive, see id. at $20-24$.

87. A substantial body of pre-1787 historical materials and documents provides support for the textual argument in this Section. See infra part V.

88. See, e.g., Roe v. Wade, 410 U.S. 113 (1973); Griswold v. Connecticut, 381 U.S. 479 (1965),

89. U.S. CONST. amend. IX. 
other words, apply the maxim to lists of governmental powers, but do not apply it to lists of individual rights. ${ }^{90}$

For those who believe that the Framers endorsed a Lockean, individualistic philosophy of government, ${ }^{91}$ this message should not seem surprising. Belief in unenumerated individual rights would likely coexist with a jealous skepticism about (and hostility to) the existence of unenumerated, inherent powers of government. Thus it would make sense for a written Constitution to come loaded with unenumerated rights, while denying the existence of unenumerated governmental powers. But Lessig and Sunstein's written Constitution comes loaded (presumably) with borh unenumerated rights and unenumerated governmental powers. Any such document was badly drafted indeed.

In our judgment, these considerations may help shed light on why American constitutionalism has historically been skeptical of various claims arguing for unenumerated (or inherent) governmental powers. ${ }^{92}$ Certainly, such skepticism has always greeted the claims made by several of our Presidents that there exist unenumerated and inherent "executive powers" to act contra legem. ${ }^{93}$ Indeed, Lessig and Sunstein make clear that they are themselves skeptical of such claims of unenumerated "inherent" executive power. ${ }^{94}$ At the same time, they argue for the existence of a fourth unenumerated power of government. We do not see how Lessig and Sunstein can deny the existence of one while recognizing the existence of the other.

90. We use the qualifier "may" in this paragraph because we do not wish in this already lengthy Article to get dragged into the great debate over the original meaning of the Ninth Amendment. Compare Kay, Adherence to the Original lntentions, supra note 31, at 269-73 (arguing that "[t]he ninth amendment's protection of retained rights ... implies only a limited reading of federal powers") and Thomas B. McAffee, The Original Meaning of the Ninth Amendment. 90 COLUM. L. REv. 1215 (1990) (arguing that Ninth Amendment protects "residual rights" and is "designed to preserve the scheme of limited powers for securing interests that include, but are not necessarily limited to. (raditional sors of individual nghts") with Randy E. Barnett, Foreword: The Ninth Amendment and Constutuonal Legutmacy, 64 CII.-KENT L. REV. 37 (1988) (questioning "whether the power constraints conception is the best of the available interpretalions of the Ninth Amendment"). See generally Gary Lawson \& Patricia B. Granger. The "Proper" Scope of Federal Power: A Jurisdictional Interpretation of the Sweeping Clause, 43 DUKE L.J. 267, 326-30 (1993) (showing how Necessary and Proper Clause bears on Ninth Amendment debate). Suffice tt to say that even if there are judicially enforceable unenumerated rights. per the Ninth Amendment. the Tenth Amendment makes clear that there are no unenumerated powers of government.

91. See, e.g., Suzanna Sherry, The Founders' Unwriten Consutution. 54 U. CuI. L. REV. 1127 (1987).

92. Consider the wise rejection by our federal courts of the notion that they might have an inherent power to enforce common law crimes, United States v. Coolıdge. 14 U.S. (I Wheat.) 415 (1816): United States v. Hudson \& Goodwin. 11 U.S. (7 Cranch) 32 (1812), or to "make" federal common law. Swift v. Tyson, 41 U.S. (16 Pet.) I (1842), overruled by. Erie R.R. v. Tompkins. 304 U.S. 64 (1938).

93. See, e.g., Train v. City of New York. 420 U.S. 35, $46-49$ (1975) (rejecting inherent executuve power to impound funds in contravention of appropriations statute): sec also Calabresi \& Rhodes, supro note 6, at 1177 n.119 (rejecting claims of inherent executive power to act contra legem); Minaghan, supra note 6, at 24-32 (explaining and rejecting notion that President has power to act contra legem): Redish \& Cisar, supra note 6, at 983-85 (rejecting presidential claims of "inherent" powers).

94. See Lessig \& Sunstein, supra note 1, at 2. 118-19. 


\section{Three Types of Institutions and Personnel}

We have seen that the constitutional text does not permit historical arguments for the existence of a fourth inherent, unenumerated administrative power of government. We shall now demonstrate that it also contemplates only three types of institutions of government staffed by three types of personnel. The Tenth Amendment will not help us here since it speaks only to the nonexistence of unenumerated powers and does not address the existence of a "fourth branch" or a fourth type of personnel. But the expressio unius est exclusio alterius maxim does apply and unambiguously rules out such arguments.

The question that Lessig and Sunstein's analysis implicitly raises is whether the existence of a fourth, administrative branch of government is foreclosed by the Constitution's textually explicit creation of the Congress, the presidency, and the federal judiciary. A cursory glance at the seven articles of the structural Constitution suggests an answer: Only the three specifically named branches are allowed. Indeed, each of the first three articles ordains and establishes one branch or institution and then very carefully describes how its officers are to be selected and what powers they are to have. After those first three articles, we find one article dealing with the states (Article IV), one concerning the procedures for amending the Constitution (Article V), one regarding adoption of the Constitution itself (Article VII), and one article pertaining to important but unrelated items like assumption of Confederation debts, the supremacy of federal law, and an obligation that state and federal officers take an oath of allegiance to the federal Constitution (Article VI). The specificity of these articles forecloses the argument that expressio unius est exclusio alterius might not apply, at least to the listing of the three branches. We see no textual clues that suggest the listing of the three branches was meant to be an "exemplary" rather than an exclusive list."

Lessig and Sunstein claim, however, that the text of the Constitution does contemplate a distinction between executive departments that are under the President's direction and administrative departments that are not. They note that the Constitution only permits the President to command opinions from the principal officers of the executive departments. ${ }^{96}$ At the same time, they observe that the Inferior Officers Appointments Clause gives Congress the power to vest appointment authority in officers described only as "Heads of Departments." The lack of the adjective "executive" before the word

95. We do, however, note two institutions outside the three branches that were designed to channel popular participation in government: the electoral college established in Article II, U.S. CONST. art. II. $\$ 1$. cl. 2, and the constitutional convention envisioned in Article V. These two institutions appear to be the only other federal institutions contemplated by the Constitution.

96. Id. art. II, § 2, cl. I.

97. Id. art. II, $\S 2$, cl. 2. 
"Departments" in the latter Clause suggests to Lessig and Sunstein that the Constitution might distinguish between at least two types of departments, one executive, the other not.

While we favor close attention to the constitutional text, this argument elevates a trivial textual distinction and builds a whole theory of American government upon it in a way that is utterly implausible. The Framers' text carefully describes the mode of selection, the term of office, and the salary guarantees of the President, the members of Congress, and all federal judges, as well as enumerating the powers that would appertain to each of these officers and their institutions. When questions were punted to Congress and to future generations, such as the question of whether to set up inferior federal courts, the text was likewise explicit about the "punting." Accordingly, we think it is highly unlikely that the Framers intended to permit Congress to conjure up an independent administrative branch of government in so elliptical a way. The differences in wording to which Lessig and Sunstein point are of no significance, just as the slight variations in wording between the two clauses that vest Congress with the power to create inferior courts to the Supreme Court have no significance. ${ }^{98}$ It should therefore come as no surprise that after pointing out the existence of these distinctions, Lessig and Sunstein admit that they "do not want to make too much of [them]."

But there are other reasons why we think that the constitutional text does not permit the creation of nonexecutive, administrative departments. Consider first the Oaths or Affirmations Clause of Article VI, which explicitly refers to, and clearly contemplates, only three types of federal officers or personnel. Let us begin with the plain language of the Clause: "The Senators and Representatives before mentioned, and the Members of the several State Legislatures, and all executive and judicial Officers, both of the United States and of the several States, shall be bound by Oath or Affirmation, to support this Constitution ...."100 This Clause suggests that, contrary to Lessig and Sunstein's core thesis, no independent federal administrative officers were ever contemplated by the Framers of the Constitution. That document only contemplates and describes three types of federal officials: members of Congress, executive officers, and judicial officers. If Congress could vest administrative power in individuals who were neither members of Congress nor executive or judicial officers, the Oaths or Affirmations Clause would not apply to these administrative officers. Yet, it is absurd to conclude that the Constitution requires oaths of members of Congress and of executive and judicial officers, but that it does not require oaths from federal administrative

98. Compare id. art. I, $\& 8, \mathrm{cl} .9$ (Congress has power "(1) construte Tnbunals infenor to the supreme Cour") (emphasis added) with id. art. III, $\$ 1$ ("judicial Power" vested "In such infenor Courts as the Congress may from time to time ordain and establish") (emphasis added).

99. Lessig \& Sunstein. supra note 1. at 38.

100. U.S. CONST. art. VI, cl. 3 (emphasis added) 
officers. Lessig and Sunstein apparently would have us believe that the Framers meant to require Secretary of State Jefferson and Representative Madison to take an oath to support the Constitution while absolving Alexander Hamilton of the same obligation. ${ }^{101}$

Consider second that the Constitution repeatedly refers to federal and state executive $^{102}$ and judicial officers, ${ }^{103}$ and to federal and state legislators (or to state legislatures more generally). ${ }^{104}$ But the hard fact is that the constitutional text nowhere mentions administrative officers, or any other categories of personnel beyond the legislative, executive, and judicial types. Add to this the fact that the Constitution implicitly assumes that state governments are also staffed by only these three types of personnel and the point seems proved.

The Constitution makes no reference to any administrative branch of government, nor to any administrative officers, even though it is filled with references to legislative, executive, and judicial institutions and officers, because the people who wrote the Constitution did not envision a separate category of "administrative" institutions or officers. Once again, that category is revealed to be "a creation of the twentieth century, not the eighteenth." 105

\section{Why the Constitutional Trinity Leads to a Strongly Unitary Executive}

We have now seen that the constitutional text unambiguously creates an exclusive trinity of powers, of institutions, and of personnel. It remains for us to consider the implications of this for the second of the two questions put forth in Section A of this Part: Does Article II's vesting of the President with

101. Recall that under Lessig and Sunstein's theory, the Secretary of the Treasury. Alexander Hamilton, was not an executive officer but was instead an administrative officer. Their theory secms also to run counter to the logical implications of the first statute passed by the First Congress, which construed the Oaths or Affirmation Clause of Article VI to require "[t]hat all officers appointed ... under the authority of the United States" take an oath or affirmation of allegiance to the Constitution. Act of June 1, 1789, ch. 1, §4, 1 Stat. 23, 23-24.

102. See, e.g., U.S. CONST. art. $1, \$ 2, \mathrm{cl} .4$ (noting that when vacancy in representation of state ariscs, "Executive Authority" may issue "Writs of Election" to fill such vacancies); id. art. I, § 3, cl. 2 (noting Executive's ability temporarily to appoint Senators where vacancies exist); id. art. IV, $\$ 2$, cl. 2 (noting that "executive Authority" of each state is bound to deliver up fugitives of justice from other states); id. art. IV, $\S 4$ (stating that Executive can apply for federal protection against domestic violence affecting state).

103. See id. art. I, § 3, cl. 6 (establishing that Chief Justice will preside over presidential impeachment trials); id. art. VI, cl. 2 (binding state judges to supreme law of land). We think that the term "judicial officers" in the Oaths Clause not only includes federal and state judges, but refers to all those statutorily charged with helping those judges discharge their powers and duties (such as clerks and other support personnel). If the Framers had only meant for the Clause to cover judges, that term, rather than "judicial officers," could have been used. Moreover, we think the existence of such inferior judicial officers is confirmed by the Constitution's vesting in Congress the ability to grant federal judges the power to appoint inferior judicial officers. See id. art. II, $\S 2, \mathrm{cl} .2$.

104. See, e.g., id. art. I, $\S 3$, cl. 2 (stating that when state legislature is in session, it appoints Senators to vacant Senate seats); id. art. II, $\$$ I, cl. 2 (granting state legislatures right to choose Electors for presidential electoral college); $i d$. art. IV, $\S 4$ (permitting state legislatures to apply for federal intervention against domestic violence).

105. Lessig \& Sunstein, supra note 1 , at 2. 
all of the "executive Power" give him control over all federal governmental powers that are neither legislative nor judicial?

The answer is unambiguously yes. The text makes clear that there will be three and only three types of powers, of institutions, and of personnel. Accordingly, the scattered allusions that Lessig and Sunstein have found to the existence of an "administrative power," or to the existence of administrative personnel, must somehow be made to fit subordinately into the Constitution's trinitarian framework. We think we know where in that framework the "administrative power" and the administrative personnel must fit.

Any administrative power or personnel that exists cannot be derivative of or subordinate to the legislative power or the judicial power. Those powers cannot be delegated, even to administrative officers, and administration requires the delegation of power to numerous officials. ${ }^{106}$ Moreover, administration cannot be conducted through the procedural hoops that the Constitution imposes on all exercises of legislative and judicial power. It would be impractical to "administer" anything subject to procedural constraints of bicameralism, presentment, or the existence of a case or controversy. ${ }^{107}$ If the mechanisms for the use of the legislative and judicial powers are simply unsuitable for employment of the administrative power, only one other constitutional actor remains. The administrative power, if it exists, must be a subset of the President's "executive Power" and not of one of the other two traditional powers of government. ${ }^{108}$

The important point here is that once history's grab bag of assorted enumerated powers is run through the Constitution's trinitarian "funnel," the

106. Mistretta v. United States, 488 U.S. 361. 424-25 (1989) (Scalız, J., dissenung): 2 Axwals of CONG. 712 (1792) (statement of Rep. Findley) ("[I]t is of the nature of Executuve power to be transferable to subordinate officers; but legislative authority is incommunicable, and cannol be (ransferred."). Lawson. supra note 6 , at 1243 n.72.

107. See Harold J. Krent, Separating the Strands in Separation of Poviers Controverstes. 74 VA. L. REV. 1253 (1988); Merrill, supra note 6.

One might argue that Congress does not need bicameralism and presentment in certan exercises of legislative power. See, e.g., U.S. CONST. ant. I. \$2, cl. $5 \& \$ 3 . \mathrm{cl} .5$ (stalıng that House and Senate have authority to appoint congressional officers): $t d$. an. 1 . $\$ 5$ (permitung each chamber to judge electuons of its own members, to adopt rules, and to keep journals of proceedings). Simularly. one could aiso contend that federal judges do not need a case or controversy to act, since Congress can vest them with appointment authority. See id. art. II, \$2, ci. 2. We view these exercises of powers as limited. textual exceptions to the general rule that Congress acts through bicameralism/presentment and the judiciary through cases or controversies.

108. Professor Calabresi believes that it may be relevant in this regard that our analysis in Section A of this Part suggests that the President's enumerated list of constitutional powers is the least itkely of the three enumerated listings to have been meant to be exclusive. This is why Professor Henry Monaghan, after a thoughtful analysis. awards "the paim" to those who believe that any very limited residuum of governmental powers that may exist must belong of necessity to the President and to no one else, and must be encompassed textually within the Executive Power Clause. Monaghan, supra nole 6. at 20-24 Professor Monaghan explains powerfully that any executive residuum could not possibly include a power to act contra legem in violation of constitutionally valid statutes. Professor Calabresi agrees with this point and emphasizes that any constitutional residuum that exists is very limited in scope and reflects the faet that the President's powers are necessarily something of a historical grab bag of anomalies that could not be given to anyone else. 
President must end up with any administrative powers that otherwise cannot be accounted for. This is why we began this Part by saying that constitutional trinitarianism underlies our belief in strong executive unitarianism. By now, we believe we have shown that the textual case for a trinity of powers and of personnel is ironclad. It is as free of ambiguity as the textual case for the proposition that the President must be at least thirty-five years old.

\section{The Textual Case for the Unitary Executive}

In this Part, we seek to prove that the Constitution unambiguously gives the President the power to control the execution of all federal laws. We begin by showing in Section $A$ that the Executive Power Clause is not a mere designation of office but is a grant of power to the President. In Section B, we continue the argument by showing that the Clause's grant of power to the President is exclusive, not concurrent, and that it thus prevents Congress from ever making the administration independent of presidential control. In Section $C$, we argue that the Take Care and the Opinions in Writing Clauses support rather than undermine the unitary Executive thesis. In Section D, we contend that hitherto-unnoticed provisions of the Constitution (namely the Militia Clauses) provide further evidence of the President's central role in federal law execution. In Section E, we attempt to show that the Necessary and Proper Clause does not vest Congress with any power to alter constitutional structure by statute. Congress may only use that Clause to assist itself and the other branches by providing the means for carrying into execution a power already possessed by a branch of the federal government. In Section F, we examine the means available to the President for controlling his subordinate executive officers. We sum up the textual analysis of Parts II and III in Section G. We conclude that the administrative power so emphasized by Lessig and Sunstein is nothing more than a part of the President's "executive Power" to execute federal law.

\section{A. The Vesting Clauses as Power Grants}

\section{The Analogy Between the Vesting Clauses of Article II and Article III}

There are many reasons why the Vesting Clause of Article II must be read as conferring a general grant of the "executive Power"-a grant that is in turn defined and limited by the later enumerations in Article II, Section 2. ${ }^{109}$ To begin with, the Clause is linguistically and structurally similar to the Vesting Clause of Article III (and different from the Vesting Clause of Article I). The

109. For a lengthier treatment of this point, see Calabresi \& Rhodes, supra notc 6 , at 1175-85, and the superb analysis in Monaghan, supra note 6, at 20-24, with which we heartily concur. 
Vesting Clauses of Articles II and III contain nearly identical language in parallel grammatical formulations. Both omit the "herein granted" qualification that appears in the Vesting Clause of Article I, and both confer general grants of power (executive or judicial) on federal governmental entities that are then defined and limited by later provisions of Aricles II and III.

The Vesting Clause of Article III is widely conceded to be a general grant of power to the federal judiciary; indeed, it is conceded to be the only textual constitutional source of the federal judiciary's authority to act. ${ }^{10}$ There are no other clauses that grant power to the federal judiciary in Article III, and there are not even any clauses that really define or constrain the Vesting Clause's general grant of the judicial power in the subsequent sections of that Article (with the vital and much-discussed exception of those clauses that grant Congress broad authority to withdraw the jurisdiction of the inferior courts and of the Supreme Court)."' Accordingly, it makes sense to read the analogously worded Vesting Clause of Article II to be a general grant of power given that its Article III counterpart must be so read. This construction is all the more compelled because both Vesting Clauses state that the respective powers they confer "shall be vested" rather than merely that those powers "may be vested." Substantial evidence exists that the Constitution is deliberate in its use of the mandatory word "shall" instead of the permissive word "may," and that it almost always uses "shall" when it means to impose a mandatory duty."

110. The only sustained argument in the legal academic literature of which we are aware is a recent article by Professor Michael Froomkin to which Professor Calabresi has wntlen a response. Compare Froomkin, New Vestments, supra note 5 with Steven G. Calabresi. The Vesting Clauses as Power Grants. 88 Nw. U. L. REV. 1377 (1994).

111. We make this claim because although Article III. Section 2 explains with greal spectficily which cases or controversies may be reached by the "judicial Power." 11 does nol even begin to altempt to answer the question of what the "judicial Power" is. Does it include an "inherent" power to issue equitable relief? To award money damages? To render declaratory judgments? To declare federal common law' Anicle III. Section 2 simply does not say. All we can discern from the text is that Artucle III. Section 1 confers a general grant of power, the exact extent of which is unclear.

It is vital to note, however, that Article III. Section 2 does grant Congress iwo imporzant powers that have been said to allow that body to constrain greatly the judicial power that is granted in general terms by the Article III Vesting Clause. Thus, Congress' power to create (or not to create) infenor federal courts has been said to include very broad power to regulate their junsdictuon and remedial authonty. Furthermore. Congress' (arguably broad) power to make exceptions to the Supreme Court's appellate jurisdiction has similarly been said to give it power to constrain the appellate jurisdiction and the remedial authonity of the Supreme Court. Whatever the scope of Congress" jurisdiction-stripping powers. It secms to us that the general grant of the "executive Power" in Article II. Section 1 is broader and less qualified by other grants of power to Congress than is the general grant of the "judicial Power" in Arucle III. Section I.

112. See. e.g., Amar, A Neo-Federalist View' of Aricle III. supra note 42. at 231-33 (arguing that "shall" means "must" as used in Vesting Clause of Article III): Calabresi \& Rhodes. supra note 6, at 1186-94 (arguing that "shall" means "must" as used in Vesting Clause of Article II if it means "must" as used in Vesting Clause of Article III); Rober N. Clinton. A Mandaton" View of Federal Court Jurusdiction: A Guided Quest for the Original Understanding of Article III. 132 U. PA. L. REV. 741. 748-49 (1984) (same). 
Moreover, as Professor Calabresi explains in his recent article, The Vesting Clauses as Power Grants, ${ }^{113}$ it is a truism under our Constitution that no government actor can take any action that affects the rights of private parties unless that action is somehow ultimately authorized by a grant of "power" from "We the People" that appears in the text of the Constitution. Thus we can presume that there must somewhere be a constitutional source of both the federal judiciary's and the President's authority to act. Many scholars to date have purported to find such a source for the President's power only in the specifically enumerated executive powers listed in Article II, Section 2. ${ }^{114}$ And, as we shall see below, Lessig and Sunstein reach essentially the same outcome through more clever means. But the important point for now is that this option is simply not available for the federal judiciary using the nine enumerated heads of jurisdiction in Article III, Section 2. For a variety of reasons, it is very difficult to maintain that the federal judiciary's constitutional power grant could somehow come from a Clause that reads, the "judicial Power shall extend to all Cases," rather than from a Clause that reads, the "judicial Power ... shall be vested in one supreme Court, and in such inferior Courts."115

\section{The Plain Meanings of the Verbs "Vest" and "Extend"}

Let us closely examine, then, the plain meanings of these two verbs. In its verb form, vest means "[t]o place in possession of" an individual or entity. ${ }^{116}$ It derives from the Latin word "vestis" for outer garment and is related to the word "vestments" (as in ecclesiastical vestments, the robes of church office). The word signifies the "clothing" of an official or of an institution with the

113. Calabresi, supra note 110 , at 1378-79.

114. Ledewitz, supra note 5, at 797; Rosenberg, supra note 5, at 634; Froomkin, Agency Altonomy, supra note 5, at 799-800 (arguing that if Vesting Clause alone were sufficient to confer exccutive power. Article Il would be only one sentence long); see also Charles L. Black, Jr., The Working Balance of the American Political Departments, 1 HASTINGS CONST. L.Q. 13, 14-15 (1974) (acknowledging some very limited power-grant role for Article II Vesting Clause but concluding that in truth President possesses only five or so significant constitutional powers).

115. Compare U.S. CONST. art. III, § 2 ("The judicial Power shall extend to all Cases ... .") with idl. art. III, $\S 1$ ("The judicial Power of the United States, shall be vested in one supreme Court, and in such inferior Courts as the Congress may from time to time ordain and establish.").

There is a second reason to think that only the Vesting Clause of Article III can serve as the constitutional source of the federal judiciary's authority to act. See Calabresi, supra note 110, at 1382-83. Any clause that is going to serve as a power grant simply must indicate who is being empowered. Put another way, there is both a "who" and a "what" to any constitutional provision that grants power. Such clauses must say both what power is being granted and to whom it is being granted.

This in turn dictates the conclusion that only the Article III Vesting Clause can serve as a constitutional power grant to the federal judiciary because only that Clause indicates who is being empowered. The nine heads of jurisdiction and the other subsequent provisions of Article III do not by themselves make clear who gets to exercise exclusively the powers and jurisdictions of which they speak. Only the Vesting Clause of Article III can play that role. $J d$.

116. 2 SAMUEL Johnson, A Dictionary of the ENGlish Language 2102 (Librairic du Liban ed. 1978) (4th ed. 1773) [hereinafter JOHNSON's DicTIONARY]. 
general trappings and realities of power. It survives today in this sense in the word "investiture," the ceremony whereby a judge (or a bishop) assumes both the robes and the powers of his office. The verb "to extend," however, has no such meaning. It derives from the Latin "extendere," meaning "to stretch [tendere] out [ex]" an already existing thing or, in this case, a power." The etymology and plain dictionary meaning of these words make clear that it is the verb "vest" in the Article III Vesting Clause that empowers the federal judiciary to act whereas the verb "extend" can carry no empowering meaning or connotation.

This plain dictionary meaning is confirmed by the use of the verb "vest" in other constitutional provisions to connote placing a power in the hands of a named actor. Thus, the Necessary and Proper Clause provides:

The Congress shall have Power .. . To make all Laws which shall be necessary and proper for carrying into Execution the foregoing Powers and all other Powers vested by this Constitution in the Government of the United States, or in any Department or Officer thereof. ${ }^{1 t s}$

The word "vest" as it is used here clearly refers to the empowerment of an institution. This use confirms our intuition that the Article II and Article III Vesting Clauses must be in some sense grants of "the executive" and "the judicial" power and not "inkblots" or mere designations of a title.

Consider what would happen if we applied the usual academic reading of the word "vest" as "inkblot"119 to the Necessary and Proper Clause. The Clause would then read as follows:

The Congress shall have Power .. To make all Laws which shall be necessary and proper for carrying into Execution the foregoing Powers and all other Powers! @ $\$ \% \%^{\wedge} \mathbb{*}^{*}$ by this Constitution in the Government of the United States, or in any Department or Officer thereof.

The Inferior Officers Appointments Clause, which also uses the word "vest," 120 would be a nullity as well. The point is that if the word "vest" means!@\# $\$ \%^{\wedge} \&^{*}$ as many Article II scholars suggest, ${ }^{121}$ instead of meaning "to clothe with the trappings and powers of office" as we contend, both the Necessary and Proper Clause and the Inferior Officers Appointments Clause

117. I id. at 696 .

118. U.S. CONST. art. I, $\$ 8, \mathrm{cl} .18$ (emphasis added).

119. See BORK, supra note 31. at 166 (discussing how judges should decide cases when confronting ambiguous language).

120. "[T]he Congress may by law vest the Appoiniment of such infenor Officers. as they think proper. in the President alone, in the Courts of Law, or in the Healds of Departments." U.S. CONST art. II. \$2, cl 2 .

121. This is, in effect, the view of the scholars clted supra note 11.4 
must be virtually read out of the Constitution. This conclusion, however, devastates the core thesis of those who would attack the theory of the unitary Executive because it is precisely those Clauses upon which most anti-unitarian scholars rely to justify their assertion that as an original matter Congress could create independent officers and entities. Erase the word "vest" in the Vesting Clauses and you must erase it in the other two Clauses as well. In that case, the constitutional text would empower no one to act in these areas: not the Congress, not the President, and not the courts. This is an absurd, and, happily, incorrect interpretation.

\section{There Is No Implicit "Herein Granted" in Article II's Vesting Clause}

Lessig and Sunstein attempt to escape this interpretive quandary by arguing that there is an implicit "herein granted" provision in the Vesting Clause of Article II. Thus, they claim that

the framers intended the Vesting Clause to vest constitutionally little more than the enumerated executive powers. It says who has the executive power; not what that power is, just as the Vesting Clause of Article I says who has the legislative power (a Congress), while section 8 says what that power is, and the Vesting Clause of Article III says who has the judicial power (one Supreme Court at least) while section 2 specifies to what that power "extend[s]."

Quoting Daniel Webster, they go on to say that "“[i]t is true, that the Constitution declares that the executive power shall be vested in the President; but the first question which then arises is, What is executive power?"'123

There are, however, numerous problems with this response. First, consider what happens if one reads an implicit "herein granted" provision into the Vesting Clause of Article III. Since Section 2 of that Article only tells us to which categories of cases or controversies the general grant of "the judicial Power" extends, the entire Article fails to make sense if there is an implicit "herein granted" limitation in Article III, Section 1. Put more simply, there are no other powers "herein granted" in Article III once we get beyond the Vesting Clause. Thus, it makes little sense to read an implicit "herein granted" limitation into the Article III Vesting Clause. Reasoning by analogy, it makes little sense to try to read such an implicit limitation into the analogous Article II Vesting Clause.

Second, as was explained above, a comparison of the constitutional lists in Article I, Section 8; Article II, Section 2; and Article III, Section 2, clearly

122. Lessig \& Sunstein, supra note 1, at $47-48$ (footnotes omitted).

123. Id. at 48 (quoting Daniel Webster, Speech in the Senate (Feb. 16, 1835), in 7 WRITINGS AND SPEECHES OF DANIEL WEBSTER 186 (nat'l ed. 1903)). 
reveals that the Article II list is the least likely candidate for application of the maxim expressio unius est exclusio alterius. ${ }^{2 s}$ Examination of the length of the lists, the language that introduces them, and the interrelationship of the subject matters listed suggests that the Article II list is the least likely to have been meant to be exclusive and the most likely to have been meant to be exemplary. In part because of these considerations, Professor Henry Monaghan has endorsed the notion that there is a very limited residuum of executive powers that the President possesses, which is reflected in the constitutional text by the incompleteness of the Article II, Section 2 enumeration. ${ }^{125}$

Lessig and Sunstein reject the concept of an executive residuum and simply declare the Article II list to be exclusive, without ever addressing the possibility that this list might instead be exemplary, and without acknowledging Professor Monaghan's recent article. ${ }^{126}$ This move of implying "herein granted" language into a Vesting Clause that lacks it is clever but wrong. The analogy to Article III, the possible exemplary nature of the Article II enumeration, and the much-remarked-upon ${ }^{127}$ plain language of the Article II Vesting Clause itself ${ }^{128}$ all make clear that the Clause confers a general grant of "the executive Power"129 that then obtains much of its definition and content from the exemplary enumerations that follow. ${ }^{130}$ Lessig and Sunstein have crossed the line from interpreting text to creating it.

124. See supra text accompanying notes 78-85.

125. Monaghan, supra note 6, at 20-24. Professor Monaghan argues persuasively that the President possesses a "Protective Power."

126. Oddly, Lessig and Sunstein at one point almost seem to acknowledge the existence of an executive residuum when they say. "As we conceive it, the framers iniended the Vesting Clause to vest constitutionally little more than the enumerated exccutive powers." Lessig \& Sunstein, supra note 1, at 47 (emphasis added).

127. See supra text accompanying notes $81-84$.

128. As Professor Peter Strauss has observed in quoting Charles Thach:

Both the legislative and the judicial powers are enumerated in the Constitution. the former by a reference to "Powers herein granted," the latter by a statement of what it "shall extend to." "[W]hether intentional or not, [the absence of any similar language from the Vestung Clause of Article II] admitted an interpretation of executive power which would give to the president a field of action much wider than that outlined by the enumerated powers."

Strauss, supra note 3, at 598 n.88 (quoting THACH, supra note 82, at 138-39). We agree with Professor Thach.

129. Lessig and Sunstein asser that the President has the constitutional authority to direct our nation's foreign affairs, yet it seems to us that the textual source of that authority can only be the Executive Power Clause. The President's power to receive ambassadors clearly does not encompass a general power to superintend foreign affairs. U.S. CONST. an. II. \& 3. The only other plausible textual source would have to be Article II, Section I. In rejecting our plain-meaning reading of the Vesting Clause, Lessig and Sunstein generate severe textual problems for their own executive/udministrative theory. Though Lessig and Sunstein never say what part of the Constitution grants the President the authority to direct foreign affairs, it appears that their view of his foreign affairs power is driven by their gaal of explaining the First Congress' creation of a Foreign Affairs Department under the exclusive control of the President. If the First Congress placed the Foreign Affairs Department under the President's direction. it must have done so because of its construction of the Constitution itself. It is a defect of the Lessig and Sunstein thesis that it provides no textual "hook" for a presidential foreign affairs power.

130. Calabresi \& Rhodes, supra note 6, at 1195-97. 
Finally, Lessig and Sunstein maintain that it is inappropriate to attach much importance to the presence of a "herein granted" provision in the Vesting Clause of Article I compared with its absence from the Vesting Clauses of Articles II and III. As they correctly point out, this phrase was added to the Constitution by the Committee on Style late in the Convention and without debate. These circumstances, they assert, suggest that the phrase had little effect. ${ }^{131}$ The short response to this is that the people who ratified the Constitution were not aware of this secret legislative history. Indeed, it did not become available until many years after the Constitution had been ratified into law. Since originalists maintain that it is the meaning of the text to the ratifiers that counts, they should give little weight to an antitextual argument derived from legislative history. Moreover, even if legislative history has some weight, the Committee on Style's insertion of the "herein granted" language actually supports our argument. Presumably, the change induced no debate or discussion precisely because it so thoroughly conformed to the Convention's understanding about the difference between the Article I and the Article II and III Vesting Clauses. In the face of clear text, Lessig and Sunstein's argument here from the absence of legislative history does not persuade. ${ }^{132}$

\section{Reading the Vesting Clause of Article II To Be a Power Grant Does Not Make the Rest of Article II Superfluous}

Lessig and Sunstein attempt to rebut the power-grant conception of the Article II Vesting Clause by claiming that such a construction would have "the effect of rendering superfluous much of the balance of Article II," ${ }^{133}$ since much of the remainder simply reiterates powers that are arguably granted by the Vesting Clause. To begin with, this critique applies with equal force to their theory of Article II. Lessig and Sunstein say that the Article II Vesting Clause is needed only to specify the Chief Executive's title (the "President") and to make clear that we have only one President. But we do not need the Article II Vesting Clause to tell us these things. They are self-evident from the remainder of the text of Section 2 of Article II, which repeatedly uses the words "[t]he President" and "he" to refer to what is obviously going to be one

131. Lessig \& Sunstein, supra note 1 , at $48-49$.

132. See id. at 49 n.204 ("We are here to apply the statute, not legislative history, and certainly not the absence of legislative history." (emphasis added) (quoting Chisom v. Roemer, 501 U.S. 380, 406 (1991) (Scalia, J., dissenting))); id. ("'In ascertaining the meaning of a statute, a court cannot, in the manner of Sherlock Holmes, pursue the theory of the dog that did not bark." (quoting Harrison v. PPG Indus., 446 U.S. 578, $592(1980))$ ).

Lessig and Sunstein cite other cases that do give weight to lacunae in statutory legislative histories and then argue that this Doyle canon of construction (so named for the inference drawn from Sherlock Holmes' famous dog that did not bark) is more applicable "in the context of the Constitution" because "so much is at stake." Id. at 49 n.204. We, of course, believe that the fact that so much is at stake counsels even more heavily against reliance on the absence of legislative history.

133. Id. at 48 . 
Chief Executive Officer with the title of President. ${ }^{134}$ Thus, if avoidance of redundancy is the key to constitutional interpretation, the "title and number" theory of Article II, Section I is as spurious as the power-grant theory we advance.

We do not believe, however, that avoiding redundancy should be a prime goal in interpreting the Constitution or other legal texts. ${ }^{135}$ This is because, as Justice Scalia has written, repetition is sometimes effective and deliberate. It may be used to add emphasis, or it may be employed out of an abundance of caution, lest anyone miss the significance of the message-" $e x$ abundanti cautela." ${ }^{36}$ In our view, Lessig and Sunstein worry too much (and too onesidedly) about potential redundancy in setting forth their construction of Article II.

But even if the avoidance of redundancy is really the key to constitutional interpretation, we still do not think that our power-grant theory makes the balance of that Article superfluous. As Professor Calabresi and Kevin Rhodes said two years ago in The Structural Constitution, "Articles II and III resemble each other and differ from Article I in that the first sections of both Articles confer somewhat nebulous grants of power on the executive and judicial departments, which the second sections of both Articles explicate and substantially qualify." 137 Calabresi and Rhodes explained that Section 2 of Article III does this by (1) limiting the range of cases that can be heard in federal rather than in state court to nine categories of cases or controversies; and by (2) giving Congress broad discretion over the existence, structure, and jurisdiction of the inferior courts and (arguably) over the appellate jurisdiction of the Supreme Court.

By the same token, Section 2 of Article II explicates and substantially qualifies the Vesting Clause's broad general grant of "the executive Power" by giving vital content to two extremely important constitutional boundarics: first, the boundary between the "executive Power" of the President and the "regal Power" of King George III; and, second, the boundary between the federal

134. If the Vesting Clause were a mere designation of office. as Lessig and Sunsteın believe. Article II would probably read as follows:

Section 1: All executive Powers of the Unted States herem granted shall be vested in a President of the United States.

Section 2: The executive Power shall extend so: the President's power to be Commander in Chief ....

Alternatively, a Vesting Clause that merely conferred a title might read like Article I of the Articles of Confederation, which provided: "The stile of this confederacy shall be. THE UNTEE STATES OF AMERICA." ARTS. OF CONFED. an. I. This does not sound much like Article II. Secuon 2 Interesungly. an early draft at the Philadelphia Convention had a naming clause for the chief executuve magistrate that provided that his "stile shall be "The President of the United States of America"; and his tille shall be "His Excellency." 2 THE ReCORDS OF THE FEDERAL CONVENTION OF 1787. al 185 (Max Famand ed.. 1911) [hereinafter FEDERAL CONVENTION]. Real title-conferring clauses did not use the empowening verb "vest." 135. See infra text accompanying note 171. J.).

136. See. e.g.. For Siewan Sch. v. Federal Labor Relations Auth.. 495 U.S. 641, 646 (1990) (Scalia.

137. Calabresi \& Rhodes, supra note 6, at 1195 (emphasis added). 
executive power of the President and the executive powers of various state officials. In particular, Section 2 of Article II imposes six key restraints on the executive power granted to the President by the Article II Vesting Clause. As was said in The Structural Constitution:

The text of Article II, Section 2 first explains that the President's power to be Commander in Chief extends to "the Militia of the several States," but only "when [they are] called into actual Service of the United States." It then explains that the President's power to require "Opinion[s], in writing" extends only to "the principal Officer in each of the executive Departments" and may concern only "Subject[s] relating to the Duties of their respective Offices." Third, it explains that the President's pardon power reaches only "Offenses against the United States" and does not reach "Cases of Impeachment." Fourth, the President's power "to make Treaties" depends on the "Advice and Consent of the Senate" and requires that "two thirds of the Senators present concur." Fifth, the President's appointment power is subject to senatorial "Advice and Consent," and "Congress may by Law vest the Appointment of ... inferior Officers ... in the Courts of Law, or in the Heads of Departments." Finally, the President's power to make appointments during congressional recess is limited to "granting Commissions which shall expire at the End of [the Senate's] next Session."138

These six provisions of Article II, Section 2 all help to limit and give content to the otherwise potentially vast grant of power that the Vesting Clause of Article II confers on the President. Thus, Article II, Section 2, when read in conjunction with Article I, Section 8, makes clear that the President will not have many of the arguably "executive" powers of King George III. ${ }^{139}$ Section 2 thus ensures that the President was not to be an elective "Monarch" (like the then King of Poland) as Thomas Jefferson, for one, feared. ${ }^{140}$ The President was not to have an unchecked treaty-making or appointment power, an unlimited pardon power, or the authority to serve as Commander in Chief of the state militias even when they had not been federalized. We know that the President does not have any of these regal powers because of the restraints that Sections 2 and 3 of Article II impose. Hence, construing the Executive Power Clause as a power grant hardly renders the rest of that Article superfluous. ${ }^{141}$

138. Id. at $1196 \mathrm{n} .216$ (alterations in original) (citations omitted).

139. See Monaghan, supra note 6 , at 13 (describing executive powers of monarchs as including right unilaterally to make treaties, war and peace, and offices); see also FORREST MCDONALD. THE AMERICAN PRESIDENCY: AN INTELLECTUAL HISTORY 17 (1994) [hereinafter MCDONALD, AMERICAN PRESIDENCY] (noting that Congress possesses many powers traditionally considered executive).

140. Letter from Thomas Jefferson to John Adams (Nov. 13, 1787), in THE PolitiCAL Writings of Thomas JefFerson 81 (Merrill D. Peterson ed., 1993) [hereinafter JefFERSON].

141. The executive power grant is also limited by the exemplary nature of the Article 11, Scction 2 list. While that list does not purport to define executive powers exclusively, it does serve as an example of the kinds of power that it was thought the Executive would have. Perhaps something of relevance might 
Rather, Sections 2 and 3 of Article II become all the more vital to limit and define the otherwise immense power that Section 1 of Article II grants. ${ }^{142}$

\section{The Minimalist Plain Meaning of Executive Power}

Throughout this Section, we have argued for the proposition that the Executive Power Clause is an actual grant of power to the President, and that it does not merely tell the People that under the Constitution there will be only one Chief Executive Officer with the title of "President" who will exercise the enumerated powers granted in the rest of Article II. Before turning to the remaining textual provisions that bear on the unitary Executive debate, we think it is incumbent upon us to provide a minimal definition.

Justice Scalia has rightly said that a thorough scholarly treatment of this subject could take thirty years to complete and fill 7000 pages. ${ }^{1+3}$ For now, therefore, we wish only to advance an argument for the quite narrow claim that the vesting of "the executive Power" in the President grants him the power to "Execut[e]" the laws passed by Congress. ${ }^{144}$ In other words, the "Executive Power Clause" informs the people that the President is constitutionally empowered to carry federal law into effect.

To begin to understand why this is the case, consider that the verb "executive" comes from the verb "to execute," which means to perform, to put into action. ${ }^{145}$ One can thus execute a plan, an instruction, an intention, or

be drawn from the canon of construction ejusdem generis. which usually applics when general words follow an enumeration of persons or things. BLACK'S LAW DICTONARY 517 (6th ed. 1990). Here. of course, there is the difference that the general words precede the specific enumeration. instead of following it.

142. Lessig and Sunstein assert that our construction of the Executive Power Clause leads to the conclusion "that the judicial branch has a wide range of inherent and (legislatuvely) unregulable judicial authority beyond that enumerated and granted by Congress." Lessig \& Sunstein, supra note I. al 50. They claim that since we read the Executive Power Clause to be a power grant. we must also believe that the Constitution gives the federal courts a broadly unregulable inherent power to dectde certaın kinds of eases.

We disagree. Our theory does not inexorably lead to the conclusion that broad and unregulable "inherent" judicial powers must exist, such as. for example. an unregulable power to issue structural injunctions. We do believe that, whatever the content of the judical power. It must be vested in a Supreme Cour and any inferior federal cours created by Congress. But. as Professor Calabresi and Kevin Rhodes suggest in The Structural Constitution. Article III differs from Article II in that the former contasns very broad grants of power to Congress to regulate the jurisdiction of the federal courts. Calabresi \& Rhodes, supra note 6, at 1181-83, 1192-93. 1204-06. Congress' power to limit the junsdiction of the federal courts (coupled with the fact that the federal courts possess only limited grants of jurtsdiction in the first place) means that the text of Article III lets Congress regulate when the judicial power can be exeressed. No comparable authority exists whereby Congress might regulate the circumstances in which the President may exercise his executive power.

Moreover, even if Article Ill did not grant Congress power over the junsdiction of the federal courts. it is still the case that the Article III. Section 2 jurisdictional grants are introduced by a phrase thal makes clear that the judicial power shall "extend to" only the nine categones of cases or controversies set forth in the Article.

143. Scalia, supra note 11. at 852 .

144. Even arguing for this narrow claim fully and adequately would take more tume and fill more pages than is permissible here. Nonetheless, we feel obliged to stan the task. even if ue cannot complete it in this Article.

145. See 1 JOHNSON's DICTIONARY, supra note 116, at 683; see also S OXFORD ENGLISH DICTIONARY 
a law. When we examine the plain dictionary meaning of "executive," we note that it means "active; not deliberative; not legislative; having the power to put in act the laws." branch of the government which is concerned or charged with carrying out the laws, decrees, and judicial sentences." 147 Therefore, we think it is clear that the Executive Power Clause vests the President with at least the power to put federal law into effect.

Section 1 might grant more than just that literal power. It might also grant all those rights and authorities that normally belong to the Executive, that is, "that branch of the government which is charged with the execution of the laws," 148 e.g., the powers of appointment and removal, the veto power, the power to control the armed forces, the foreign affairs power, etc. ${ }^{149}$ But for now, we need not take a position on this broader, historically based understanding of executive power. Presently, it is enough to declare that the Clause does what it says: It vests the power to execute the law with the President. ${ }^{150}$ We shall return to the broader conception in Section E of this Part.

It is time now to sum up the case that the Executive Power Clause of Article II, Section 1 is actually a power grant and not a naming and numbering provision. As we said above, the Vesting Clause of Article III must be a general grant of the judicial power (that is later qualified by Section 2 of Article III), or the federal courts lack a constitutional source of their power to act. And if the Judicial Power Clause is a power grant, the analogous

520 (2d ed. 1989) ("Execute" comes from Latin "ex(s)ecut," past participle stem of "ex(s)equi," mcaning

"to follow out.").

146. 1 JOHNSON'S DiCTIONARY, supra note 116 , at 684 .

147. 5 OXFORD ENGLISH DICTIONARY, supra note 145, at 522.

148. Id.

149. Lessig and Sunstein claim that to unitary executivists, the "'Executive power' means . . a all power not legislative and not judicial." Lessig \& Sunstein, supra note 1, at 12. That understanding of executive power is not the one we embrace, nor do we know anyone other than Lessig and Sunstein who has such an understanding. There are many powers that are neither legislative nor judicial that we do not believe belong to the President, to wit the power to enact ex post facto laws. Clearly Congress may not pass such laws, see U.S. CONST. art. I, $\$ 9, \mathrm{cl} .3$, nor may judges make such laws, for they lack the authority to legislate. No one believes that the fact that neither Congress nor the judiciary can pass ex post facto laws indicates that the President may. Thankfully, there are some powers not granted by "We the People" to any branch of the federal government.

150. Lest the reader be confused, we have not abandoned the notion that no branch of the federal government can lay claim to "inherent powers." Our reading of the Clause is not based on any notion of authority or power that is "inherently" executive. Instead, we are saying it actually grants a certain authority: the power to execute the law. This contention is no more based on claims of inherent authority than is the assertion that the House can establish its own internal rules. See U.S. CONST. art. I, $\$ 2$, cl. 5. Neither claim is based on some ill-defined, amorphous notion about the nature of congressional or executive authority. Rather, both are solidly grounded in constitutional text. One may legitimately disagree with the interpretations, but one cannot fairly assert that either is an example of a claim of inherent authority. Our later claim that removal authority is part of the executive power, see infra part III.F, is entirely consistent with our aversion to inherent powers as well. When we assert that executive power includes the authority to remove executive officers, we are making a claim based on the text and thus not resorting to arguments of inherency. 
Executive Power Clause must be a power grant as well..$^{\mid 51}$ The plain dictionary meaning of the Executive Power Clause suggests that the power the Clause grants the President includes at least the power to execute all federal laws. ${ }^{152}$

B. The President's Constitutional Grant of the Executive Power Is Exclusive: It Is Not Concurrently Shared with the Congress

The Executive Power Clause grants "the executive Power" solely and exclusively to the President; it gives Congress no power whatsoever to create subordinate entities that may exercise "the executive Power" until and unless the President delegates that power in some fashion. The Clause thus should not be read the way most opponents of the unitary Executive would read it:

Section 1. The executive Power of the United States shall be vested in one President, and in such inferior entities as the Congress may from time to time ordain and establish.

Thus, the constitutional text suggests that administrative entities inferior to the President must get their executive power to act by presidential delegation, whereas inferior entities subordinate to the Supreme Court (although they are created by Congress, as are Cabinet departments) get their judicial power to act directly from the Constitution itself. From this, we deduce that Congress has the power to create inferior entities that will be constitutionally empowered to exercise the judicial power without the assent of the Supreme Court, but it may not create inferior entities that will be constitutionally empowered to exercise the executive power without the acquiesence of the President. ${ }^{153}$ Once created, these agencies and officers executing federal law must retain the President's approval and be subject to presidential superintendence if they are to continue to exercise "the executive Power." Accordingly, we think that antiunitarians are wrong to assert that the Executive Power Clause does not preclude Congress from interfering with the President's power to control the administration. By granting "the executive Power" exclusively ${ }^{\text {ist }}$ to the

15I. The use of the mandatory word "shall" in the Executive Power Clause supports our thesis because Congress has no power grant that trumps the Executive Power Clause's empowerment of the Presidenl; neither congressional nor judicial action can deprive the President of his power to execute the laws nor is such action necessary for him to be able to execute the laws. See Calabresi \& Rhodes. supra note 6, at $1175-79,1181-84$.

152. We thus disagree with Professor Strauss' interpretation of the meaning of execuluve power. Strauss believes that the grant of executive power clearly has resonance in foreign affars but has less clear meaning in domestic affairs. See Strauss, supra note 3, at 598. We think Professor Strauss has it backwards. The executive power, though it encompasses some foreign affairs or military authority. is quintessentially about executing the law, a function most would describe as domestic.

153. See also Lawson, supra note 67, at 1242-44 \& n.72

154. The exclusivity of the power grant to the President is emphasized by the fact that the Juducial Power Clause grants power concurrently to both the Supreme Court and inferior federal courts. 
President, the Clause forecloses Congress from creating "independent" executive entities.

If the Executive Power Clause did not exist as an exclusive power grant, and if there were no other provisions (like the Take Care Clause) that confirmed the grant to the President of "the executive Power," then perhaps Congress could create executive entities by statute as the Continental Congress did under the Articles of Confederation. ${ }^{155}$ Independent agencies and counsels might then be defended as being both necessary and proper means for Congress to use "for carrying into Execution" its other enumerated powers, such as the commerce power. The Necessary and Proper Clause might then serve as the constitutional fount of all federal executive power and authority to act.

But the Executive Power Clause does exist, and it does constitute an exclusive grant of "the executive Power" to the President. It can no more be overridden or supplemented by Congress than can the First Amendment. The exclusivity of the power granted by the Executive Power Clause confirms our view that Congress cannot create independent entities under the Constitution as it could under the Articles of Confederation. Only one officer in the U.S. government (and his delegees) may exercise "the executive Power."156

\section{The Take Care and the Opinions Clauses}

Contrary to what Lessig and Sunstein appear to believe, the Take Care Clause and the Opinions in Writing Clause actually bolster our case. Both Clauses contemplate a role for the President, and for no one else, in the administration of the government. This "no one else" most emphatically includes the Congress, whose members are actually precluded elsewhere in the text of the Constitution from being able to serve as "[o]fficers of the United States." ${ }^{157}$ It is hard to imagine that a document that forbids members of Congress from serving as executive officers would nonetheless allow such members to control indirectly the administration of the laws that they were

155. See infra part IV.

156. Professor Calabresi believes that an analogy may be helpful here. Congress has the exclusive power "[t]o declare War," but only a concurrent power to "regulate Commerce . . . among the several states." U.S. CONST. art. I, $\S 8$, cls. II, 3. This means of course that the several states cannot declare war when Congress fails to do so, but they may regulate interstate commerce (for the most part) when Congress prefers to remain silent. Since the Executive Power Clause confers an exclusive power on the President, just as the War Power Clause confers an exclusive power on the federal government, Congress cannot fill any presidential silences by acting to create independent executive structures that will in essence excrcise the executive power. The President does not share his executive power with anyone, although he may delegate it, just as Congress does not share its war power with anyone, although it may enlist others in various military tasks.

157. U.S. CONST. art. I, $\S 6, \mathrm{cl} .2$ ("[N]o Person holding any Office under the United States, shall be a Member of either House during his Continuance in Office."). For a detailed historical and normative discussion of the Clause, see Steven G. Calabresi \& Joan L. Larsen, One Person, One Office: Separation of Powers or Separation of Personnel?, 79 CORNELL L. REv. 1045 (1994). 
disabled from controlling more directly. ${ }^{158}$ Such indirect political control will necessarily exist with any so-called "independent" agency or officer because absent presidential control, congressional oversight and appropriations powers become the only concern for the officers of the allegedly "independent" agencies. There is no such thing in Washington as a politically "independent" agency. ${ }^{159}$

The very language of the Take Care Clause confirms that the President possesses unique powers with respect to the execution of the law. Thus the Clause is phrased somewhat peculiarly, as if it imposed a duty on the President rather than granting a power. As Professor Calabresi and Kevin Rhodes said in The Structural Constitution, if the Take Care Clause were

a grant of power, one would expect it to read: "[The President] shall have power to ensure that the laws be faithfully executed." Instead, the Clause reads: "[The President] shall take care that the Laws be faithfully executed." The italicized language suggests an obligation of watchfulness, not a grant of power. This obligation could not be fulfilled unless the Article II Vesting Clause was, in fact, already a substantive grant of executive power to the President. Accordingly,. the use of the verb "take care" in the Take Care Clause bolsters the power-grant reading of the Vesting Clause of Article II. ${ }^{160}$

The point here is that the duty-imposing language of the Take Care Clause makes sense if the President has already been given a grant of the executive power by the Executive Power Clause. Otherwise, how could the President possibly live up to the duty that the Take Care Clause imposes? The Take Care Clause perhaps limits and defines the Executive Power Clause's grant of executive power by making it clear that the President has no royal prerogative

158. Congress, of course, can legitimately control the administration of federal law, to some degree. by statutorily placing certain functions in some executive departments and agencies. rather than in other executive departments and agencies. Moreover, whenever Congress passes a constututionally valid law the President is, of course, bound by the Take Care Clause faithfully to execute that law. The point here is that Congress, in controlling agencies, must act through laws. Unlike the President. Congress could not legally command that an agency do something or desist from taking an action without passing a law. See infra part III.E.

159. See Calabresi, Some Normative Arguments, supra note 9.

160. Calabresi \& Rhodes, supra note 6. at $1198 \mathrm{n} .221$ (citations omtted). Professor Calabresi is indebted to his colleague Gary Lawson for this construction of the Take Care Clause. 
to suspend statutes. ${ }^{161}$ It does not, however, eviscerate his powers of control and supervision over the administration of the federal law. ${ }^{162}$

Similarly, the Opinions Clause empowers the President to obtain information in writing on government matters precisely so he will be able to issue binding orders to his subordinates. ${ }^{163}$ We can see this if we contrast the Clause with the State of the Union Clause, another textual provision that is obviously concerned with exchanges of information. As was explained in The Structural Constitution:

The State of the Union Clause ... imposes an obligation on the President only "from time to time" and only on general matters such as the circumstances of the whole country. This Clause gives Congress no power to require presidential opinions in writing upon any subject relating to the President's duties, because the Clause governs information exchanges between two independent and co-equal departments of the national government. In contrast, the Opinions in Writing Clause enables the President to get information whenever he wants it, in writing, on any subject relating to official duties; this Clause does not seem to contemplate an information exchange "between independent and co-equal entities. ${ }^{164}$

Notions of hierarchy and of the unitary Executive are thus implicit in the Opinions Clause, as is illustrated by this comparison. Rather than sending the President reports of the officers' activities, the President obtains opinions and he makes the decisions. ${ }^{165}$

Lessig and Sunstein maintain that if the Executive Power Clause is a power grant, as we contend, then surely the Opinions Clause is redundant. But this overlooks the fact that the Opinions Clause might actually limit the

161. One can well imagine why the Framers might have wanted to forbid the President from exercising the ancient English royal power to suspend laws. Such a power is much more potent than cven an absolute veto over laws recently passed by Congress. An absolute veto, i.e., one incapable of being overridden, provides only the sitting President the opportunity to block legislation from becoming law. A suspending power, on the other hand, permits any President to nullify laws enacted during and prior to his taking office. The Clause's requirement to "faithfully" execute thus might preclude general suspending authority.

We note, however, the Take Care Clause's tension with the President's ability to pardon offenses. U.S. CoNST. art. II, \$ 2, cl. I. If the President pardons in an extremely broad and generous manner, say by pardoning all those who have been found to violate a particular environmental statute, that might seem to violate his Take Care responsibilities. We will discuss this tension at greater length in Part VI, when we recount President Washington's offer of a blanket pardon to rebellious Westemers. See infra part VI.A.2.

162. Originalist constitutional scholars, who have endorsed the concept of "departmental" threc-branch review for unconstitutionality, would deny that the President is (legally, as opposed to prudentially) bound to honor statutes that purport to take away any of his constitutional authorities or duties, particularly his authority to execute federal law (part of his executive power) or his responsibility to see that the laws are duly executed (derived from the Take Care Clause). Steven G. Calabresi, Thayer's Clear Mistake, 88 NW. U. L. REV. 269, 272-76 (1993); Frank H. Easterbrook, Presidential Review, 40 CASE W. RES. L. REV. 905 (1990); John Harrison, The Role of the Legislative and Executive Branches in Interpreting the Constitution, 73 CORNELL L. REv. 386 (1988).

163. Prakash, supra note 6, at 1004-07.

164. Calabresi \& Rhodes, supra note 6, at 1207 n.262.

165. Prakash, supra note 6, at 1007. 
President's general executive power to request opinions in writing. Note that the Clause only empowers the President to command that principal executive officers submit opinions "upon any Subject relating to the Duties of their respective Offices." Accordingly, the President may not command that an executive officer draft an opinion concerning the President's personal legal problems. Instead, the President can only command those officers to advise him on governmental matters. ${ }^{166}$

But what if we grant Lessig and Sunstein their assertion that our construction renders the Opinions in Writing Clause redundant, as Alexander Hamilton said that it was in The Federalist? ${ }^{167}$ So what? The Constitution is full of redundancies. Hamilton and Madison both said that the Necessary and Proper Clause was redundant. ${ }^{168}$ United States 1. Darby ${ }^{16 \%}$ said, in effect, that the Tenth Amendment was redundant, insofar as it expresses a truism. Incorporation of the Bill of Rights through the Due Process Clause of the Fourteenth Amendment could be said to make the Fifth Amendment Due Process Clause in some sense redundant. ${ }^{170}$ But no one is troubled by these redundancies because everyone understands why they are there. Redundancy, as noted earlier, is built in to reiterate an important point-to make sure that the point does not get lost. ${ }^{171}$ Certainly, redundancy does not exist to defeat the first iteration of the point that is being emphasized.

\section{The Militia Clauses and Execution}

Consider the Militia Clauses, hitherto ignored in the debate. Clause 15 of Article I, Section 8 says that Congress may call forth the state militias to "execute the Laws of the Union, suppress Insurrections and repel Invasions." 72 This Clause, read in conjunction with the Article II, Section 2 designation of the President as Commander in Chief of any "federalized" state militias, plainly contemplates presidential supervision of law execution during times of crisis. But that, in turn, makes it even clearer that the President is in charge of law execution during times of peace as well. If the President can "execute the Laws of the Union" through the barrel of a gun, is it really plausible to conclude that he lacked the constitutional authority to tell Treasury Secretary Hamilton what to do?

Or suppose that Congress decides to give the President the statutory power to call out the state militias whenever he thinks that law execution will benefit,

166. See infra part V.C for further discussion.

167. THE FEDERALIST No. 74, al 447 (Alexander Hamilion) (Clinton Rossiter ed., 1961).

168. THE FEDERALIST No. 33. at 202 (Alexander Hamilton) (Clinton Rossiter ed.. 1961): THE Federalist No. 44, at 284 (James Madison) (Clinton Rossiter ed. 1961).

169. 312 U.S. 100, 124 (1941).

170. See Adamson v. California, 332 U.S. 46, 66 (1947) (Frankfurter. J., concumng).

171. See supra text accompanying notes $135-36$.

172. U.S. CONST. art. $1, \S 8, \mathrm{cl} .15$. 
or whenever he thinks an insurrection or invasion is imminent. ${ }^{173}$ Can the President thwart the administrative/executive distinction that Lessig and Sunstein find in the Constitution merely by calling forth the militias on a permanent basis? He could then control the execution of Treasury statutes, claiming that those laws are not being adequately enforced. We think these examples and others show the implausibility of reading in an executive/administrative distinction where none exists. Like the Take Care and Opinions Clauses, the Militia Clauses bolster unitary executivism by showing that the President must control the execution of federal law in times of peace, as well as during periods of crisis.

\section{E. The Relevance of the Necessary and Proper Clause}

The Necessary and Proper Clause does not confer any powers upon Congress that call into question our textual analysis. The Clause gives Congress the power only "To make all Laws which shall be necessary and proper for carrying into Execution the foregoing Powers, and all other Powers vested by this Constitution in the Government of the United States, or in any Department or Officer thereof." 174 Lessig and Sunstein nonetheless claim that the Clause grants Congress the power "to determine the means for specifying how powers-and again, all powers-in the federal government are to be exercised." ${ }^{175}$ With respect to administration, "Congress . . . is vested with the power to determine how to structure the administration and how it is to function," ${ }^{176}$ and, more important, who will superintend the administration of particular laws.

Yet Lessig and Sunstein do not deny that the President must be able to control the execution of some laws. They acknowledge that the President must be able to direct execution of "executive" laws; that is, those laws passed pursuant to the Necessary and Proper Clause that are enacted to carry into execution the President's specifically enumerated Article II, Section 2 powers (e.g., to control the military and foreign affairs). ${ }^{177}$ But with respect to those laws that help carry into execution Congress' powers enumerated in Article I and elsewhere (so-called "administrative" laws such as those that establish departments for the collection and disbursement of revenues), they argue that less presidential direction is constitutionally necessary. ${ }^{178}$ Such laws help

173. Note that Congress cannot itself call forth the militias but may only "provide for calling forth the Militia." Id. Someone else (i.e., the President) must call forth the militia.

174. Id. art. I, \& 8, cl. 18 (emphasis added).

175. Lessig \& Sunstein, supra note 1, at 67 (emphasis added) (footnote omitted).

176. Id. at 68 .

177. Id. at 46 . Officers and departments created to help carry into execution Article 11 powers must be subject to presidential superintendence because, after all, these institutions exist to help effectuatc the President's Article II powers.

178. Id. 
carry into effect congressional powers, not presidential ones. Hence, Lessig and Sunstein say the President has no constitutionally fixed role in carrying such laws into execution. We disagree for a host of reasons.

\section{The Relevance of the Word "Proper"}

To begin with, a recent major article by Gary Lawson and Patricia Granger ${ }^{179}$ makes clear that the use of the words "proper" and "for carrying into Execution" was deliberate and that these words have real substantive bite. Put simply, they prevent Congress from using the Necessary and Proper Clause as a textual basis for a congressional power to alter the basic tripartite structure of our government, the federal structure of the Union, or the individual-rights guarantees of the original (Article I, Sections 9 and 10) Bill of Rights. ${ }^{180}$

We will not rehearse Lawson and Granger's detailed arguments here, but a few basic points are almost self-evident. Congress may only pass laws under the Sweeping Clause that are "proper" as well as necessary. As Lawson and Granger admirably demonstrate, the word "proper" is used in the Clause in an almost jurisdictional sense, precluding Congress from passing laws that would violate the constitutional structure established in the text of the Constitution itself. Thus, the Sweeping Clause may be used by Congress "to carry[] into execution" one of the enumerated powers that the Congress is granted elsewhere in the document or "to carryl] into execution" the power of another department of the government, such as the executive power or the judicial power. But the Clause may not be used improperly by Congress to alter the basic tripartite structure of the Constitution by, for example, creating independent agencies or legislative courts. ${ }^{181}$

179. Lawson \& Granger, supra note 90.

180. Id. at 333-34 (discussing theory's implications for separation of powers)

181. Lessig and Sunstein recognize that "propriely" serves as a constraint on congressional power. See Lessig \& Sunstein, supra note 1 , at $67 \mathrm{n} .278$. Their discussion of propnety does not. however. come to grips with the possibility that their version of the Clause might improperly let Congress take away the President's powers.

First, they invoke the Clause for the proposition that Congress determines who executes certan administrative laws. Such a use, we are told, is proper because the Clause itself tells us "[i]n as clear a textual commitment as possible ... [that] Congress . . . is granted the power to determine the means for specifying how powers . . . are to be exercised." Id. at 67. Thus, their interpretation of congressional power is proper because the very clause that requires propriety lets Congress determine who will execute.

It would seem to follow that under their interpretation of the Clause. Congress can tell federal judges how to decide cases (that is, how to use their judicial power). It could even mandate the use of coin tosses. Lessig and Sunstein cannot claim that such a law is improper by noting that Congress lacks the authority to so instruct the Court because, they assert, the Necessary and Proper Clause granis Congress the authority to "determine the means for specifying how powers-and again, all powers" are to be employed. Id. 


\section{The Relevance of "Carrying into Execution"}

The Necessary and Proper Clause provides that it can only be used "for carrying into execution" those powers "vested by this Constitution." This makes clear that Congress cannot use the Clause to carry into execution any unenumerated powers of government. Only powers "vested by this Constitution" can be carried into execution. The "for carrying into execution" language, in particular, does not authorize alteration of the basic tripartite structure of the government through the creation of independent agencies. This is because that language has to be read holistically against the backdrop of a Constitution that: (1) creates only a trinity of governmental powers; (2) gives an exclusive grant of all of the executive power to the President alone; (3) requires all exercises of legislative power to be conducted through the onerous procedural hoops of bicameralism and presentment; and (4) commands that all judicial power be exercised only where a case or controversy exists. When one puts these requirements together, one must ask which of the three traditional powers of government administrative officers may exercise.

It is clear that no independent agency or officer could exercise an unenumerated power of government because no such unenumerated powers exist. It is just as apparent that such an agency or officer could not exercise executive power because the President (and his delegees) are the only officers vested with the executive power and authorized to exercise that power. Nor could such an agency or officer exercise judicial power, because the strictures of the case or controversy requirement would not be present. And, finally, it is obvious that such an agency or officer could not exercise legislative power because that can be done only if the requirements of bicameralism and presentment have been satisfied.

It follows, then, that Congress could not "carry[] into execution" any constitutional power by creating an independent officer or agency because such an officer or agency would be unable to exercise executive, legislative, or judicial power under the text of the Constitution, and there are no other powers of government available to be exercised. And it is not enough under our Constitution for an officer to be statutorily empowered to act; she must be constitutionally empowered to act as well. Put another way, Congress can no more use the Necessary and Proper Clause to override the constitutional trinity of powers and the vesting of all executive power with the President than it could use the Clause to override the First Amendment to "carry[] into execution" the Alien and Sedition Acts.

Finally, even if an administrative officer could somehow be said to be exercising executive (or legislative or judicial) power, one must ask if the power to establish independent administrative officers is granted elsewhere in the Constitution. As was said in Hail to the Chief Administrator, if Congress is to invoke the Necessary and Proper Clause as a basis for legislation, it must 
first identify an independent grant of power that it is attempting to "carry [ ] into execution." 182 The "for carrying into execution" language empowers Congress only to take subsidiary actions in aid of, or to further, the already enumerated powers that Congress itself or another department or officer possesses. A perusal of the Constitution quickly confirms that there is no congressional, executive, or judicial authority for making execution of federal law independent of the President. Hence, the Clause may not be employed to do so. ${ }^{183}$

\section{There Is No Special Relationship Between the Take Care and the Necessary and Proper Clauses}

Lessig and Sunstein attempt to establish a "special relationship" between the Take Care and Necessary and Proper Clauses by pointing out that a variation of the word "execute" is found in both of them. ${ }^{134}$ Because the Necessary and Proper Clause grants Congress the power to make laws "for carrying into execution" its own powers, perhaps Congress has authority to determine who will execute congressional laws. Does not the Clause straightforwardly permit Congress to determine who ought to "carry[] into execution" its statutes? And does not the Take Care Clause compel the President faithfully to respect such decisions?

Such an argument, however, overlooks the different ways in which derivations of the word "execute" are used in the Take Care Clause and the Necessary and Proper Clause. We know the President has both the duty to take care that the laws be faithfully executed and "the executive Power," i.c., the constitutional power to enforce, administer, and implement federal laws. On the other hand, the Necessary and Proper Clause does not grant Congress "the executive Power" nor does it ask that Congress "take care that the laws be faithfully executed." The Clause does not grant Congress the power to determine who will "carry[] into execution" its laws. Instead, it gives Congress the power to implement its Article I powers, and other federal governmental powers, by passing laws in aid of implementation. Thus, while the President's Executive Power Clause and Take Care Clause are quintessentially about law execution, Congress' Necessary and Proper Clause is quintessentially about ensuring the means of implementing other enumerated powers.

If one thought that the mere presence of the same root word in both Clauses created a special congressional claim to determine who would execute federal law, one would also have to believe that the Necessary and Proper Clause created a nexus with the Militia and the Presidential Oaths Clauses.

182. See generally Prakash, supra note 6, at 1010-11.

183. Id. at 1011 .

184. Lessig \& Sunstein, supra note 1, at 69. 
After all, the Militia Clause contains the word "execute,"18s and the President, before beginning the "Execution of his Office," must take an oath affirming that he "will faithfully execute the Office of President of the United States."186 May Congress determine who takes the Presidential Oath or who may execute the Office of the President? Surely not. The Constitution establishes procedures for determining who may take the Presidential Oath and execute the Office of the President. Why would we then interpret the Clause to let Congress choose who can execute federal law? The Constitution already establishes who is responsible for execution of federal law.

If the Article II Executive Power Clause did not exist as an exclusive power grant, and if there was no other provision (like the Take Care, Opinions, and Militia Clauses) that confirmed that grant to the President of the authority to superintend the administration of federal law, then perhaps Congress could create executive entities by statute. Independent agencies might then be defended as being both the necessary and proper means for Congress to ensure that the laws it enacted would be executed. But the Article II Executive Power Clause does exist, and it does constitute an exclusive grant of "the executive Power" to the President. It can no more be trumped by Congress under the Necessary and Proper Clause than under any other provision of the Constitution. $^{187}$

\section{The Real Purpose of the Clause}

Thus far, we have focused on what the Necessary and Proper Clause does not permit Congress to do. We turn now to a consideration of what the Clause was actually meant to accomplish. Textually, the Clause is only about means, not ends. ${ }^{188}$ It takes the powers of the federal government as given ("vested by this Constitution") and permits Congress to help all three of the branches in implementing their respective constitutionally enumerated powers. As Lawson and Granger observe, "[t]he enumerations of power in the other seventeen clauses of Article I, Section 8 and elsewhere in the Constitution essentially provide the subject matter for the exercise of [the Necessary and

185. U.S. CoNST. art. I, $\$ 8$, cl. 15 .

186. Id. art. II, $\S \mathrm{I}, \mathrm{cl} .8$.

187. We think it unlikely that a sensible drafter would mention a fundamental power of Congress in so obscure a way in a document that carefully enumerates and cabins all govemmental powers. A holistic and contextual examination of the text reveals other more plausible ways to read the "for carrying into execution" language and makes clear that Lessig and Sunstein read too much into it.

188. In claiming the Clause has nothing to do with ends, we only mean that the Clause does not permit Congress to determine who will exercise federal governmental powers. As noted above, the Constitution already establishes who will exercise federal governmental powers. 
Proper Clause]." 189 When the Clause authorizes the means, it quite obviously helps "carry[] into Execution" a power of the federal government. 190

The Necessary and Proper Clause, then, is centrally concerned with means and takes the Constitution's vesting of powers as a given. What kinds of laws does it authorize that might be of aid to each of the three branches? With respect to Congress, the Clause might provide a basis for laws that allow the Senate and the House to use effectively their enumerated powers, such as the power to legislate generally, the impeachment power, and the power to establish internal congressional rules. Thus the Clause allows Congress to provide funding in aid of carrying out these powers and to create congressional institutions that would help assist in the exercise of these powers. With respect to the courts, the Clause allows Congress to help the federal judiciary carry into execution the judicial power by providing for law clerks and secretarial support. And, with respect to the executive branch, the Clause would allow Congress to institute an agency to help the President wisely employ his pardoning power, or to establish a department to assist the President in selecting officers for nomination. Most important, the Clause allows Congress to establish officers to assist the President in exercising his "executive Power."

We thus agree with Lessig and Sunstein insofar as they acknowledge that the Clause enables Congress to provide the means of implementing the powers of the three branches. But when they insist that Congress can determine how all federal powers will be implemented, they are on shaky ground. ${ }^{191}$ Congress does have the power to help carry into execution all of the federal government's powers including those of the other branches. But, it does not have the power to enact laws telling the other branches "how they ought to carry into execution" one of their powers. Thus, for example, Congress could not require that the President consult with the leadership of Congress before he vetoes a bill. ${ }^{192}$ The President may veto bills at his nondelegable and unreviewable discretion.

Simply put, the Clause has nothing to do with altering constitutionally granted powers and prerogatives; nor does it allow Congress to tell constitutionally empowered actors how they can implement their exclusive powers. The Clause has everything to do, however, with permitting Congress

189. Lawson \& Granger, supra note 90 , at 324.

190. Hence, there is a connection between the Take Care and the Necessary and Proper Clauses. See Prakash, supra note 6, at 1010-11. But the relationship between the two is the same as between the Necessary and Proper Clause and any power of the federal govemment.

191. Lessig and Sunstein insist that "[t]he choice over who gets to specify the how of federal execution was made by the framers when they drafted the Necessary and Proper Clause." Lessig \& Sunstein. supra note 1, at 69 (emphasis added). While it is true that Congress may assist the other branches and itself in the "how" of carrying their respective powers into effect, the choice of who may specify who gets to execute the law is not part of the power conferred to Congress by the Necessary and Proper Clause. The choice of who will execute is decided elsewhere in the Constitution: The Exccutive will execute all federal law.

192. U.S. CONST. ant. 1, § 7, cl. 2. 
to help itself, the President, and the federal judiciary exercise their own respective powers. ${ }^{193}$

\section{Creating Offices and Cabinet Departments}

Although the Necessary and Proper Clause does not permit Congress to tell the President how he ought to implement his own constitutional powers, it does enable Congress to structure the administration of federal law. Thus, Lawson and Granger are right to note that "virtually all federal laws" are enacted pursuant to the Clause. ${ }^{194}$ Most congressional powers really only allow Congress to legislate in a minimal sense: that is, to state what is illegal. ${ }^{195}$ The Necessary and Proper Clause, however, allows Congress to legislate beyond this bare minimum, permitting Congress to provide the means by which it and the other branches can implement their constitutionally vested powers.

Thus, the Necessary and Proper Clause provides the constitutional source of Congress' power to create "executive offices." To help effectuate the President's "executive Power," Congress may create officers and departments whose job it is to assist the President in administering federal law. Unlike the specific congressional power to establish inferior tribunals, which is mentioned twice in the Constitution, ${ }^{196}$ no source of authority other than the Necessary and Proper Clause exists that would permit Congress to establish inferior executive officers and offices. The power conferred by the Clause is vital indeed.

Now, when Congress provides the President with "assistants and officers" and with Cabinet departments, it has broad latitude to tell these mere creatures of statutory law how, and on what matters, they will be available to help the President in executing federal law. This is so because the Necessary and Proper Clause does empower Congress to create the entire superstructure of law execution. The President is the Chief Executive, but without the congressional enactment of laws creating departments and officers, he would be the only executive. ${ }^{197}$ Statutory officers can be limited to carrying out certain statutorily specified tasks.

It is thus of course permissible for Congress to decide to have separate Departments of State and Defense or to have one department covering both subjects. Congress can set terms of office that last indefinitely (subject to

193. Prakash, supra note 6 , at 1010.

194. Lawson \& Granger, supra note 90, at 324.

195. Id.

196. U.S. CONST. art. I, § 8, cl. 9; id. art. III, § I.

197. Of course, the Vice President might be considered another executive officer. Yet his functions are, ordinarily, largely legislative, namely sitting as President of the Senate and breaking ties in Senate votes. Id. art. I, $\$ 3, \mathrm{cl} .4$. The Constitution contemplates that he will become an executive only upon the President's resignation, death, or inability to discharge the powers or duties of office. Id. art. II, $\S 1, \mathrm{cl} .6$. 
presidential removal ${ }^{198}$ and congressional impeachment, of course), or it can grant officers limited one-year terms, thus requiring yearly congressional review of an officer's performance if that officer is to continue in office. Congress may structure the administration of the government in a whole host of other ways as well. But it must do so in a manner that comports with the President's exclusive power to control all instances where the power to execute the laws is exercised. The Constitution requires no less. We turn in the next Section to a discussion of three minimal, constitutionally necessary mechanisms of presidential control. No organizational structure constructed by Congress can interfere with any of these control mechanisms without violating the Constitution.

\section{F. The President's Power To Execute the Laws: Three Constitutionally Necessary Mechanisms To Control Inferior Execurive Officers}

As discussed above, the Executive Power Clause grants "the executive Power" solely and exclusively to the President. Congress may not exercise "the executive Power" itself, nor may it give that power to other subordinate entities. Until and unless the President delegates "the executive Power" to those entities or officers, they are constitutionally disempowered from acting. ${ }^{199}$ The Necessary and Proper Clause does not change this analysis because it does not grant Congress the power to strip the President of his constitutional authority and obligation to supervise and control the executive branch. Thus, the text of the Constitution confers on the President the exclusive power to superintend the execution of all federal laws, and Congress can neither add to nor diminish the scope of this power.

We saw in the previous Section that the Necessary and Proper Clause permits Congress to assist the other branches in the exercise of their powers. We saw as well that Congress frequently assists the President in the exercise of his "executive Power" by creating inferior executive officers and departments because, without them, the vast majority of federal laws would go unexecuted and the President would be without advice and help as he sought to carry out his constitutional powers and duties. Although the President has the exclusive power to execute federal law, he cannot even begin to fulfill that task acting alone. Happily, the Constitution does not contemplate that the President single-handedly will deliver all the mail, collect the tariffs on all imported goods, or coin personally all the money that is to be coined. Instead, the Constitution mentions (and thus contemplates) that there will be other

198. See infra part III.F.

199. Again, the Executive Power Clause of Article II does not provide:

Section 1. The executive Power of the United Stales shall be vested in one President, and in such inferior entities as the Congress may from time to tume ordain and establish.

Cf. U.S. CONST. art. III. 
"executive" officers. We consider here the relationship between these executive officers, statutorily charged with assisting in law execution, and the President, who is constitutionally charged with the power and responsibility of law execution.

Terms similar to "executive officer" appear in various places in the text of the Constitution. ${ }^{200}$ The terms imply a subordinate/superior relationship with the President-the Constitution's Chief Executive Officer-by use of the word "executive," by their position in Article II, or by similarities to terms used in Article II. Such officers are clearly of the executive variety and thus presumably subservient to the officer who already possesses the executive power. They can be used to execute federal law or to help the Executive carry out his other powers and responsibilities, such as the appointment and veto powers. ${ }^{201}$ We might also pause for a moment and remark upon what the Constitution does not say about these "executive officers." Though the Constitution refers to duties ${ }^{202}$ and powers ${ }^{203}$ of officers, it nowhere grants any executive officer other than the President any duty or power. ${ }^{204}$ Nor does

200. See, e.g., id. art. II, § 2, cl. 1 ("principal Officer"); id. art. Il, \$ 2, cl. 2 \& \$\$ 3-4 ("Officer[] of the United States"); id. art. VI, cl. 3 ("executive ... Officers"); id. amend. XIV, \& 3 ("officer of the United States"); id. amend. XXV, \& 4, cl. 2 ("principal officers of the executive department").

201. We note that although the Constitution refers to the President as "Commander in Chief," id. art. II, $\$ 2$, cl. I, it does not refer to him as "Chief Executive." The absence of such a provision is littlo cause for alarm. The grant of the executive power to the President, and only the President, establishes him as the Chief Executive. All other executives exist merely to help him implement his authority.

202. Professor Froomkin has argued that the Inferior Officers Appointments Clause suggests that the department heads are somehow independent of the President because otherwise there would be no reason to give Congress the authority to vest the power to appoint inferior officers in the President or the department heads. See Froomkin, Agency Autonomy, supra note 5, at 799. Froomkin notes that the Constitution could have merely permitted Congress to vest authority in the President, who could then cither delegate that power to his subordinate department heads or accept their recommendations.

We think Froomkin has focused on one of the imperfections in the Constitution. See infra note 204 (discussing Strauss' claim about textual imperfections). Given the powerful textual support for the unitary Executive, we think it very unlikely that this rather minor Clause was meant to call into question what tho rest of the document makes clear. As we show, see infra notes 394-400 and accompanying text, the Clause's history supports our claim that the portion of the Clause permitting Congress to delegato appointment power to the President and department heads is but an imperfection.

203. U.S. CoNST. ant. I. \$ 8, cl. 18.

204. Professor Peter Strauss, the modern founding father of the field in which we are now writing, has called our attention to portions of the Constitution that seem to have contemplated that certain officers would have constitutionally established offices and dutics. See Strauss, supra note 3, at 601 n. 108; see also Letter from Professor Strauss to Steven G. Calabresi and Saikrishna B. Prakash (June 2, 1994) (on file with authors). Professor Strauss labels these instances as examples of the imperfections and oversights that are often found in enacted texts, id., and that is exactly how we view them.

Professor Strauss goes on, however, to claim that because the Constitution presumes that some departments were to have constitutionally established duties, we should view any statutorily established duties as the responsibility of the departments alone. Under this view, the President would only have the authority to oversee these departments, pursuant to the Take Care Clause.

While we are uneasy about our partial disagreement with Professor Strauss, we nonetheless think he puts too much emphasis on the mention of departmental duties and powers in the Constitution. These imperfections do not detract in any way from the notion that the President is the only officer of the federal government granted the constitutional power to execute federal law. Whatever the intent of the people who framed the Necessary and Proper Clause, with its oblique references to hypothetical departmental and official duties, the actual text of the Constitution simply does not contain any clauses that grant powers or establish duties for departments or their officers. As originalists, we feel bound to follow the constitutional 
it grant Congress the power to divest the President of any of his executive powers and redistribute them to other "executive officers."

Thus, all "executive power" found in the Constitution is only vested in one individual, the President. If anyone else is ever to exercise federal executive power, it must be as a result of the explicit or tacit delegation and approval of the President, ${ }^{205}$ because, as we noted earlier, no governmental actor can act in a manner that affects the rights of private parties unless that action is somehow ultimately authorized by the Constitution. The real question is not whether the President will control the executive officers, because they are, after all, helping him exercise his constitutional authority. Rather, the "important question is what form the President's power of control must take in order to assure a constitutionally unitary executive."206

Professor Calabresi and Kevin Rhodes have previously described three possible mechanisms by which the President could control inferior executive officers: removal, a power to act in their stead, and a power to nullify their acts when the President disapproves. ${ }^{207}$ We now are prepared to sketch out the beginnings ${ }^{208}$ of an argument as to why all three mechanisms of control must be clearly encompassed within the President's grant of the executive power. Let us consider first whether the President has a constitutional right to take action in the place of an inferior executive officer to whom a statute purports to give discretionary executive power.

Because the President alone has the constitutional power to execute federal law, it would seem to follow that, notwithstanding the text of any given statute, the President must be able to execute that statute, interpreting it and applying it in concrete circumstances. ${ }^{209}$ It is a grave mistake to conceptualize the President's ability to execute federal law as a power to act in an executive officer's stead. Under the Constitution, executive officers can act only in the President's stead, since it is the President and the President alone who can delegate to them the constitutional power that they must have if they are to execute laws. For example, if Congress establishes by statute a Treasury Secretary with the power and responsibility to expend appropriations and also provides a degree of discretion in an appropriations act, it is a mistake to view that statute as creating any duty or authority that belongs to the Secretary, even if the statute is written that way. Rather, it is the President,

text.

205. We think it obvious from the text of the Constitution that the President may delegate his authonty to execute federal law to executive officers. Of ail the Presideni's powers, this one necessinly requires the assistance of other officers and was traditionally delegable. Whether he may delegale any of his other powers (like the veto) poses questions beyond the scope of our inquiry.

206. Lawson, supra note 6, at 1243.

207. See Calabresi \& Rhodes, supra note 6. at 1166; see also Lowson. supra note 6, al 1243-45; Liberman, supra note 6. at 353-54.

208. We recognize that the argument we sketch out in thrs Section needs an enomous amount of additional elaboration and support.

209. More likely, the President may tell his exccutive officers how he would like a law to be executed. 
under our Constitution, who must always be the ultimate empowered and responsible actor. This is because the Constitution establishes that the President exclusively controls the power to execute all federal laws, and therefore it must be the case that all inferior executive officers act in his stead. A statute stating that the Secretary of the Treasury and other Treasury personnel will execute appropriation and tax laws only establishes that these particular officers will assist the President in carrying those laws into execution. ${ }^{210}$ Congress lacks constitutional power to do anything more.

If the President may make a decision that a statute purports to reserve for an inferior executive officer, by the same logic, the President must be able to nullify an action taken by an inferior executive officer. Once again, only the President has the constitutional power to execute federal law, and no governmental power may be exercised, including the law-execution power, without a basis in the Constitution for the exercise of the power. To give a nullification-power example, suppose the Secretary of the Treasury, in the exercise of her purportedly exclusive statutory discretion, decided to fine a bank for violation of certain banking laws. Because the Treasury Secretary would be ultimately exercising the President's "executive power," the President must be able, in effect, to reverse or nullify the Secretary's decision by withdrawing his delegation of the executive power, which the Constitution gives to him alone. ${ }^{211}$

Finally, consider whether the President's executive power allows him to remove inferior executive officers, either by firing them altogether, or by removing permanently their ability to exercise implicitly delegated executive power. On a cramped reading, the Constitution would seem to provide only one means of removing inferior executive officers: impeachment. ${ }^{212}$ While

210. We thus agree with Professor Gary Lawson when he says that the President may not empower another actor to direct the Secretary of the Treasury. See Lawson, supra note 6, at $1243 \mathrm{n.72}$. That is so because the President, subject to the three control minimums, takes the officers "as is." In other words, if the President wishes help in implementing appropriations, he may use only Treasury personnel, because those are the only people Congress, through the Necessary and Proper Clause, has statutorily authorized to assist him. We disagree, however, with the statement that "if a statute vests power to promulgate workplace standards in the Secretary of Labor, the President cannot personally promulgate safety standards." Id. Other members of the executive branch are there to assist the President in exccuting the laws; they may not take away his authority to do so.

211. Under certain circumstances, complications will arise. Where a statute requires the issuance of some regulations on a given date, and the President disagrees with the regulations as drafted by the Secretary but has no opportunity to revise them prior to the issuance date, it might be the case that the President is unable to revise the regulations. On the other hand, perhaps the President can order his Secretary to delay issuance, revise the regulations according to his desires, and then issue the regulations. If legal obstacles arise, the President might be able in theory to pardon the Secretary for failing to meet the statutory deadline, although in practice political realities will probably always make that an impossibility.

212. U.S. CONST. art. II, § 4; see Scalia, supra note 11, at 857-60 (discussing extent of executive power of removal in context of debate between originalists and non-originalists). Justice Scalia's discussion of the strengths and weaknesses of Chief Justice Taft's opinion in Myers v. United States, 272 U.S. 52 (1926) suggests that 30 years of research and 7000 pages of text would likely conclude that a historically well-grounded Hamiltonian reading of the relevant provisions of the constitutional text probably supports 
Congress has the sole power of impeachment, the President seems on a superficial reading of the Constitution to lack any textual grant of removal power once inferior executive officers have been appointed. Accordingly, it could be suggested that once appointed, all inferior executive officers should remain in office for life, unless they are impeached or there are statutory term limits that attach to the offices they hold.

Such an argument goes much too far, however, and overlooks the fact that although judges "shall hold their Offices during good Behaviour," 213 that is, until impeached, executive officers and judicial officers who are not judges (such as law clerks and other Article III support personnel) do not have such protection from removal. Thus, structural inference tells us that it must be the case that the members of each House of Congress must be able to remove their own officers, notwithstanding the lack of explicit removal authority, ${ }^{214}$ and without invoking the mechanisms of impeachment. Accordingly, when we turn to Article II, similar structural reasons and a host of historical and textual arguments persuade us that the President must also have a removal power so that he will be able to maintain control over the personnel of the executive branch. The President's power over nominations and his exclusively held executive power strongly suggest that he must be able to remove federal officers who he feels are not executing federal law in a manner consistent with his administrative agenda. Inferior executive officers are, after all, the President's men and women, assisting him in the exercise of his constitutional powers. If he decides that they are impeding his administrative program or are simply doing a poor job in providing what Hamilton might have called an "energetic" administration, he must be able to replace them with others. ${ }^{215}$

something like the following set of propositions: (1) The "executuve power" of English kings in the 18th century included an unlimited power to remove inferior executive officers, although it no longer included a power to remove judges or, certainly. Members of Parliament. The King retained this removal power. even though Parliament had the power to impeach. (2) Many, if not most, of the Kung's "execultve Powers" are explicitly given by our Constitution to Congress (as in Article I. Section 8, the power to make war or to create offices), or are shared between the President and the Senate (as happened with the appointment power and the treaty-making power). or, in many instances, are abolished outright (as with the power to confer titles of nobility). (3) Those few, limited executive powers that were not abolished or reapportioned in this fashion might be retained by the Executive and may be encompassed withun the phrase "the executive power" as it would have been understood in 1787. As Professor Monaghan's researeh shows. this does not include a power to act contra legem, since the Framers plainly believed the King lacked such power. (4) The removal power thus must be encompassed textually within the President's executive power as the Framers understood that term, and as Chief Justice Taft said in Myers, id. al 121-22.

213. U.S. CONST. art. III, $\S 1$.

214. Id. an. I. \$2. cl. $5 \& \$ 3 . \mathrm{cl} .5$.

215. It might be argued that since noninferior executive officers must receive Senate confirmation prior to taking office, Senate approval of decisions to remove them is required as well. THE FEDERALIST No. 77 , at 459 (Alexander Hamilton) (Clinton Rossiter ed.. 1961). The fact that the traditionally exceutive power of appointment was divided between the President and the Senate does not compel the conclusion that the traditionally executive power of removal was so divided as well. Consider Chief Justuce Taft's argument in Myers. 272 U.S. at 121-22 (maintaining that narrow limitation of Senate on presidentzal appointment power does not imply corresponding limit on removal power). 
Appointments to executive departments determine who will help the President implement his powers and responsibilities. It would make little sense to force the President to deal with officers who fundamentally disagree with his administrative or political philosophy. Suppose President Clinton could not have removed President Bush's Environmental Protection Agency Administrator, William Reilly. The Chief Magistrate might thus have found himself constantly overturning a subordinate magistrate's (Reilly's) construction and implementation of environmental statutes. Even worse, if Cabinet members served for life, unless impeached, President Clinton conceivably could have found himself with a Cabinet full of Republican appointees conspiring to thwart his Administration at every turn. In the scheme of the Constitution, which gives the President a clear and exclusive power to control all exercises of law execution, such an outcome seems implausible, since it would place enormous obstacles in the way of his ability to exercise "the executive power." If the President is to have effective control of his constitutionally granted powers, he must be able to remove those who he believes will not follow his administrative agenda and philosophy. ${ }^{216}$ We thus reject the idea that the President lacks a textually explicit power of removal, adopting instead the argument that the President may remove executive officers using his Vesting Clause grant of "executive Power" that allows him to superintend the execution of federal law. ${ }^{217}$

But even if one disagrees with the notion that the President can discharge an officer, the President may still revoke that officer's executive authority, leaving such an officer with a title and salary but with no authority to exercise executive power. Recall that if executive officers are to act, they must have a statutory and constitutional basis for their authority. That constitutional authority must come from the one individual constitutional actor invested with the executive power. Just as the President may withdraw his consent to the exercise of executive authority in particular instances, so may he completely withdraw his authority should he feel that an officer is no longer exercising

216. We thus disagree with the claim that a presidential removal power is "cither constitutionally superfluous or constitutionally inadequate." Lawson, supra note 6, at 1244. The removal power is not "something of relatively little constitutional significance." Without a removal power, the President could find himself spending all his time merely overturning the decisions of those who are supposed to be his subordinates or attempting to preempt these putative subordinates by reaching out and making final discretionary decisions before these officials have a chance to decide.

217. We disagree with Professor Lawson's assertion that since "even the strongest removal power does not ensure compliance with the Article II Vesting Clause, any such inference of a constitutionally based presidential removal power seems hard to justify." Id. at 1245 n.74. To us, this statement reflects too narrow a construction of the power that the Executive Power Clause grants the President. We agree with Professor Lawson that the Clause grants the President the power to control the execution of federal law. That removal authority, by itself, might not be an entirely satisfactory mechanism to achicve that control does not mean that it is not encompassed within the grant of "the executive Power." See supra notes 212 , 215. Rather, recognizing the limitations of the removal authority only bolsters the notion that there must be other means of control as well, such as the President's ability to make statutory decisions himself and the ability to countermand. Each of these mechanisms, taken in isolation, does not satisfy the Executive Power Clause. That surely does not mean that none of the mechanisms is derivable from this Clause. 
authority consistent with his views. ${ }^{218}$ Once his authority is withdrawn, the President must make all those decisions previously vested by statute in the now constitutionally disempowered officer, at least until the officer leaves office (and a new officer is appointed) or Congress, by statute, allows some other executive officer to act as the President's agent over those matters. The point is that even if the President cannot dismiss the officer, he can totally retract his executive power, thus rendering the officer a mere cipher in our constitutional scheme.

\section{G. Summary of the Textual Argument of Parts II and III}

We have now completed our originalist, textual case for the unitary Executive, and we summarize here the conclusions reached in Parts II and III. First, we have shown that the Constitution creates only a trinity of types of governmental powers, officers, and institutions. Second, we have argued that the Executive Power Clause is a grant of exclusive power to the President that allows him to control the execution of all federal laws. Third, this fact is confirmed by many other provisions of the constitutional text, including the Necessary and Proper Clause. Finally, the President must be able to control subordinate executive officers through the mechanisms of removal, nullification, and execution of the discretion "assigned" to them himself.

As we have said, we believe the textual case set out above is solid enough to stand on its own. Indeed, if one is convinced by our textual arguments, the historical case that follows is in a sense superfluous. Nevertheless, the historical discussion remains important for the light it sheds on the history behind the constitutional provisions that are the subject of this Article.

\section{Some Pre-Framing Historical Context: The Continental CONGRESS' EXECUTIVE POWER}

Taking Lessig and Sunstein's contextual admonition to heart, ${ }^{219}$ let us begin our historical inquiry by examining the period preceding the Constitution's drafting. As we noted above, when assembling the legislative history of a statute, one normally begins by analyzing the interval before the statute's enactment, rather than the period after. ${ }^{220}$ This principle has even more force where the statute amends, or supersedes, a prior statute. Contrasting

218. If one only believes in this minimalist view of the power to remove an executive officer, the question remains whether Congress can contınue to fund an officer of the United States whose sole function is to collect a salary. Though we are skeptical of the existence of such a congressional power. we take no position on the question.

219. We refer to their warning that we should construe ancient text in its histoncal context. See Lessig \& Sunstein, supra note 1, at 13.

220. See supra part I.C. 
the old and new statutes enables us to note differences in text and possibly to draw some conclusions. Similarly, in surveying constitutional legislative history, it behooves us to begin with the prior "Constitution" and garner some rudimentary understandings about its design. This quick synopsis of the structure of federal administration before and during the Articles-ofConfederation period will disclose that the rather dismal experience with congressionally controlled administration led to the establishment of a Chief Executive independent of the legislative branch.

As many have noted, the Continental Congress resembled a gathering of ambassadors from the thirteen sovereign states rather than a legislative assembly. ${ }^{221}$ Indeed, in the early years, Congress lacked a firm legal basis for its "legislation." With the adoption of the Articles in 1781 by the states, it acquired some legislative authority. Nonetheless, because states wished to preserve most of their respective powers and sovereignty, the Articles granted Congress very little authority. Congress had the war power, dealt with foreign affairs, directed the country's finances, and possessed other incidental powers. ${ }^{222}$ So far, these powers seem familiar. The Constitution grants many of them to the modern Congress.

Yet the Articles differed in at least one major and relevant respect from the Constitution: The Continental Congress also possessed the country's executive power. ${ }^{223}$ Congress could "appoint such other committees and civil officers as may be necessary for managing the general affairs of the United States under their [Congress'] direction."224 Though there was no formal grant of the executive power to Congress, the ability to direct the committees and officers who would administer federal law undeniably gave Congress such authority. ${ }^{225}$

221. Allan Nevins, The American States DURING AND AFTER tHe Revolution 1775-1789, at 660 (1924); Akhil Reed Amar, Of Sovereignty and Federalism, 96 YALE L.J. 1425, 1446-48 (1987).

222. ARTS. OF CONFED. art. IX, §§ 4-5.

223. To be sure, there was a "President" of the Continental Congress. Id. art. IX, § 5. Yct this President did not possess most of the constitutional powers that we associate with our President. See Jennings B. SANders, THE PResidency of the Continental Congress 1774-89: A Study in AMERICAN INSTITUTIONAL HISTORY 42 (1930). Sanders notes that the former President was "given no executive authority." Rather, he primarily "presided" over the sessions of the Continental Congress. HENRY BarRett learned, THE PREsident's CABINET 48 (1912).

224. ARTS. OF CONFED. art. IX, \$ 5 .

225. Many have acknowledged that the Articles created a congressional executive. For instance, the Virginia Plan, put forth before the Philadelphia Convention, proposed that a "National Executive" possess "the Executive rights vested in Congress by the Confederation." 1 FEDERAL CONVENTION, supra note 134, at 21. Edmund Randolph commented that under the Articles, "legislative and executive are concentrated in the same persons." 15 DOCUMENTARY HISTORY OF THE RATIFICATION OF THE CONSTITUTION 128 (John P. Kaminski et al. eds., [984) [hereinafter DOCUMENTARY HISTORY OF THE RATIFICATION]. Historian Jennings Sanders similarly noted that under the Articles, "[l]egislative and executive powers were assumed by Congress." Jennings B. SANDERS, Evolution of ExeCuTJVE DEPARTMENTS OF THE CONTINENTAL CONGRESS 1774-1789, at 3 (1935). Charles Thach likewise affirmed that the Continental Congress was "primarily itself the executive, the administrator." THACH, supra note 82, at 57. 
Since Congress possessed very little authority to regulate individuals, ${ }^{226}$ there was no need for the vast administrative bureaucracy all too familiar to us. Executive tasks primarily consisted of carrying out congressional instructions in the areas of war, foreign affairs, finance, and the post. To handle these duties, Congress in 1775 (even before the Articles' adoption) set up special administrative committees whose members directed execution under congressional commands. ${ }^{227}$ After experiencing difficulties with this administrative structure, Congress in 1776 moved to a system of standing committees, once again composed of Congressmen, who would take care that congressional dictates were heeded. ${ }^{228}$ Yet this system also proved deficient as members often were overburdened by their combined legislative and executive tasks. 229

By early 1781, Congress established executive departments headed by Secretaries. ${ }^{230}$ Congress appointed General Benjamin Lincoln as Secretary of War, with authority to inventory forces and provisions, transmit all orders of Congress to the military, commission officers, and inform Congress when more soldiers were necessary. ${ }^{231}$ Congress also appointed Robert Livingston as Secretary for Foreign Affairs. He was directed to correspond with foreign ministers and American ambassadors located overseas, to receive all applications of foreigners sent to Congress, and to provide information to Congress whenever Congress required. ${ }^{232}$ Robert Morris, selected for the new post of Superintendent of Finance, was both the chief disburser and collector of funds. He collected requisitions from states, ${ }^{233}$ provided funds to support federal officers, paid the interest owed on federal debt, and supplied the army and navy. ${ }^{234}$ Even after these officers were appointed, however, Congress continued to experiment with the administrative structure. ${ }^{235}$ The era before

226. See Saikrishna B. Prakash, Field Office Federalesm. 79 VA. L. REY. 1957, 1964 n.37 (1993).

227. See SANDERS, supra note 225, at 4; see also id. at 6 (desenbing special committee actuvities of Continental Congress). The Congress did, however. establish a separate Postmaster General with authonty to deliver letters and intelligence throughout the states. See 2 JOURNals OF CONTINESTAL CONGRESS 1774-1789, at 208-09 (Worthington Ford ed., 1905) (hereinafier JOURNaLS OF CONTINENTAL CONGRESS!: SANDERS, supra note 225 , at 153.

228. See SANDERS, supra note 225 , at 4 . Special committees contınued to play a role. Id. at 10 .

229. See id. at 4.

230. Some members "seeing the unwieldiness of so large a body and witnessing every day its inability to perform with efficiency and dispatch the executive functions, insisted that depantments be created of men not of Congress, to discharge such duties." Id. at 3. Others resisted these "monarehical tendencies." Id. at 4.

231. See 19 JOURNALS OF CONTINENTAL CONGRESS, supra note 227, at 236-37. LeARNED. supra note 223 , at 54 .

232. See 22 Journals OF CONTINENTAL CONGRESS, supro nole 227, al 87-92; see also SANDERs, supra note 225 , at 109,114 .

233. ARTS. OF CONFED. an. VIII. For a discussion of the Articles' requisituoning system, see Prakash. supra note 226 , at 1963-66.

234. See SANDERS, supra note 225, at 134. Congress also created a Comptroller, a Treasurer, and numerous other Treasury officials who. though they had statutory duties. Here statutonly subordinate to the Superintendent. Id. at 133.

235. Thach asserts that there was no possibility of preventing Congress "from conunuing to busy uself 
the Constitution's ratification was thus one of constant experimentation and flux in administrative structure.

Many grumbled that, notwithstanding congressional efforts to perfect administration, execution was still rather feeble. Alexander Hamilton, for one, characterized the administration as lacking "method and energy."236 Because the Articles lacked a proper Executive, Congress meddled too much with administrative details. ${ }^{237}$ "Congress is, properly, a deliberative corps, and it forgets itself when it attempts to play the executive." ${ }^{238}$ Thomas Jefferson thought executive and legislative powers ought to be kept distinct, as Congress had immersed itself in trifling executive details while neglecting more important legislative matters. ${ }^{239}$ Others thought that Secretaries were not sufficiently independent of Congress, requiring congressional sanction at every turn. $^{240}$

Some not only criticized congressional superintendence of administration, but actually proposed a familiar remedy: the creation of a single, independent Executive. For instance, as early as 1780, a group of New England delegates meeting in Boston urged that "national Concerns of the United States be under the Superintendency and Direction of one supreme Head."241 One commentator echoed Jefferson's observation that execution and legislation ought to be kept distinct, remarking that execution should be entrusted to one "great and fearful executive officer." ${ }^{42}$ Noah Webster argued that if the "power of the whole" was vested in a single person, "the execution of laws will be vigorous and decisive." 243 Others thought that George Washington "might wisely be made king."244

We glean three vital lessons from the period immediately preceding the Constitution's ratification. First, Congress effectively possessed the "executive

with details, to take up departmental matters that came before it from any source and to assign their consideration to special committees without consultation with the departmental head." THACH, supra note 82. at 70. According to Thach, members of Congress, until the end of the Articles period, acted as the real administrative heads of the various departments. Id.

236. I WORKS OF ALEXANDER HAMILTON 209 (Henry Cabot Lodge ed., 1904) (hereinafter HAMILTON, WORKS]; see also THE FEDERALIST No. 15, at 112 (Alexander Hamilton) (Clinton Rossiter ed., 1961) (decrying that "the measures of the Union have not been executed"); THE FEDERALIST No. 46, at 174 (James Madison) (Clinton Rossiter ed., 1961) (noting that "federal administration [was] . . hitherto very defective in comparison with what may be hoped under a better system"). Historian Leonard White observes that the "government of the Confederation had steadily run down until its movements had almost ceased." LEONARD D. WHITE, THE FEDERALISTS 1 (1948).

237. I HAMILTON, WORKS, supra note 236, at 209.

238. Id. at 209-10.

239. LEARNED, supra note 223 , at 49 ; THACH, supra note 82 , at $70-71$.

240. See SANDERS, supra note 225 , at 95.

241. LEARNED, supra note 223, at 50.

242. Id. at 51 .

243. Id. at 51-52.

244. Id. at 51: ForRest MCDONALD, NOVUS ORDO SECLORUM: THE INTELlECTUAL ORIGINS OF THE CONSTITUTION 181 (1985) [hereinafter MCDONALD, NOVUS ORDO SECLORUM] (discussing feelings of delegates to Philadelphia Convention toward monarchy); see also THACH, supra note 82, at 80 (noting monarchic sentiment was present at Philadelphia Convention). 
power" enabling it to superintend the administration of federal law. ${ }^{2+5}$ Second, under this authority Congress continually experimented with administration, moving from special committees to standing committees, and finally to Secretaries, all the while retaining and wielding ultimate control. ${ }^{2+6}$ Finally, in response to the inadequacies of congressional control of administration, some individuals sought the creation of an independent Chief Executive who would be responsible for administration of federal law.

The Philadelphia Convention presented the opportunity to establish an energetic, independent Executive. Congress could be freed from executive details and concentrate on legislating, the proper function of a legislative body. As we shall see in the next Part, the Constitution's clauses relating to the President were drafted and ratified to energize the federal government's administration and to establish one individual accountable for the administration of federal law.

\section{THE PRE-RATIFICATION UNDERSTANDING OF THE PRESIDENT'S Role IN THE ADMINISTRATION OF FEDERAL LAW}

With this background understanding in mind, we turn to the pre-ratification historical context of the constitutional provisions discussed in Parts II and III. In keeping with the originalist methodology laid out in Part I, we start with the pre-ratification understanding of the Constitution, saving the post-ratification interpretations for Part VI. The pre-ratification history reveals that the textual understandings advanced in Part III were widely held at the time the Constitution was being debated and ratified. The background of the Executive Power Clause indicates that, at a minimum, the Clause was understood to grant the President the power to administer federal law. The Take Care Clause underscores the President's preeminent role in the execution of federal law; the Clause may also command "faithful" presidential execution and thus preclude any imagined presidential authority to suspend laws. The Necessary and Proper Clause detracts not a whit from these interpretations as nothing in its history suggests that it permits Congress to determine who will possess powers already granted in the Constitution. The Clause only permits Congress to enact laws to help itself and other branches implement their respective authorities. Given that the President has the constitutional authority to execute federal law, the Opinions Clause is probably superfluous, as the Executive Power Clause encompasses the authority to demand opinions of those statutorily charged with executing federal law. But if one considers redundancy an interpretational sin,

245. Indeed. Jerrilyn Marston has argued that Congress was onginally an executuve body that only gradually developed legislative attributes. The King's powers went to Congress. while the states wielded the powers of Parliament (like taxation). See JerRILYN MARSTON. KING \& CONGREsS 297-309 (1987).

246. See Gerhard Casper, An Essay in Separanon of Powers: Some Early Versions and Practices. 30 WM. \& MARY L. REV. 211,219 (1989). 
the Clause can be understood as restricting the President's power to demand opinions to those subjects relating to the statutory responsibilities of the officer.

In the course of examining the original understandings of these provisions, we will revisit two interesting textual puzzles posed by Lessig and Sunstein. First, they focus on who may exercise the nation's "administrative power." May Congress determine who shall exercise such power, as they contend, or does the Constitution already confer administrative authority to one of the three branches? The evidence adduced below affirms our textual claim that the Constitution's grant of the executive power includes the authority to administer federal law and thus that the President already possesses the "administrative power."

Second, Lessig and Sunstein consider whether the Constitution distinguishes between "Heads of Departments" and "principal officers in the Executive Departments." In other words, does the Constitution implicitly recognize that there are two types of departments-executive departments with principal officers, and nonexecutive, administrative departments led by department heads? As we surmised earlier, ${ }^{247}$ none of the Framers or ratifiers regarded the differences between the terms "Heads of Departments" and "principal officers" as meaningful at all. In fact, none seemed cognizant of this difference. Instead, individuals in charge of departments were variously identified as heads, principal officers, ministers, and, of course, secretaries. Whatever they were called, however, they were understood to be the President's subordinates. Anyone statutorily required to execute federal law (i.e., executive officers) was to be an assistant to the Chief Executive. And, prior to ratification, no one distinguished between executive departments and administrative departments. All departments that would be charged with administration of federal law would be executive ones.

\section{A. The Executive Power Clause and the Administrative Power}

As noted earlier, Lessig and Sunstein claim that the Executive Power Clause merely indicates that one individual, rather than three, possesses the prerogatives granted in Article ${ }^{2}{ }^{248}$ Yet their view fails to account adequately for the prevalent understanding of what it meant to vest "the executive power." An examination of history both before and during the Constitution's framing and ratification will demonstrate that it was well understood at the time of the Constitution's ratification that the executive power, at a minimum, consisted of the power to control law execution. And although Lessig and Sunstein attempt to unearth historical support for their

247. See supra part II.C.

248. Lessig \& Sunstein, supra note I, at 54. 
notion that the founding generation believed in an administrative power to be allocated by Congress, we remain unconvinced. To our knowledge, no one ever mentioned anything resembling the administrative power. Indeed, as expected, whenever administration is mentioned, it is discussed in the context of the President's superintending role.

\section{Political Theorists: Locke, Blackstone, and Montesquieu}

To frame the historical context of the Constitution's Executive Power Clause, let us commence with an extremely brief examination of the familiar theorists John Locke, Sir William Blackstone, and Montesquicu, all of whom understood the executive power to be the authority to execute laws. In his Second Treatise of Civil Government, John Locke confirmed this elementary point:

[B]ecause the Laws ... have a constant and lasting force, and need a perpetual Execution, or an attendance thereunto: Therefore 'tis necessary there should be a Power always in being, which should see to the Execution of the Laws that are made, and remain in force. And thus the Legislative and Executive Power come often to be separated. $^{249}$

Blackstone, writing more than a hundred years later in 1765 , held the same understanding of the executive power. In tyrannical governments, the absolute monarch ("the supreme magistracy") possessed the rights "of making and of enforcing the laws." Yet where the legislative and executive authority are separated, "the former will take care not to entrust the latter with so large a power, as may tend to the subversion of it's [sic] own independence."2so Montesquieu similarly claimed that "[w]hen the legislative and executive powers are united in the same person .... there can be no liberty; because apprehensions may arise, lest the same monarch or senate should enact tyrannical laws, to execute them in a tyrannical manner."2sI All three confirm that the executive power is principally about executing the law. ${ }^{252}$

249. John LOCKE, THE SECOND TREATISE OF CIVIL GOVERNMENT $\$ 144$ (J.W. Gough ed., 1948) (4th ed. 1764).

250. 1 William Blackstone, Commentaries *142. Though Lessig and Sunstein cite Arthur Bestor's understanding of Blackstone's conception of executive power, see Lessig \& Sunstein, supra note 1. at 53. they omit any of Blackstone's own words regarding the meaning of the executuve power.

251. Charles de Secondat, Baron de MONTESquieu. Thie Spirtt of the Laws 185 (pholo. tepnnt 1984) (1751). Montesquieu also noted that "[m]iserable indeed would be the case" if one man or group of men were "to exercise those three powers, that of enacting laws, that of execuung the public resolutions. and that of judging the crimes ... of individuals." Id. at 186.

252. It is ironic that Lessig and Sunstein cite Jefferson's proposed Virgına Consututuon for the proposition that there is an administrative power of government, Lessig \& Sunstein. supra note 1. at 65. without recognizing that Jefferson, when he presented his draft in 1783. clearly contemplaled that execulton of the laws would be part of the Executive's functions. ".By executive powers.... [w]e give [the executives] those powers only, which are necessary to execute the laws (and administer the 
We also note that a separate administrative power has no basis in the political philosophers that so influenced the founding generation. Though he discusses at great length the powers of the British government, Blackstone fails to mention any administrative power to be allocated by Parliament. We also know that both Locke $^{253}$ and Montesquieu ${ }^{254}$ divided the universe of governmental powers into lists of three, although the content of Locke's list differed from that of the Framers. ${ }^{255}$ Neither of their lists mentioned an administrative power. This is significant because we also know, as Forrest McDonald has said, that "American republicans regarded selected doctrines of Montesquieu's as being virtually on a par with Holy Writ."256

McDonald goes on to say something more about the history and depth of the American attachment to a trinitarian taxonomy:

To appreciate Montesquieu's influence in America, it is useful to begin with the observation that in thinking of government, Americans followed a practice that was deep-seated in the Western world, namely, the almost mystical habit of thinking in threes. In part that habit may have stemmed from the concept of the Holy Trinity; in part it doubtless stemmed from Aristotle's division of forms of government into monarchy, aristocracy, and polity or constitutional democracy (with their counterpart evils-tyranny, oligarchy, and ochlocracy ... . ..$^{257}$

The point that should be taken away from all of this is that the founding generation firmly believed that, like Julius Caesar's Gaul, all of government came divided into three parts. Lessig and Sunstein's concept of a separate administrative power, to be parceled out by the legislature, simply did not fit into this framework.

government) . . .'" Monaghan, supra note 6, at 15 (quoting Thomas Jefferson, Proposed Constitution for Virginia, in 3 The WrITtNGS of Thomas Jefferson 320, 326 (Paul L. Ford ed., New York, G.P. Putnam's Sons 1894)). Jefferson would have labeled his executive the "Administrator" who, of course, had the power to execute. 1 The PAPERS OF ThOMAS JefFERSON 341 (Julian P. Boyd ed., 1950). We are indebted to John Yoo for this last point.

253. See generally LOCKE, supra note 249.

254. MONTESQUIEU, supra note 251 , at 185.

255. Locke believed that the three powers of government were the legislative, executive, and federative powers. In his view, the executive power encompassed what we think of as the judicial power. The federative power, however, by which Locke meant the government's international relations power, was separate and distinct. Lessig and Sunstein, by oddly insisting that the President has the power to control foreign affairs but not execution, seem to want to resurrect this Lockean typology and claim that the Framers really meant to give the President only the federative power and not the executive power, as the text of the Constitution says. See LOCKE, supra note $249, \$ 146$.

256. MCDONALD, NOVUS ORDO SECLORUM, supra note 244 , at 80.

257. Id. 


\section{Evidence from State Constitutions}

We are unaware of a single reference in any pre- 1787 state constitution to the existence of administrative power not already vested with the executive authority. There are, however, numerous texts from that era reaffirming that the universe of governmental powers is limited to three types-legislative, executive, and judicial. Consider, for example, the famous separation-of-powers clauses in many of the original state constitutions. Those clauses typically described the traditional three powers of government: legislative, executive, and judicial. The Virginia Constitution of 1776, for example, provided that "[t]he legislative, executive, and judiciary departments shall be separate and distinct, so that neither exercise the powers properly belonging to the other: nor shall any person exercise the powers of more than one of them, at the same time." 258 The Massachusetts Constitution of 1780 similarly provided:

[T] he legislative department shall never exercise the executive and judicial powers, or either of them; the executive shall never exercise the legislative and judicial powers, or either of them; the judicial shall never exercise the legislative and executive powers, or either of them; to the end it may be a government of laws, and not of men. ${ }^{259}$

Four other state constitutions contained analogous provisions: those of Georgia, Maryland, New Hampshire, and North Carolina. ${ }^{200}$ With this background of historical understanding, we believe that a separate category of administrative power to be apportioned by the legislature did not exist in the Framer's world: The Executive alone was empowered to execute all laws.

\section{The Philadelphia Convention}

In 1787, the orthodox understanding of executive power held by Locke, Blackstone, and Monstesquieu remained supreme, as the various constitutional blueprints presented to the Philadelphia Convention and discussed in the ensuing debates reveal continued use of the trinity of powers. ${ }^{261}$ The Virginia Plan, for example, envisioned a "National Executive," to be chosen by the legislature, who "besides [possessing] a general authority to execute the National laws," would "enjoy the Executive rights vested in Congress by the

258. VA. CONST. of 1776, reprinted in 10 SOURCES AND DOCUMENTS OF UNmed STATES CONSTITUTIONS $S 1$ (William F. Swindler ed., 1979).

259. MASS. CONST. of 1780 , reprinied in 5 SOURCES AND DOCUMENTS OF UNTED STATES CONSTITUTIONS, supra note 258 , at $92,96$.

260. MCDONALD, NovUS ORDO SECLORUM, supra note 244, at 84.

261. Indeed, one notes the striking similarity between our Executive Power Clouse, U.S. CoNST. an. II, $\S 1, \mathrm{cl} .1$, and Blackstone's assertion that "It]he supreme executive power of these kingdoms is vested by our laws in a single person, the king or queen," I WILLAAM BLACKSTONE, COMMENTARIES 183 . 
Confederation."262 The use of the word "besides" in the plan indicated that executing national laws was implicit in the duties of any Executive. Indeed, every plan put forth before the Convention recognized that execution of laws was a duty of the Executive, whether the Executive be unitary or ternary. ${ }^{263}$ Madison affirmed that "certain powers were in their nature Executive, and must be given to that departm[ent] whether administered by one or more persons." Accordingly, Madison proposed that the Executive(s) be authorized "to carry into effect[] the national laws." 264 Pennsylvania delegate James Wilson, perhaps the intellectual father of Article II's vigorous, independent Executive, ${ }^{265}$ similarly observed that the "only powers he conceived strictly Executive were those of executing the laws, and appointing the officers."266 In other words, the executive power was quintessentially about executing laws.

Delegates also echoed the separation-of-powers convictions of Locke, Blackstone, and Montesquieu. ${ }^{267}$ Madison observed that a legislatively appointed Chief Executive would be "dependen[t] . . on the Legislature, [and] would render [the Legislature] the Executor as well as the maker of laws; \& then according to the observation of Montesquieu, tyrannical laws may be made that they may be executed in a tyrannical manner."268 Obviously, the "Executor," i.e., the one who possessed the executive power, executed the laws. ${ }^{269}$

Philadelphia support for the existence of an "administrative power" is rather meager. Lessig and Sunstein focus on one James Madison-Charles Pinckney colloquy. ${ }^{270}$ Madison would have vested in the Executive(s) the power to "carry into effect the national laws ... [and] such other powers not legislative nor judiciary in their nature as may from time to time be delegated by the national Legislature."271 To Lessig and Sunstein, this proposal suggests that there is a fourth power of government, the administrative power. If only three powers were contemplated, and the President had the executive power, what nonlegislative and nonjudicial powers could Congress vest with

262. I Federal. CONVENTION, supra note 134, at 21 . Note that the Virginia Plan illustrates that tho Continental Congress possessed executive "rights." The Plan thus marked a radical departure from the Articles as it sought to grant those executive rights, formerly vested in Congress, to an independent Executive.

263. See generally Prakash, supra note 6, at $991,1000-04$.

264. I FEDERAL CONVENTION, supra note 134, at 67 (emphasis added).

265. See Prakash, supra note 6, at 998 n.42.

266. I Federal Convention, supra note 134, at 66. But see 4 Elliot's DEbates, supra note 53, at 119-20 (William R. Davie arguing that power of making treaties is executive).

267. See 1 FEDERAL CONVENTION, supra note 134, at 86 (Dickenson commenting on importance of keeping legislative, executive, and judiciary independent); 2 id. at 34 (Madison arguing same).

268. 2 id. at 34; see also THE FEDERALIST No. 47, at 302-03 (James Madison) (Clinton Rossiter ed., 1961) (making same point).

269. See Monaghan, supra note 6, at 16 (noting that although Philadelphia delegates were concerned with assertions of executive prerogative, they nevertheless constructed a "strong, legally and politically independent chief executive who could enforce national law").

270. Lessig \& Sunstein, supra note 1, at 64-65.

271. 1 FEDERAL CONVENTION, supra note 134, at 67 (internal quotation marks and brackets omitted), 
the President? Lessig and Sunstein argue that those powers must be something like the administrative power. ${ }^{272}$

Unfortunately, this syllogism has a faulty premise because it exaggerates the scope of the President's authority under Madison's proposal. Had Madison's plan vested the President with the executive power and then empowered Congress statutorily to vest authorities neither legislative nor judicial, Lessig and Sunstein's argument would be sound. But Madison's proposal did not envision a grant of the executive power. Instead, it would have granted only two authorities to the President: the power to execute federal law, and the appointment power. ${ }^{273}$ Madison's Executive(s) would have lacked many powers that belong to our President: the veto power, the pardon power, etc., many of which were historically understood to be authorities that Chief Executives possessed.

Far from contemplating administrative power, then, Madison's proposal envisioned situations in which Congress might elect to grant the President authority beyond the two powers specifically mentioned in his motion. Perhaps Madison wished to grant Congress the ability to furnish the Executive a veto, a power that was neither legislative nor judicial and thus could be properly granted to the Executive. Had Madison's clause become part of the Constitution, the provision would have sanctioned the granting of a line-item veto to the President. ${ }^{274}$

The point not to be lost, however, is that Madison's proposal did not grant the "executive power" to the President; consequently, Lessig and Sunstein's contention that Madison contemplated an "administrative power" in Philadelphia is simply based on a false premise. The argument is particularly suspect once one recognizes that Lessig and Sunstein's administrative power was already subsumed by Madison's grant to the Executive(s) of the authority to "carry into effect the national laws."

Even if one believed that Madison's proposal somehow implicitly contemplated something called an "administrative power" not vested by the Constitution in either Congress, the Executive, or the judiciary, an isolated statement in a summer-long convention is a slender reed upon which to rest the existence of a separate fourth administrative power of government to be allocated by Congress. ${ }^{275}$ Throughout the Philadelphia Convention, only three powers of the federal government were ever discussed: legislative, executive,

272. Lessig \& Sunstein, supra note 1, at 65.

273. James Wilson. at the Philadelphia Convention at least. thought that these two powers, appointments and execution, were the only ones "strictly executive." See I FEDERAL CoNvention, supro note 134 , at $65-66$.

274. Currently, Congress appears to lack the authority to grant a line-item veto to the President. Neither the Necessary and Proper Clause nor any other congressional power allows Congress to grant such authority. See supra part III.E.2.

275. We shall analyze Lessig and Sunsiein's interpretation of the Necessary and Proper Clause in the next Subsection. 
and judicial. ${ }^{276}$ Neither the Virginia, New Jersey, Pinckney, nor Hamilton plans mentioned an "administrative power." Nor did anyone suggest that Congress would have the authority to lodge the "administrative" power where Congress saw fit. The Constitution only identifies three types of federal powers because the delegates only recognized three powers.

\section{The Public Ratification Debates}

Moving from Philadelphia to the public ratification debates, we find confirmation, from both supporters and opponents of the Constitution, that the executive power includes the authority to execute the laws. The Anti-Federalist Brutus approvingly cited Montesquieu's influence on the constitutions of Massachusetts and Virginia, noting that they had heeded Montesquieu's admonition that the executive and legislative powers ought to be in distinct hands. ${ }^{277}$ Similarly, the Anti-Federalist William Symmes acknowledged that "there must be an Executive Power, independent of the legislature." Symmes, however, would have preferred an executive council. "The execution of the law requires as much prudence as any other department .... Yet [the President] has no council or assistant, no restraint" in exercising the executive power. ${ }^{278}$ Symmes quite clearly recognized that the essence of the executive power is the execution of law. ${ }^{279}$

James Wilson, speaking at the Pennsylvania ratifying convention, disagreed with Symmes about the desirability of an executive council. One of the best qualities of the Constitution was that "the executive authority is one .... The executive power is better to be trusted when it has no screen.... [W] well

276. On May 30, the Convention adopted a resolution stating that the "national government ought to be established consisting of a supreme legislative, judiciary and executive." I FEDERAL CONVENTION, supra note 134 , at 30 . After the Convention accepted this language on June 20 , see $I$ id. at 335 , the provision was sent to the Committee of Detail. The Committee reported the following language: "The Government shall consist of supreme legislative, executive, and judicial powers." 2 id. at 177. On August 7, the Convention approved the Committee's changes without debate. 2 id. at 209. This language was sent to the Committee of Style and Arrangement, $2 \mathrm{id}$. at 565, which eliminated it, probably because the beginning of the first three Articles already mentioned legislative, executive, and judicial powers and there was no need for a separate provision.

277. S THE COMPLETE ANTT-FEDERALIST 202 (Herbert J. Storing ed., 1981) [hereinafter ANTIFEDERALIST]. Brutus objected to the Constitution in part because the Senate had the power to confirm individuals and to pass treaties. He thought these powers properly belonged completely with the President. 5 id. at 203; see also 3 id. at 63 (Democratic Federalist observing that executive and legislative powers ought to be kept separate). But see 3 DOCUMENTARY HISTORY OF THE RATIFICATION, supra note 225, at 526 (citizen of New Haven asserting that legislative and exceutive powers should be kept separate in execution of laws but not in framing of laws).

278. 4 ANTI-FEDERALIST, supra note 277, at 60 . Symmes thus understood that the Chief Executive, unlike many state executives of that era, did not need to receive the concurrence of a council before deciding how to execute federal law. See Casper, supra note 246, at 217. In light of the exclusive grant of "the Executive Power" to the President, Symmes' understanding makes perfect sense.

279. Apart from this minimal understanding of the executive power, many Anti-Federalists viewed the Executive Power Clause as a grant of broad authority. See MCDONALD, AMERICAN PRESIDENCY, supra note 139. at 193. 
know what numerous executives are. We know there is neither vigor, decision, nor responsibility in them."280 Wilson's discussion of executive authority is an examination of who ought to superintend federal law execution. Who should be responsible for execution of the laws? Three executives, an executive encumbered by a committee, or a solitary executive? Wilson's answer was that one person, the President, was quite sensibly given the power to execute federal law. Likewise, Cincinnatus, drawing upon the political theorist De Lolme, urged that the "executive power should be in one," as a unitary Executive would be "indispensably necessary to effective execution."281

In the context of discussing the treaty power, Hamilton noted that " $[t]$ he essence of the legislative authority is to enact laws."282 At the same time, "the execution of the laws and the employment of the common strength, either for this purpose or for the common defense, seem to comprise all the functions of the executive magistrate."283 The Anti-Federalist Impartial Examiner observed that the President possessed the "supreme executive power," thus signifying that the term "executive power" had meaning other than as a shorthand for the powers listed in Article II. ${ }^{28 s}$ The founding generation therefore understood that the grant of the executive power included the authority to execute laws. ${ }^{285}$

280. 2 DOCUMENTARY History OF THE RATIFICATION, supro note 225, at 495. Indeed, when Wilson later addresses the salutary effects of having a "single magistrate," namely "strength. vigor, energy, and responsibility in the executive department," he refers agan to the execution of federal law. 2 ud. at 579

Note the interesting similarities between Wilson's comments at the Pennsylvania ralufyıng convention (and his earlier comments at the Philadelphia Convention. see I Federal CONvestios. supra note 134. at 65-66) and Blackstone's comments on the unitary Executive:

[The executive power] is wisely placed in a single hand by the Bntish consututuon, for the sake of unanimity, strength, and dispatch. Were it placed in many hands. it would be subject to many wills: many wills, if disunited and drawing different ways, create weakness in government: and to unite those several wills, and reduce them to one, is a work of more ume and delay than the exigencies of state will afford. The king of England is therefore not only the chicf. but properly the sole, magistrate of the nation: all others acting by commission from. and in due subordination to him ....

1 WILLIAM BLACKSTONE, COMMENTARIES *242-43.

281. 6 ANTI-FEDERALIST, supra note 277, at 22.

282. The Federalist No. 75, at 450 (Alexander Hamilon) (Clinton Rossiter ed.. 1961).

283. Id.

284. 5 ANTI-FEDERALIST, supra note 277, at 194. It makes little sense to contend that when the Impartial Examiner was referring to the "supreme execultve Power." he was referming to the supreme powers to veto, negotiate treaties. etc. These are nol "supreme" powers. In contrast, since the President is the only individual granted the executive power, he controls those individuals statulonly authonzed to execute and is thus "supreme" with respeet to them. He ts the Supreme or Chief Execulive. See also 5 id. at 167 (Republicus noting that Article II. Section 1 vested "the supreme conlunental executuve power in a president").

285. Once again, we have come across no comments esther from supporters or opponenis of the Constitution that recognize the existence of an administratuve power to be apportioned by Congress. 


\section{Lessig and Sunstein's Historical Arguments for Not Treating the Vesting Clause of Article II as a Vesting Clause}

Lessig and Sunstein make three arguments against the notion that the Executive Power Clause actually vests a power. First, they assert that although "he was . . . quite eager to define a strong executive," Alexander Hamilton did not so describe the Clause in his famous Article II essays in The Federalist. ${ }^{286}$ In Hamilton's "catalog of the executive powers, contrasting the American executive with the British monarch, nowhere does he discuss a general executive power arising from the Vesting Clause."287 This claim suffers from several flaws.

It is at least debatable whether or not Hamilton's Federalist essays offered a broad view of the Executive Power Clause. Forrest McDonald, for instance, has argued that when Hamilton listed those functions that are within the purview of the executive department, ${ }^{288}$ Hamilton embraced the idea that the Executive Power Clause actually vests a power. ${ }^{289}$ But suppose Lessig and Sunstein's reading of The Federalist is correct. That reading ignores the fact that Hamilton wrote his Federalist essays on the presidency in order to quiet the concern of the Anti-Federalists, ${ }^{290}$ who were worried that the Chief Executive would become a king. Given the urgency of obtaining New York's assent to the Constitution, is it really so surprising, in light of what Hamilton believed to be vicious "misrepresentation[s]" by the "writers against the Constitution,"291 that he might have downplayed the importance of the Executive Power Clause? ${ }^{292}$ Hamilton was eager to define a strong Executive at Philadelphia, but when it came to the ratification debate, he did his best to downplay the aspects of presidential power that might jeopardize ratification. ${ }^{293}$

286. Lessig \& Sunstein, supra note 1, at 49 .

287. Id.

288. See The Federalist No. 72, at 435-36 (Alexander Hamilton) (Clinton Rossiter ed., 1961).

289. MCDONALD, AMERICAN PRESIDENCY, supra note 139, at 206.

290. Consider, for example. Hamilton's colorful description of the Anti-Federalist view of the presidency recounted in No. 67 :

He has been decorated with attributes superior in dignity and splendor to those of a king of Great Britain. He has been shown to us with the diadem sparkling on his brow and the imperial purple flowing in his train. He has been seated on a throne surrounded with minions and mistresses, giving audience to the envoys of foreign potentates in all the supercilious pomp of majesty. The images of Asiatic despotism and voluptuousness have scarcely been wanting to crown the exaggerated scene. We have been almost taught to tremble at the terrific visages of murdering janizaries, and to blush at the unveiled mysteries of a future seraglio.

THE Federalist No. 67, at 407-08 (Alexander Hamilton) (Clinton Rossiter ed., 1961).

291. Id. at 407.

292. McDonald notes that many Federalists belittled federal power, especially the President's. See MCDONALD, AMERICAN PRESIDENCY, supra note 139, at 184.

293. Finally, it might be of some relevance to note that Hamilton, in his now-famous defense of President George Washington's Neutrality Proclamation, explicitly contended that the Executive Power Clause is a grant of "the executive Power" that is further defined by the subsequent provisions of Article II. See Monaghan, supra note 6, at 21 . It is thus ironic that Lessig and Sunstein would claim that "not even 
Second, Lessig and Sunstein attempt to draw on state constitutions to prop up their theory that the Executive Power Clause vests no power. Pointing to an Illinois Supreme Court decision, they claim that "the same language vesting executive power in state constitutions had been understood at the time of the framing not to mark an inherent power." ${ }^{294}$ There are several difficulties with relying upon Field v. People ex rel. McClernand. ${ }^{295}$ Illinois was not even in existence at the time of ratification and any opinion regarding a state constitution that was issued more than fifty years after ratification of the federal Constitution necessarily has little bearing on the original understanding of that document. Virtually everyone who participated in ratifying the Constitution was dead by the time the Illinois Supreme Court decided that case. ${ }^{296}$ If the founding generation acknowledged that vesting clauses lacked any substantive content, surely more relevant and contemporaneous evidence would exist. Dubious reliance on an Illinois Supreme Court opinion from 1839 construing "a similar vesting clause" simply cannot overcome the mountain of contrary textual and historical evidence. ${ }^{297}$

Third, the Virginia Declaration of Rights does not help Lessig and Sunstein's case either. They rightly note that the 1776 Virginia Declaration weighs against claims of "inherent [governmental] powers by anyone." ${ }^{\text {"98 }}$ But that is not an argument against the notion that the Executive Power Clause vests power with the President. As noted earlier, our claim is not that Article II, Section 1 vests "inherent power" in the President. ${ }^{299}$ We only assert that it vests the authority to control the administration of federal law. This is not a claim of inherency; it is an assertion linked to the Constitution's text. We maintain that the executive power means, at a minimum, the power to control execution of the laws. If this amounts to an argument for inherent executive powers, so is the claim that the President enjoys a pardon power. But that is nonsense. In either case, there is a textual basis for the assertion, and thus no inherency claim is being made at all. Accordingly, the Virginia Declaration is simply inapposite to a discussion of the meaning of Article II, Section 1.

Hamilton described the Vesting Clause as an independent source of substantive executive power." Lessig \& Sunstein, supra note 1 , at 49.

294. Id. at 49-50.

295. 3 Ill. (2 Scam.) 79 (1839).

296. Moreover. in the wake of "King" Andrew Jackson's highly controversial Administraution. conceptions about the desirability of powerful Executives may have shifted markedly from what they had been in 1787 . These new views and not the original understanding may have motivaled the Illinois Supreme Court.

297. Lessig \& Sunstein, supra note 1, at 119 n.206.

298. Id. at $119 \mathrm{nn}$. 206-07.

299. See supra note 93. 


\section{Administration and the Chief Administrator}

Throughout this Section, we have presented evidence that the executive power is the power to execute the law. We have maintained that there is no administrative power to be apportioned by Congress. Yet one must be careful not to conclude mistakenly that the founding generation never discussed the concept of "administration." In fact, that notion was extensively addressed-but only in the context of the President's preeminent administrative role. "Administration" was used interchangeably with the term execution, both tied to the Executive. For instance, James Wilson objected to a plan creating three executives, declaring that it would produce "uncontrouled, continued, \& violent animosities; which would . . . interrupt the public administration." 300 Similarly, South Carolinian John Rutledge thought a single man would "administer the public affairs best." 301

The President's preeminent administrative role is also highlighted in The Federalist. Hamilton affirmed that "energy in the Executive is a leading character in the definition of good government ... [and] is not less essential to the steady administration of the laws." 302 Referring later to steady administration, Hamilton noted that "[d]uration in office" relates to "the personal firmness of the executive magistrate ... and to the stability of the system of administration which may have been adopted under his auspices." 303 Hence, allowing the President more than one term would "secure . . . the advantage of permanency in a wise system of administration." ${ }^{304}$ Arguing against annexing a council to the President, Hamilton maintained that an "artful cabal" within the council would, by making the Executive sluggish and confused, "enervate the whole system of administration." 305

300. I FEDERAL CONVENTION, supra note 134, at 96. Wilson's statement indicates that the Executive would occupy a critical role in "administration." Note that Wilson recognized that the Exccutive would execute the laws, see 1 id. at 66 , so when he speaks of the public administration, he refers to the Executive's administration of laws.

301. $1 \mathrm{id}$. at 65 . James Monroe also commented that the "Executive is that upon which ... we should rest our hopes, for an equal, a federal, and a wise administration." 9 DOCUMENTARY HISTORY OR THIB RATIFICATION, supra note 225, at 863-64. Not everyone agreed with these sentiments. The Anti-Federalist essayist, Philadelphiensis, complained that "our laws are to be administered by this tyrant," referring to the President. $16 \mathrm{id}$. at 58.

302. THE FEDERALIST No. 70, at 423 (Alexander Hamilton) (Clinton Rossiter ed., 1961) (emphasis added); see also THE FEDERALIST No. 68, at 412 (Alexander Hamilton) (Clinton Rossiter ed., 1961) (noting that President would have important role "in the administration of the government"); id. at 414 (commenting on critical role "the executive in every government must necessarily have in its good or ill administration").

303. THE Federalist No. 71, at 431 (Alexander Hamilton) (Clinton Rossiter ed., 1961).

304. THE Federalist No. 72, at 436 (Alexander Hamilton) (Clinton Rossiter ed., 1961); see also id. at 439 (claiming that an "ill effect of the exclusion would be that it would operate as a constitutional interdiction of stability in the administration").

305. The Federalist No. 70, at 427 (Alexander Hamilton) (Clinton Rossiter ed., 1961). 
Though Lessig and Sunstein cite Hamilton's most forceful statement on the President's relationship to administration, they fail to draw the fairly obvious conclusions: "The administration of government ... is limited to executive details, and falls peculiarly within the province of the executive department." 306 What constitutes "administration?" Hamilton sketched briefly: command of foreign negotiations, preparation of a budget, spending appropriations, direction of the army and navy, direction of a war, "and other matters of a like nature." 307 Hamilton drew no distinction between what Lessig and Sunstein label "executive" functions, such as foreign affairs and military matters, and "administrative" functions, such as spending appropriations. Rather, these functions were thrown together in a long list, all of them granted to the "executive department." If any doubts remain, Hamilton unequivocally lays them to rest: "The persons, therefore, to whose immediate management these different matters are committed ought to be considered as assistants or deputies of the Chief Magistrate, and on this account they ought to derive their offices from his appointment . . . and ought to be subject to his superintendence." 308 Administrative assistants (executive officers if you will) are mere deputies of the Executive Magistrate and are subject to his "superintendence."

Lessig and Sunstein observe that to "modern readers 'administrative' and 'executive' are just the same idea." 309 Though they insist that this "modern sense of 'administration' is quite new,"310 they also acknowledge that Hamilton used the term in the same sense they used it." As the above evidence establishes, the modern reader who considers administration and execution to be one and the same treats those words in the exact manner that the founding generation used them. The "modern" sense of administration is identical to its eighteenth-century counterpart. ${ }^{312}$

306. THE Federalist No. 72, at 435 (Alexander Hamilton) (Clinton Rossiter ed., 1961).

307. Id. al 435-36.

308. Id. at 436 (emphasis added).

309. Lessig \& Sunstein, supra note I, at 44.

310. Id. at 41 n. 177 .

311. Id. at 53 n. 216 .

312. Lessig and Sunstein spend a good deal of time examining "nineteenth-century" views on the differences between administrative and exceutive power. Id. at 43-6I. Most of their soures, however, were authored in the early 20 th century, reflecting the progressive ideology of placing executuon "above politics." Rather than expending so much energy to make sense of these 20th century constututional theorists, they should have attempted to discern the founding generation's actual understanding of administration and who would control it. After all, Lessig and Sunstein identify their task as determining the onginal understanding of constitutional text at the time of ratification, not the understanding of theonsts over 130 years later-theorists who were reading the text with decidedly modem presuppositions and sensibilities. 


\section{B. The Take Care Clause}

There was a remarkable consensus at the Philadelphia Convention that the President would be empowered to execute all federal law. ${ }^{313}$ Lessig and Sunstein, while acknowledging that such a consensus originally existed, contend that the Convention's adoption of the Necessary and Proper Clause marked a departure from that consensus. In their account, Philadelphia delegates initially agreed that the President would have "a broad claim for implied power to 'carry into execution' the laws of the Nation, which power must include something like what we would today conceive of as administrative power." ${ }^{134}$ Indeed, the Committee of Detail received language stating that the President was to have the power "to carry into execution the national laws." 315 What emerged from the Committee, however, were variants of the Take Care and Necessary and Proper Clauses we recognize today. The Necessary and Proper Clause, Lessig and Sunstein assert, represents a rejection of the claim that the President has the constitutional authority to execute all federal law. The Take Care Clause, on their reading, compels the President to respect the manner in which Congress has, pursuant to the Necessary and Proper Clause, apportioned the power to administer laws that Congress enacts. ${ }^{316}$ Thus, should Congress create an independent Treasury, the President must take care to respect its autonomy.

As Lessig and Sunstein's argument about the relationship between the Take Care and the Necessary and Proper Clauses is premised on a supposed last-minute rejection by the Philadelphia Convention of granting to the President the constitutional authority to administer laws, an examination of the Philadelphia history will not prove useful. ${ }^{317}$ The more important question to resolve is whether the ratifiers understood that the execution of all federal law was constitutionally delegated to the President. After all, they discussed who would administer the law in the shadow of both Clauses. Surely if the Necessary and Proper Clause permitted Congress to vest the power to execute the laws in whomever it saw fit, and the Take Care Clause required the President to accede to any and all such administrative delegations, the postframing public debate would reflect that truth. Since there is no special relationship between the two Clauses either textually, or, as we shall see, historically, we treat them separately, dealing with only the Take Care Clause here. Many regarded the Clause as empowering the President to execute

313. See Prakash, supra note 6, at 1002-03.

314. Lessig \& Sunstein, supra note I, at 69 . Note that Lessig and Sunstein acknowledge that their "administrative" power is really the power to execute federal law.

315. 2 FEDERAL CONYENTION, supra note 134, at 32.

316. 2 id. at 69.

317. 2 id. at 66 . The Philadelphia history of the Take Care Clause can be found in Prakash, supra note 6 , at 1000-03. 
federal law. A few remarked that the Clause created a duty. But no one ever stated that the Clause would force the President to respect congressional wishes about who ought to superintend the administration of certain "administrative" laws. The Constitution had already decreed that all laws were to be executed by the Chief Executive and his executive officers.

\section{The State Ratification Debates}

State debates uniformly demonstrate that the President was vested with the authority to execute all federal law. At the Virginia convention, Governor Edmund Randolph approvingly commented upon the Constitution's decision to vest authority to administer the laws in one Executive: "All the enlightened part of mankind agree that the superior dispatch, secrecy, and energy with which one man can act, renders it more politic to vest the power of executing the laws in one man." ${ }^{318} \mathrm{He}$ thus confirmed that the whole debate regarding whether to have one or three executives revolved around whether one or three ought to have the power to administer the law. ${ }^{319}$ Randolph also criticized those who thought the President had extraordinary and overwhelming powers. What are the President's powers? One uncontroversial prerogative was " $[t] 0$ see the laws executed. Every Executive in America has that power." ${ }^{\text {"320 }}$

James Wilson, addressing the Pennsylvania ratifying convention, tallied up presidential powers that could be exercised independent of the Senate. After noting that the President was Commander in Chief and could pardon, Wilson asserted that "[t]here is another power of no small magnitude intrusted to this officer. 'He shall take care that the laws be faithfully executed." 321 William McClaine, speaking at the North Carolina ratifying convention, observed that the Take Care Clause, one of the Constitution's "best provisions," ensured a vigorous execution of federal law.

If he takes care to see the laws faithfully executed, it will be more than is done in any government on the continent; for I will venture to say that our government, and those of the other states, are, with respect to the execution of the laws, in many respects mere ciphers. $^{322}$

McClaine thus expressed his hopes for energetic presidential execution.

318. 9 DOCUMENTARY HISTORY OF THE RATIFCATION, supra note 225. al 1097-98.

319. See generally Prakash, supra note 6, at 998-1000.

320. 9 DOCUMENTARY HISTORY OF THE RATIFICATION, supra note 225. al 1098 (emphasis added). Randoiph also observed that when Congress provided the authority to call forth the milita to execute the laws, the President would control it. 3 ELLIOT'S DEBATES, supra note S3, at 400-01: see LI.S. CONST. ant II. $\& 2, \mathrm{cl}$. 1 .

321. 2 ElLiOT'S DeBATES, supra note 53, at 513.

322. 4 id. at 136. 


\section{The Public Debate Outside the Conventions}

In The Federalist No. 77, Hamilton likewise affirms that one of the "powers of the executive" lies in "faithfully executing the laws." also attempted to answer the criticisms of those who argued that the President would frequently use the militia to enforce federal law by remarking that the President could instead call upon the people to help him execute the law. Some were worried that there was no "provision in the proposed Constitution for requiring the aid of the Posse Comitatus to assist the magistrate in the execution of his duty [namely executing federal laws]." ${ }^{324}$ Yet, though there was no specific provision authorizing the use of the posse like there was for the militia," ${ }^{325}$ "[i]t would be absurd to doubt that a right to pass all laws necessary and proper to execute its declared powers would include that of requiring the assistance of the citizens to the officers who may be intrusted with the execution of those laws." 326 In other words, Congress could utilize the Necessary and Proper Clause to "assist" the Chief Magistrate and his subordinate magistrates, who were "entrusted" with the execution of laws. ${ }^{327}$

Hamilton's use of the word "magistrate" in the above context is significant. As Mr. Prakash has argued elsewhere, the authors of The Federalist Papers employed the term magistrate to refer to individuals who execute law. ${ }^{328}$ Repeatedly, Madison and Hamilton refer to the President as the Magistrate, Chief Magistrate, and the Supreme Executive Magistrate. ${ }^{329}$ Thus, they recognized that because the President was the nation's Chief Magistrate he would command all those statutorily charged (inferior magistrates) with enforcing federal law. ${ }^{330}$

Other Federalists, writing in newspapers or authoring pamphlets, had similar understandings. Noah Webster compared the President to the supreme magistrates of Rome. He claimed that the "annual popular election of executive officers" was the "source of a negligent, partial and corrupt administration," as a "lax execution of the laws" occurred when the Executive was dependent

323. THE FEDERALIST No. 77, at 463 (Alexander Hamilton) (Clinton Rossiter ed., 1961).

324. THE FEDERAlist No. 29, at 183 (Alexander Hamilton) (Clinton Rossiter ed., 1961).

325. U.S. CONST. art. I, $\$ 8, \mathrm{cl} .15$.

326. The Federalist No. 29, at 183 (Alexander Hamilton) (Clinton Rossiter ed., 1961).

327. Hamilton thus confirms the proposition that the Necessary and Proper Clause can be used to assist the President in implementation of his constitutional powers and duties.

328. See Prakash, supra note 226, at 1961 n.26. A magistrate is "an executor of laws." 2 JoHNSON's DICTIONARY, supra note 116, at 1186; see also 6 OXFORD ENGLISH DiCTIONARY, supra note 145, at 27 (magistrate is "a civil officer charged with the administration of the laws").

329. With the assistance of THE FEDERALIST CONCORDANCE (Thomas S. Engeman et al. eds., 1988), we count at least 16 references to the President as the "Magistrate," 15 uses of "Chief Magistrate," and at least three uses of "Supreme Executive Magistrate." This confirms The Oxford English Dictionary's claim that the title "Chief Magistrate, first Magistrate" is used in a monarchy to refer to the sovercign; "in a republic, usually the President." 6 OXFORD ENGLISH DictionaRY, supra note 145, at 27.

330. Contrary to Lessig and Sunstein's assertion, see Lessig \& Sunstein, supra note 1, at 63 n.258, a reading of The Federalist indicates that Hamilton emphasized that execution of the laws is a power of the President. See supra text accompanying note 323. 
"on the popular voice." 331 In all free countries, "where law's govern, and not men, the supreme magistrate should have it in his power to execute any law, however unpopular, without hazarding his person or office." Fortunately, our chief magistrate was not subject to annual election and thus the nation could expect a more fair and even administration of federal law. ${ }^{332}$

Like James Wilson before the Pennsylvania convention. Americanus commented that the Senate could not interfere with the President's "mighty power[]" to "take care, that the laws be faithfully executed." A33 A Jerseyman was puzzled that anyone could oppose the Constitution's establishment of an independent Executive, arguing that it would be "highly ridiculous to send representatives ... to make laws for us, if we did not give power to some person or persons to see them duly executed." ${ }^{334}$ A Landholder (Oliver Ellsworth) echoed the oft-heard assertion that one Executive was desirable: "Secrecy, vigor, dispatch, and responsibility require that the supreme executive should be one person and unfettered, otherwise than by the laws he is to execute." 335

A review of Anti-Federalist writings yields still more evidence of universal acknowledgement that the President has the authority to execute all federal laws. The Federal Farmer shared the Landholder's belief that reason and experience had taught nations that "making laws" belonged to "numerous assemblies." The execution of these laws, however, was better left "to the direction and care of one man." One man "seems to be peculiarly well circumstanced to superintend the execution of laws with discernment and decision, with promptitude and uniformity." 336 Like Noah Webster and Alexander Hamilton, the Federal Farmer also thought that the "first executive magistrate ought to remain in office so long as to avoid instability in the execution of the laws." 337 Yet the Federal Farmer was not an unalloyed fan of Article II: He objected to providing the President with a veto since it "give[s] him a share in making the laws, which he must execute." 338

331. NoAh Webster, an EXamination into the leadiNg Princtples of the federal CONSTITUTION (1787), reprinted in PAMPHLETS ON THE CONSTIUUTON OF THE UNTED STATES. PUBLISHED DURING ITS DisCusSiOn BY THE PEOPLE, 1787-1788, at 36 (Paul L. Ford ed.. B. Franklin 1971) (1888) [hereinafter PAMPHLETS].

332. Id. at 36-37. Webster later observed that as the "supreme executive," the President was "invested with power to enforce the laws of the union." Id. at 65 .

333. 8 ANTI-FEDERALIST, supra note 277, at 203.

334. 3 id. at 149 .

335. 3 id. at 489 .

336. 2 id. at 310 . Other Anti-Federalists supported the creation of a Chief Admınistrator, thunking that he could restrain avaricious office seekers and ensure that both high and low felt "The ngor of equal law." 5 id. at 21 ; see 5 id. at 42.

337. 2 id. at 312 .

338. 2 id. at 314; see also 5 id. at 169 (Republicus complaining that President may exereise legislative and executive power in unparalleled manner). Not suprisingly. other Anti-Federalists favored the veto. A Federal Republican asserted that without the veto. Congress would know no limits. On the other hand, the President would be limited by the very existence of the laws. "IT] execute [laws] when made, is limited by their existence." 3 id. at 83. 
Just as in The Federalist Papers, essayists referred to the President as the "chief magistrate," $" 339$ the "single executive magistrate," "Supreme Executive."341 Brutus, when addressing the use of the militia to enforce federal law, asserted that " $[t]$ he magistrates in every government must be supported in the execution of the laws, either by an armed force . . or by the people." ${ }^{342}$ The Constitution, with its provision for calling the state militias to execute federal law subject to the direction of the Chief Magistrate, was no different.

\section{The Limits of the Take Care Clause}

As noted earlier, William Symmes affirmed that the Executive Power included the power to execute the laws. In his discussion of the Take Care Clause, Symmes posed some truly difficult questions relevant to our discussion:

Can we exactly say how far a faithful execution of the laws may extend? or what may be called or comprehended in a faithful execution? ... [S] hould the legislature direct the mode of executing the laws, or any particular law, is he obliged to comply, if he does not think it will amount to a faithful execution? For to suppose that the legislature can make laws to affect the office of President, is to destroy his independence, and in this case to supersede the very constitution. Is there no instance in which he may reject the sense of the legislature, and establish his own, and so far, would he not be to all intents and purposes absolute? ${ }^{343}$

Let us attempt to answer those questions.

The Committee of Detail added the requirement that the President "take care" that the laws be "faithfully" executed. ${ }^{344}$ What may have motivated them was a desire to prevent the President from declaring that his executive power granted him the ability not only to enforce federal law, but also to suspend federal law or suspend the execution of it. Until that time, the President had the power to "carry into execution the national laws."345 Recognizing that the newly created Executive Power Clause (which was drafted by the Committee of Detail at the same time it drafted the Take Care Clause ${ }^{346}$ ) already granted the President the authority to execute federal law,

339. 5 id. at 196 (comments of Impartial Examiner).

340. 3 id. at 82 (comments of A Federal Republican).

341. PAMPHLETS, supra note 331, at 329, 330 (comments of George Mason).

342. 2 ANT7-FEDERALIST, supra note 277, at 370.

343. 4 id. at 60-61.

344. See Prakash, supra note 6, at 1002.

345. 2 FEDERAL CONVENTION, supra note 134, at 32.

346. 2 id. at 171 . 
the Committee must have realized that the President did not need the authority to "carry into execution the national laws." Instead of eliminating the Clause, however, the Committee modified it by adding that the President would have to "take Care" that his execution of federal law would be "faithful."

But what of laws that usurp presidential power? Must the President faithfully enforce a federal law that he believes violates his constitutional authority? In other words, is the President obliged to comply with laws that "destroy his independence [or] supersede the very constitution?" w" Arguably, the President's oath to "faithfully execute the Office of the President" ws grants the President special authority to resist encroachments on his constitutional powers, as part of the duty in executing the office of the President might be to see that its powers are not infringed. ${ }^{3.49}$

We agree with Judge Easterbrook that the President must have a means of refusing to enforce laws that violate the supreme law of the Constitution, particularly where those laws usurp his constitutional prerogatives. We do not believe that the President must helplessly "take care" to execute (or abide by) a statute that takes away his constitutionally granted authority. It makes little sense to establish a Constitution with a President as Chief Executive and then

347. 4 ANTT-FEDERALIST, supra note 277, at 60-61.

348. U.S. CONST. art. II, §1, cl. 7.

349. See Easterbrook, supra note 162 (asserting that President has authonty to refuse to enforce laws that he feels are unconstitutional); see also Michael B. Rappapon. The President's Veto and the Constitution, 87 NW. U. L. REV. 735 (1993) (taking no position on constitutsonality of nonenforcement of existing laws, id. at 767 n.126, but arguing that President must velo any bill presented to him that is unconstitutional).

Moreover, perhaps part of the duty to "preserve, protect and defend the Constitution." U.S. CoNST. art. II, $\$ 1, \mathrm{cl} .8$, is to preserve, protect, and defend the powers of the President estublished in the Constitution. Thus the President might be constirutionally compelled to refuse to enfore or to abide by laws that impinge upon his constitutional powers even if he views such law's as polutucally expedient. If the President wanted to trade some of his constitutional powers or duties for the passage of legislation or some other legislative favor, obedience to his oath might prevent him from entenng into such a Faustran bargain. For a similar argument as to why federal courts must follow the Constitution rather than precedent, see Gary Lawson, The Constitutional Case Against Precedent, 17 HARV. J.L \& PUB. POL'Y 23 (1994).

One could also argue that laws that unconstitutionally impinge upon the President's powers are not really laws at all. In the context of the Supremacy Clause. Hamilon even claumed that states are only bound to recognize laws "made pursuant" to the Constitution. Laws that usurp the "residuary authonties of the smaller societies" are not laws that states must heed. THE FEDERALIST No. 33, at 20.t (Alexander Hamilton) (Clinton Rossiter ed., 1961). Although the President is not charged with execution only of laws made in pursuance of the Constitution, he may nevertheless be empowered consututuonally to ignore all laws he views as unconstitutional. Indeed, in the context of the Supremacy Clause. Hamilon noted that the limitation, "made pursuant" to the Constitution, would have been understood even if "thad not been expressed. Id. at 205. Perhaps the Presideni's Take Care Clause duties similarly contain an implicit understanding - the President must take care to faithfully execute only those laws consistent with the Constitution. More generally, whenever the Constitution speaks of laws, it might refer only to laws that are consonant with the Constitution. Hamilion's statement thus can be seen as sanctioning departmentalism. If a state or any branch of the federal government thinks the Congress has acted unconstututionally. It may refuse to accord a paricular federal law "supreme" status. Along the same lines. Easterbrook correctly notes that although the President must "take care" to execute the laws, the Constitution is itself a law, see U.S. CONST. art. VI, cl. 2 (describing the Constitution as "supreme Law"), and because the Constitution supercedes statutes, the presidential "take care" requirement applies to the Constutution first and foremost. Easterbrook, supra note 162, at 919; see Steven G. Calabresi, Thayer's Clear Mlistake. 88 Nw. U. L. REv. 269 (1993) (briefly describing and defending departmentalism). 
force that Chief Executive to relinquish his powers in the face of an unconstitutional statute. ${ }^{350}$ Easterbrook's reliance on James Wilson seems most appropriate here as well: "I say, under this constitution, the legislature may be restrained and kept within its prescribed bounds by the interposition of the judicial department . . . . In the same manner the President of the United States could shield himself and refuse to carry into effect an act that violates the constitution." 351 Any other interpretation would leave the Executive at the mercy of a determined, supermajority Congress or of a Congress that enacted such laws knowing that the next Executive would not be to its liking. ${ }^{352}$

Putting these extremely interesting and perplexing matters to one side, the important point is that everyone recognized that the President would administer federal law. Philadelphia and state convention delegates, Hamilton and Madison, other Federalists, and numerous Anti-Federalists understood this simple truth. Though Lessig and Sunstein claim that the Constitution grants Congress the authority to determine who can execute "administrative" law, no one examining the Constitution immediately after its framing articulated this understanding. Rather, speakers and essayists repeatedly proclaimed that the Constitution already granted the President the authority to execute federal law, a natural authority for one vested with "the Executive Power" and the duty to faithfully execute federal law. ${ }^{353}$

\section{The Necessary and Proper Clause}

As noted, Lessig and Sunstein assert that the Necessary and Proper Clause indicates that "Congress ... is vested with the power to determine how to structure the administration and how it is to function"354 and, more important, who will superintend the administration of particular laws. Their support for the perceived interrelationship of the Take Care and the Necessary and Proper Clauses rests on their reading of the Philadelphia Convention debates. The previous Section's review of pre-ratification history shows that,

350. Were there some textual basis for the notion that the President's powers could be withdrawn and/or allotted to someone else, it would be a different story.

351. Easterbrook, supra note 162, at 921 (citing PENNSYLVANIA AND THE FEDERAL CONSTITUTION OF 1787-1788, at 304-05 (J. McMaster \& F. Stone eds., Lancaster, Pa., Inquirer Printing \& Publishing Co. [888)).

352. We are aware that the founding generation considered the veto as a means of defending the President from congressional encroachments. See, e.g., THE FEDERALIST No. 73, at 442 (Alcxander Hamilton) (Clinton Rossiter ed., 1961). Nonetheless, the veto is a very imperfect defense. Should a united Congress pass laws that infringe upon the President's powers, the veto is of no avail. Moreover, a President who assumes office after a weak President may find many laws that unconstitutionally infringe upon his powers. Here also, a veto provides little protection.

353. Lessig and Sunstein maintain that the claimed significance of the Take Care Clause is strikingly modern. Lessig \& Sunstein, supra note 1 , at 63 . As the above evidence confirms, from the beginning, the Clause was understood to be central to the President's authority. Indeed, their footnote citing Madison and Ames, both of whom placed great significance on the Clause, vitiates the claim they make in the text. Id. at 63 n.254.

354. Id. at 68 . 
notwithstanding the Necessary and Proper Clause, opponents and supporters of the Constitution alike understood that the Philadelphia Convention had heeded what Lessig and Sunstein admit was the Convention's original impulse: vesting the power to execute laws in the President. This Section aims to highlight the historical support for our textual claims regarding the Clause. ${ }^{335}$

\section{The Clause Is About Providing the Means To Effectuate Powers of the Three Branches}

As we attempted to show in our textual discussion, the Clause is concerned with the means of effectuating the powers of the federal government, rather than with who may exercise certain powers. ${ }^{336}$ In discussing the Clause, Madison observed that "[n]o axiom is more clearly established in law, or in reason, than that wherever the end is required, the means are authorized." In other words, the Clause merely enables Congress to ensure that the powers of government can be effectively utilized and implemented. ${ }^{357}$

Indeed, the Philadelphia Convention passage that Lessig and Sunstein cite supports the notion that the Clause is concerned with means, the how of carrying powers into execution, not the who. Contrary to their assertion, ${ }^{358}$ Dr. McClurg did not object to the President's authority to execute the laws. In fact, McClurg acknowledged that the President would enforce the law: The Convention ought "to determine ... the means by which the Executive is to carry the laws into effect.... Is he to have a military force for the purpose [of executing federal law], or to have the command of the Militia?"'ss McClurg did not express even the slightest misgivings regarding the who of administration, namely presidential enforcement of federal law. Indeed, the only time we have found the Clause discussed in relation to the President is when Hamilton notes that the Clause may be used to enact laws enabling the President to call upon the posse comitatus to help enforce federal law. ${ }^{360}$

355. See supra part III.E.

356. THE FEDERALIST No. 44, at 285 (James Madison) (Clinton Rossiter ed., 1961). Hamilton aiso affirms that the Clause relates to means: "What is the ability to do a thing but the power of employing the means necessary to its execution? What is a LEGISLATIVE power but a power of making LAWS? What are the means to execute a LEGISLATIVE power but LAWS?" THE FEDERALIST No. 33. al 202 (Alexander Hamilton) (Clinton Rossiter ed., 1961). Hamilton thus confirms that the Cluuse is concemed with means. not with who exercises powers already granted by the Constitution.

357. This interpretation of the Clause may strike some as redundant. Hamilton and Madison proffered this interpretation, and they understood the Clause to be partially redundant. See THE FEDERALIST No. 33. at 202 (Alexander Hamilton) (Clinton Rossiter ed., 1961): THE FEDERALIST No. 44, at 285 (James Madison) (Clinton Rossiter ed., 1961).

358. See Lessig \& Sunstein, supra note 1, at $65-66$.

359. 2 FEDERAL CONVENTION, supra note 134, al 69 (emphasis added).

360. See The FEDERALIST No. 29, at 182-83 (Alexander Hamilton) (Clinton Rossiter ed., 1961). 


\section{Limitations on the Use of the Clause}

Hamilton's discussion of the posse in the context of the Clause highlights an explicit limitation found in the Clause: Laws enacted pursuant to the Clause must be supported by an independent grant of constitutional authority if they are to be regarded as "proper" and as "carrying into execution" a federal power. So, for instance, because the President lacks the authority to dispense titles of nobility, the Necessary and Proper Clause cannot be used to permit the President-to issue them. Thus Hamilton posed the following (at the time farfetched) hypotheticals:

Suppose, by some forced constructions of its authority . . . the federal legislature should attempt to vary the law of descent in any State, would it not be evident that in making such an attempt it had exceeded its jurisdiction and infringed upon that of the State? Suppose again that upon the pretence of an interference with its revenues, it should undertake to abrogate a land tax imposed by the authority of a State; would it not be equally evident that this was an invasion of that concurrent jurisdiction .... [to] tax which [the] Constitution plainly supposes to exist in the State governments? ${ }^{361}$

Similarly, because Congress lacks an independent source of authority for making administration of federal law autonomous of the President and because altering the Constitution's separation of powers is improper, the Clause is of no avail for those purposes. Congress could, however, pass laws authorizing the President to call forth the posse to help him execute federal law, because such laws would carry into execution a power of the federal government, namely the President's power to execute federal law.

\section{Prescient Warnings About the Possibilities of Abuse}

Madison realized that Congress might misconstrue the Necessary and Proper Clause and "exercise powers not warranted by its true meaning." In such circumstances, the "success of the usurpation will depend on the executive and judiciary departments, which are to expound and give effect to the legislative acts." 363 The Constitution's last line of defense was the people, who could elect more "faithful" representatives in order to "annul the acts of the usurpers." 364 Legislation stripping the President of his authority to superintend execution of law, enacted under the guise of the Necessary and Proper Clause, is exactly the type of usurpation that worried Madison.

361. The FeDERAlist No. 33, at 204 (Alexander Hamilton) (Clinton Rossiter ed., 1961).

362. THE FEDERALIST No. 44, at 285 (James Madison) (Clinton Rossiter ed., 1961).

363. Id. at 286.

364. Id. 
Naked attempts to alter the Constitution's delicate balance between the three branches ought to be recognized as examples of the legislative vortex attempting to suck up the powers of the Executive and the judiciary. ${ }^{365}$ Though Lessig and Sunstein admit that the Necessary and Proper Clause cannot be employed to legitimate "improper" laws, they never actually confront the question of what types of laws would be improper. Without an open discussion of the qualification "proper," their interpretation of the Clause appears to be a justification for constitutional authority enabling Congress to treat the Constitution's separation-of-powers provisions as mere default rules.

\section{Are We Still Under the Articles of Confederation?}

Indeed, the Lessig and Sunstein reading of the Necessary and Proper Clause effectively transforms the Constitution into a variant of the Articles of Confederation. Recall that under the Articles, Congress directed the administration and determined who would execute federal law; there was no Chief Magistrate who would oversee administration of all laws. ${ }^{366}$ Under Lessig and Sunstein's interpretation of the Necessary and Proper Clause, Congress once again (subject only to a presidential veto) can control the administration of federal law and decide who will execute it, notwithstanding the grant of executive power to the President. ${ }^{367}$ Their reading thus completely disregards central lessons of the Articles period, particularly the reaction of the unitary executivists to the Articles' failures. As we have seen, the Articles period, characterized by ineffective execution of federal laws, was one of the main catalysts behind the creation of a Chief Executive. Moreover, Lessig and Sunstein's interpretation fails to account for the many statements of the founding generation disparaging congressional control of execution. The Framers and ratifiers wished to get Congress out of the business of executive details and, to that end, established one individual constitutionally authorized to superintend administration. ${ }^{368}$

365. See The Federalist No. 48, at 309 (James Madison) (Clinton Rossiter ed.. 1961): The FEDERALIST No. 71, at 433 (Alexander Hamilton) (Clinton Rossiter ed., 1961). Federalist Alexander Hanson thought the Necessary and Proper Clause was entirely harmless. "I take the construction of these words to be precisely the same, as if the clause had preceded further and said. 'No act of congress shall be valid. unless it have relation to the foregoing powers, and be necessary and proper for carrying them into execution.'" PAMPHLETS, supra note 33I, at 234.

366. See supra part IV.

367. The only difference is that Lessig and Sunstein would agree that the President has the appointment power (subject to senatorial confirmation). Under the Articles. Congress did not need to wait for a nomination-it could appoint anyone it desired.

368. The Lessig and Sunstein rendition of the original understanding, it seems to us, ignores that one of the Constitution's radical features was the creation of a "strong and energetic exceutive authority." ForRest MCDONALD, THE PRESIDENCY OF GeORGe WASHINGTON 2 (1974) ihereinafter MCDONald. PRESIDENCY OF GEORGE WASHINGTON]. 
Though Lessig and Sunstein distinguish between executive laws and administrative laws, ${ }^{369}$ we find no one of the founding generation who even hinted at such a distinction. Instead, execution of all federal law was to be superintended by the Supreme Executive Magistrate. Pre-ratification, no one maintained that the Necessary and Proper Clause granted Congress the power to determine who would administer federal law, because administration and execution of the laws were considered to be one and the same, that is, part of the President's executive power.

This extensive postframing, pre-ratification survey illustrates that it was universally understood that the Constitution empowered the President to execute all federal laws. Given the dubious textual argument and the lack of any historical support, we ought not to embrace a reading of the Necessary and Proper Clause that gives Congress carte blanche to create numerous executives independent of the President, notwithstanding the Constitution's grant of executive power to the President. ${ }^{370}$

\section{The Opinions Clause, Principal Officers, and Department Heads}

\section{The Two Interpretations of the Opinions Clause}

Lessig and Sunstein have one final textual argument for the notion that "administrative power" may be vested in nonexecutive, administrative departments: the textual differences between the Opinions and the Inferior Officers Appointments Clauses. Driven by a desire to provide a nonredundant interpretation of the Opinions Clause, they dismiss Hamilton's acknowledgment of its redundancy ${ }^{371}$ and instead offer two interpretations of the Clause that construe it as nonsuperfluous.

Their more radical interpretation draws upon the observations of historian James Hart and relies upon the differences between the Opinions Clause and the Inferior Officers Appointments Clause. ${ }^{372}$ The Opinions Clause only permits the President to demand written opinions from a "principal Officer in each of the executive Departments." In contrast, the Inferior Officers

369. Lessig \& Sunstein, supra note 1, at 46. Recall that executive laws are those laws enacted to carry into execution executive powers found in Article II. Administrative laws are laws that seck to carry into execution administrative powers of Congress found in Article 1. Id. The Lessig and Sunstein thesis boils down to this: The President must administer "executive" Jaws, but has no constitutional right to superintend the execution of "administrative" laws. Such distinctions were simply absent at the Founding.

370. Given Lessig and Sunstein's invocation of the Holmesian maxim (dogs do not bark where thero is nothing of significance happening), see id. at $49 \mathrm{n.204}$, one would think that they would be reluctant to make claims regarding the import of the Necessary and Proper Clause, see id. at 64 . There was simply very little debate at the Philadelphia Convention regarding this Clause, thus suggesting that no one considered this power to be of great moment. If Lessig and Sunstein want to apply this maxim to the meaning of Executive Power, they ought to apply it with equal force to all similarly situated constitutional provisions.

371. Id. at 32.

372. See JAMES HART, The AMERICAN PRESIDENCY in ACTION: 1789, at 242-43 (1948). 
Appointments Clause permits Congress to vest appointment authority in the "Heads of Departments." Given the differences in wording, the Constitution might differentiate between executive departments, governed by heads, and executive departments, led by principal officers. In fact, Lessig and Sunstein maintain that the First Congress appreciated this distinction between "principal officers" (found in the statutes establishing the Secretaries of War and Foreign Affairs) and "heads of departments" (found in the Treasury Act). ${ }^{33}$ They contend that if all departments and officers were alike, there would be no need for the Constitution or Congress to distinguish between department heads and principal officers. Thus, though the President may demand opinions from officers in executive departments, he may not do so from officers in nonexecutive departments.

Lessig and Sunstein's limited reading posits that without the Opinions Clause, Congress could have prevented the department heads from providing opinions to the President. ${ }^{374}$ Lessig and Sunstein rely upon the Philadelphia Convention's rejection of a presidential power to demand opinions from the Chief Justice. All agree, they contend, that in the absence of constitutional authority to demand opinions from the Chief Justice, the President would lack such power. Analogously, if the President lacked the explicit power to demand written opinions from department heads, he would not have implicit constitutional authority to do so. ${ }^{375}$

While endorsing neither the limited nor the radical interpretation, Lessig and Sunstein entirely reject the notion that the founding generation viewed the Clause as redundant. Building upon Hart's work, they have proffered two elegant, plausible, and nonsuperfluous explications of the Clause. Given their assumption of nonredundancy and the pieces before them, they supply two possible resolutions to a puzzling dilemma.

Yet once one realizes that Lessig and Sunstein are missing crucial pieces of the department puzzle, both of their interpretations of the Clause collapse. ${ }^{376}$ The history of the Clause reveals that it was meant to assuage those who felt that the President would be lacking advice about how to exercise his constitutional powers.

\section{The Flaws of the Radical Reading}

The use of the words "Heads of Departments" in one Clause of the Constitution and "principal officers of the executive departments" in another

373. Lessıg \& Sunstein, supra note 1, at 36.

374. Id. at 34 .

375. Id. at 33 .

376. To their credit, Lessig and Sunstein admit that the differences in phrasing might not be probatuve. At the same time, they assert that a unitarian cannot satisfactonly account for the vanation. See $t d$. at 35 . We aim here to explain the differences. 
is entirely meaningless. A review of the pre-ratification statements of the Framers and ratifiers reveals that no one understood these differences as having any significance. Rather, both phrases refer to those who would be given statutory authority to help the President administer federal law, be it law concerning finances, the post office, or other federal matters.

The Opinions Clause was originally part of a plan to provide a Council of State for the President to assist him "in conducting the Public affairs."377 Introduced by Gouverneur Morris and Charles Pinckney on August 20, 1787, the Council proposal stated that the President could demand written opinions "of any one or more of the members" of the Council, which included the Supreme Court's Chief Justice and the Secretaries for Domestic Affairs, Commerce and Finance, Foreign Affairs, War, Marine, and State. He could also "submit any matter to the discussion of the Council of State."378 The plan placed responsibility squarely on the President, as he was not bound to accept their advice. On August 22, the Clause emerged from the Committee of Detail with a few alterations. ${ }^{379}$ Not only was the body renamed the "Privy Council," but the Committee had also added the Senate President and House Speaker to the Council. Moreover, the Clause no longer referred to Secretaries but instead referred to "the principal Officer in the respective departments of foreign affairs, domestic-affairs, War, Marine, and Finance, as such departments of office shall from time to time be established." 380

This version was subsequently sent to a Committee of Eleven (members), ${ }^{381}$ which, without explanation, shelved the idea of a Privy Council and instead returned the Opinions Clause to the full Convention. ${ }^{382}$ When George Mason resubmitted a proposal for a presidential council, Gouverneur Morris, the author of the original plan, explained that the Committee had rejected the Council because some believed that it would serve to shield the President from responsibility for the actions he might take. ${ }^{383}$ The Convention rejected the Council because it wanted to leave no room for doubt: The President was accountable for decisions. ${ }^{384}$

Far from signaling a dichotomy between principal officers of executive departments and department heads, the Committee of Eleven probably wanted to make clear that the President's Opinions Clause power only extended to institutions engaged in the execution of federal law, i.e., executive departments and officers. Recall that the Committee had received a proposal to grant the

377. 2 FEDERAL CONVENTION, supra note 134 , at 342 .

378. Id.

379. See 2 id. at 367.

380. Id.

381. Id.

382. 2 id. at 495 .

383. See 2 id. at 542; see also 1 id. at 97 (Wilson commenting on council's ability to "cover" rather than prevent malfeasance).

384. See Prakash, supra note 6, at 1006-07. 
President the authority to demand opinions from the Chief Justice, the House Speaker, and the Senate President. The alteration made clear that the President no longer enjoyed this authority. He could only ask for opinions from executive departments-shorthand for the previous long list of departments that had included "Finance," "domestic-affairs," and other departments that Congress might create. ${ }^{385}$ Since all these departments were "executive," i.e., they would be under the President's control, the term "executive departments" could be used instead of listing each department separately. ${ }^{386}$

The discussion of the Privy Council at Philadelphia reveals that the same individuals (persons charged with administration of departments such as Finance, War, Foreign Affairs, etc.) were referred to as both "secretaries" and "principal officers." Are we to believe that the Committee of Detail's alteration of the title of these positions from secretaries to principal officers had any significance? The radical Lessig/Sunstein thesis suggests so. Yet the change appears to be meaningless.

Throughout the Philadelphia Convention, the delegates employed different terms to describe heads of departments. Even prior to the Morris-Pinckney proposal, Pinckney thought there ought to be a council to help the President exercise a veto. He favored "joining the heads of the principal departments[:] the Secretary at War, of foreign affairs" and others in this council. ${ }^{387}$ Hamilton's draft constitution would have granted the President the sole appointment authority with respect to "heads or chief officers of the departments of Finance, War and Foreign Affairs. ${ }^{388}$ Gouverneur Morris thought the President ought to appoint "ministerial officers for the administration of public affairs." ${ }^{389}$ These "great officers of State; a minister of finance, of war, of foreign affairs \&c." would exercise their functions in subordination to the President. ${ }^{390}$ John Rutledge noted that the President could advise "with the officers of State, as of war, finance, \&c. and avail himself of their information and opinions." ${ }^{391}$ Oliver Ellsworth's Privy Council proposal stated that "Ministers" of Finance, War, Foreign Affairs, etc. would assist the President. ${ }^{392}$ Delegates employed different titles for those who would be statutorily charged with administration of the departments, but they referred to the same positions. ${ }^{393}$

385. 2 Federal CONVENTION, supra note 134, al 367.

386. The phrase also left no doubt that the President could seek opınıons not only from departments on the list, but from any executive departments that Congress might creale.

387. 1 Federal CONVENTION, supra note 134. al 139 (emphasis added).

388. 1 id. at 292 (emphasis added).

389. 2 id. at 52 (emphasis added).

390. 2 id. at 53 (emphasis added). Morris later referred to these same individuals as "Secretantes." See 2 id. at $342-43$.

391. 2 id. at 80 (emphasis added).

392. 2 id. at 329 (emphasis added).

393. The casual interchangeable use of the terms secretary, department heads, principal officers, and ministers continued after the Convention, with no one drawing the principal officer/deparment head 
The history of the Inferior Officers Appointments Clause, which contains the "Heads of Departments" provision, advances the notion that the phrase was not meant to distinguish department heads from principal officers. The Clause appeared to have been proposed as a means of relieving Congress and the President of the duty of nominating and confirming every officer of the federal government. ${ }^{394}$ Gouverneur Morris, the floor leader of the unitary Executive forces at the Convention, proposed the amendment the day before the last day of the Convention. ${ }^{395}$ Madison wondered if the proposal went far enough, as he thought "Superior Officers below Heads of Departments" ought to be able to appoint to lower offices. ${ }^{396}$ On a vote of five in favor, five opposed, and one state divided, the Convention rejected the Morris motion. Immediately after its initial rejection, the motion was put to a vote for a second time, since "some such provision [was] too necessary, to be omitted." 397 On the second vote, it was adopted unanimously.

This debate suggests two things. First, the Convention never focused on use of the term "Heads of Departments." Throughout the Convention, individual participants had used any number of terms in discussing what we today call Secretaries. In this particular proposal, they happened to be labeled "Heads of Departments." Moreover, given that Gouverneur Morris proposed the Clause, we should be extremely reluctant to read it as intimating that there were nonexecutive departments. After all, it was Morris who observed that "officers of state" such as the ministers of Finance and War would "exercise their functions in subordination to the Executive." 398 As a strong

distinction. James Iredell, future Supreme Court Justice, wrote that the President would enjoy the aid "of the principal officers of the great departments," failing to distinguish between executive and nonexccutive departments. JAMES IREDELL. ANSWERS TO GEORGE MASON'S OBJECTIONS TO THE NEW CONSTITUTION (1788), reprinted in PAMPHLETS, supra note 331, at 348 (emphasis added). Ellsworth, writing as The Landholder, pointed to the Opinions Clause to assuage the fears of those who felt that the President would be bereft of advice. "[I]f any information is wanted, the heads of the departments who are always at hand can best give it." 3 DOCUMENTARY HISTORY OF THE RATIFICATION, supra note 225, at 489 (emphasis added). Hamilton discussed "the principal departments of the administration" and referted to "a secretary at war, a secretary for foreign affairs, a secretary for domestic affairs, [and] a board of treasury." Thie FEDERALIST No. 84, at 518 (Alexander Hamilton) (Clinton Rossiter ed., 1961) (emphasis added). Federal Farmer, when speaking of the Inferior Officers Appointments Clause, claimed that the "principal officers in the departments . . . will . . . be best informed as to proper persons to fill inferior offices in them." 2 ANTI-FEDERALIST, supra note 277, at 308 (emphasis added). At the same time, he also labeled those individuals "heads of departments." Id. (emphasis added).

394. Without the Clause, the President would have to nominate and the Senate confirm all executive and judicial officers of the federal government. The Clause establishes a commonsense method of circumventing the default rule of Presidential nomination/Senate confirmation, thus saving time and resources.

395. 2 FEDERAL CONVENTION, supra note 134, at 627.

396. Id.

397. 2 id. at $627-28$.

398. $2 \mathrm{id}$ at 54 
unitarian, ${ }^{399}$ it is exceedingly unlikely that Morris promoted a Clause that presupposed an executive/nonexecutive department dichotomy. ${ }^{ \pm 0}$

Prior to the Constitution's adoption, then, no one viewed the differences in language as at all meaningful. The radical reading of the Clause-namely that the President only has the authority to ask for opinions of the principal officers in executive departments, and not for those of heads of "administrative" departments-has no pre-ratification support. $\$ 01$

\section{The Defects of the Less Radical Reading}

Recall that Lessig and Sunstein argue that without the explicit constitutional authority to demand written opinions of department heads, the President would lack such power. Philadelphia delegates, however, disagreed. Speaking well before the adoption of the Opinions Clause or even the debate regarding the Council of State, Gouverneur Morris, the Council proposal's coauthor, noted that " $[t]$ here must be certain great officers of State; a minister of finance, of war, of foreign affairs. [Morris] presumes [these officers] will exercise their functions in subordination to the Executive. . . Without these ministers the Executive can do nothing of consequence." $\$ 02$ Obviously, the President could call upon these officers of State to provide advice, since they would "exercise their functions in subordination to the Executive." Similarly, Rutledge, objecting to a council of revision that would exercise a veto power, thought the President should have the sole power to veto, and, if necessary, he "could advise with the officers of State, as of war, finance [etc.] and avail himself of their information and opinions."

399. See generally. Prakash, supra note 6, at 996 n.32.

400. As this history shows. the Clause is an unlikely candidate for Professor Froomkan's interpretalion. See supra note 202. Just as Gouverneur Morris did not intend to create an executive/administratuve dichotomy, he cerainly did not intend to suggest that the heads of depamments would somehow be independent of the President. His consistent position was that they were subordinate to the Chicf Magistrate. See Prakash, supra note 6, at 1008. The brief and lasi-minute nature of the debate on the Clause indicates that no one focused on the wrinkle that Froomkin highlights. As with the Constitutson's discussion of unspecified duties and powers of department heads, see supra note 204. We think the Clause represents another minor blemish in an otherwise consistent document that establishes a unitary Executsve.

401. During the ratification debate, people understood that the Continental Congress' Secretanes of War and Foreign Affairs, along with the Superintendent of Finance. were all executive officers administering federal law. A Citizen of New Haven noted that the new federal government would not need new "officers in the executive deparment." 15 DOCUMENTARY HISTORY OF THE RATIFICATION, supra note 225 , at 281 . He implied that the Secretaries, the Superiniendent, and all their assistants were executuve officers in the Continental Congress' executive department. Hamilton made the exact same argument:

It is evident that the principal departments of the administration under [the Articles]. are the same which will be required under the new. There are now a secrelary at war. a secrelary for foreign affairs, a secretary for domestic affairs, a board of treasury consistung of three persons, a treasurer, assistants, clerks. \&c.

THE FeDERALIST No. 84. at 518 (Clinton Rossiter ed., 1961). What he did not say at this point is that these individuals, as part of the "administration," are subordinate to the President who controls the Administration. See THE FEDERAL.15T No. 72, at 435-36 (Alexander Hamilton) (Clinton Rossiter ed., 1961). 402. 2 FEDERAL CONVENTION, supra note 134, at 53-54.

403. 2 id. at 80. See generally 2 id. at 73-82 (debate over council of revision). 
Why did the Framers assume the President would have authority to demand the advice of department heads? Because they presupposed that these department heads were constitutionally subordinate to the President. Hamilton, Morris, and Pinckney all affirmed that the department heads were constitutionally subordinate to the President. In The Federalist No. 72, Hamilton noted that the "actual conduct of foreign negotiations, the preparatory plans of finance, the . . . disbursement of public monies" would be committed to the "immediate management" of those who "ought to be considered . . . the assistants or deputies of the Chief Magistrate" and be "subject to his superintendence." ${ }^{, 04}$ Similarly, as noted above, Gouverneur Morris declared that the great officers of State, such as the "minister of finance," would exercise their functions in subordination to the Executive. ${ }^{405}$ Pinckney thought that if the President decided that an officer was failing in his duties, he could correct the error and punish the officer. ${ }^{406}$ Under any of these understandings of the President's constitutional authority, the President obviously could demand advice from department heads.

As for Lessig and Sunstein's argument by implication based on the rejection of a presidential power to demand advice from the Chief Justice of the Supreme Court, ${ }^{47}$ there is an easy rejoinder. Absent a constitutional provision that explicitly grants the President the authority to ask for opinions of the Chief Justice, he obviously lacks such authority. This is so because the Supreme Court lies outside the executive branch; it and the rest of the judiciary are to be independent of and separate from the other two branches. In contrast, department heads are part of the executive branch because they help the President execute federal law. Hence, the fact that the Convention rejected presidential authority to demand advice from the Chief Justice (or for that matter the Speaker of the House and President of the Senate) has no bearing on the question of whether the Framers would have thought that the President had an implicit power to ask for advice from department heads in the absence of the Opinions Clause.

Philadelphia delegates had repeatedly rejected associating the Executive with the judiciary on a council of revision that would exercise veto authority. Giving judges influence on legislation that would become law would be inappropriate because they might be called upon to "expound" on these laws at a latter date. ${ }^{408}$ Joining judges with the President would also enable either

404. THE FEDERALIST No. 72, at 435-36 (Alexander Hamilton) (Clinton Rossiter ed., 1961). Note that Hamilton includes budgeting and disbursement of funds as functions that the President will control, even though Lessig and Sunstein assert that such administrative authority can be apportioned by Congress. See Lessig \& Sunstein, supra note 1 , at $46,71$.

405. 2 FEDERAL CONVENTION, supra note 134 , at 53-54.

406. 3 id. at 111 .

407. See Lessig \& Sunstein, supra note 1, at 33-35.

408. See 1 FEDERAL CONVENTION, supra note 134, at 98 (King arguing that "[j]udges ought to be able to expound the law as it should come before them, free from the bias of having participated in its 
to influence the other improperly. ${ }^{409}$ Finally, granting judges a veto would embroil them in policy disputes, which was inappropriate for judges. 10

If these principles were accepted, why was the Chief Justice initially included in the President's Council of State? Gouverneur Morris, the Council proposal's coauthor, always supported connecting the judiciary with the Executive in the exercise of the veto power. ${ }^{+11}$ Not having changed his mind, he once again suggested that a judge and the President work together, this time on the Council of State. When this proposal went to the Committee of Eleven, the Committee withdrew the President's ability to demand advice from the Chief Justice, the House Speaker, and the President of the Senate. Now the President could only seek advice from executive officers, not judicial or legislative ones. The principles that led the Convention to repudiate associating judges and the President in the exercise of the veto probably prompted the Committee of Eleven to reject placing the Chief Justice on the Council of State. Combining the Chief Executive with a member of the judiciary had already been rejected numerous times. Rather than waiting for the Convention to reject this relationship once again, the Committee wisely decided to amend the plan itself, permitting the President to demand opinions from executive officers only.

\section{The True Meaning of the Clause}

But if the above discussion regarding joining the Chief Executive with the Chief Justice is correct and the Framers assumed that the President would already have the power to demand the opinions of department heads, why was the Clause included in the Constitution at all? Recall that Gouverneur Morris of the Committee of Eleven supposed that the President would be able to hide behind the Council of State and escape responsibility for decisions. ${ }^{+12}$ At the same time, acting out of an abundance of caution, the Committee of Eleven probably wished to forestall any suggestion that the President would be left without advice on how he ought to exercise his various authorities. Hence, it included the Clause. The President could get advice-no one could distort the

formation"); 2 id. at 75 (Caleb Strong arguing same); 2 id. at 79 (Nathanial Gorham argung same): 2 ud. at 80 (John Rutledge arguing same); THE FEDERALIST No. 73, at $446-47$ (Alexander Hamition) (Clinton Rossiter ed., 1961) (explaining why President not associated with judiciary in exeresse of veto).

409. 1 FEDERAL CONVENTION, supra note 134, at 139 (Elbridge Gerty claiming that Executuve would be "seduced by the sophistry of the Judges"); THE FEDERALIST No. 73. al 446 (Alexander Hamiton) (Clinton Rossiter ed., 1961) (observing that judges who became 100 "often associated with the executive ... might be induced to embark too far in the political views of that magistrate").

410. Elbridge Gerry opposed the Virginia Plan's association of the President and judges on a councal of revision. "It [is] quite foreign from the nature of [the] office to make them judges of the policy of public measures." I FEDERAL. CONVENTION, supra note 134, at 97-98; see also 2 ud. al 74-75 (arguing that inclusion of judges on council of revision would improperly make them both "Statesmen" and "Legislators").

411. 2 id. at 75 .

412. See 1 id. at $97 ; 2$ id. at 542 . 
Constitution and assert otherwise. ${ }^{413}$ In this sense, as noted earlier, ${ }^{414}$ the Clause is not redundant-it serves a purpose, namely making explicit what is already implicit in the establishment of a Chief Executive, and thus leaving no doubt about the existence of such authority.

If, however, Lessig and Sunstein insist upon an interpretation of the Clause that goes beyond asserting that it was included out of an abundance of caution, we provide it: The Clause limits presidential authority by implicitly forbidding the President from demanding opinions on subjects not related to the statutory duties of an officer. The Clause makes clear that the President may only request opinions in writing from officers "on any subject relating to the Duties of their respective Offices." ${ }^{415}$ In sharp contrast, the King of England could ask his Privy Councillors for generic advice "according to the best of [their] cunning and discretion," since they were to advise "for the king's honour and good of the public, without partiality through affection, love, need, doubt, or dread." 16 Thus, the Clause might constitute a limitation on what might otherwise be a broader executive power to request opinions pursuant to English practice.

Ultimately, both of Lessig and Sunstein's interpretations of the Opinions Clause are problematic. The radical reading exalts meaningless differences in constitutional text and is contradicted by the numerous statements of the founding generation. ${ }^{417}$ The less radical interpretation contradicts the statements of the Framers that department heads would be subordinate to the President. The Clause was probably included out of an abundance of caution to make clear that the President would not lack advice; if one insists on a non"redundant" reading, however, there is an interpretation more consistent with constitutional text, structure, and history. Perhaps the Clause restricts the President's power to demand opinions; he may only demand opinions on subjects relating to the department heads' statutory duties. In either case, the terms "department heads," "principal officers," "secretaries," and "ministers" are all interchangeable; all are constitutionally subordinate to the President.

413. Nonetheless, George Mason vociferously criticized the lack of a proper council that could advise the President. THE OBJections of the HON. GEORGE MASON to THE PROPOSED FEDERAL CONSTITUTION (1787), reprinted in PAMPHLETS, supra note 331, at 330; see also The Address and Reasons of the Dissent of the Minority of the Convention of Pennsylvania to Their Constituents (1787), reprinted in 3 ANT1FEDERALIST, supra note 277, at 146, 162 (advocating inclusion of independent advisory council to President, who could not make appointments or act without approval of majority of quorum of council); Letter from Richard Henry Lee to Governor Edmund Randolph (Oct. 16, 1787), in 5 ANTT-FEDERALIST, supra note 277, at 112,117 (urging addition of council of revision to advise President on appointments).

414. See supra part III.C.

415. U.S. CONST. art. II, § 2, cl. 1.

416. 1 William BLACKSTONE, COMMENTARIES *223.

417. See supra part III.C. 


\section{E. A Review of the Pre-Ratification Original Understanding of the Constitution}

Our review of the pre-ratification understanding affirms the textual arguments made in Part III. When members of the founding generation discussed executive power, they were considering the authority to execute the law. Second, their references to "administration" always mentioned the President's central administrative role; indeed. they used the terms "administration of law" and "execution of law" interchangeably. The Take Care Clause either makes the President's authority to execute laws even more apparent, or alternatively, it may limit his authority, by possibly preventing him from completely suspending laws. The Necessary and Proper Clause does not grant Congress the authority to impinge upon a presidential power or to weaken a presidential duty; it surely does not license Congress to wrest the power to administer federal law away from the President. The Opinions Clause presumes a superior-subordinate relationship between President and department heads; it may also limit the President by restricting the advice he may demand to opinions related to the department heads' statutory duties. Finally, the interchangeable use of numerous terms for officers we today call Secretaries indicates that "principal officers in the Executive Departments" and "Heads of Departments" are one and the same. Under the Constitution, all those helping to execute laws (be they department heads or file clerks) are executive officers, assisting the President's execution of the executive power.

The next Part analyzes post-ratification understandings of the President's administrative position. While examining the same statutes that Lessig and Sunstein inspect, this Part expands the scope of analysis by also scrutinizing administrative practice in the Washington Administration and congressional and presidential statements regarding the President's role in administration.

\section{Post-Ratification Understandings of the President's ADMINISTRATIVE ROLE}

As we cautioned earlier, we ought not conflate the first Congresses (or Presidents) with the Constitution's Framers and ratifiers, thus confusing the pre-ratification original understanding with post-ratification views. ${ }^{\text {s8 }}$ But

418. See supra part I.C. A footnote to the contrary notwithstanding. see Lessig \& Sunstein. supra note 1, at $13 \mathrm{n.47}$, the Lessig and Sunstein originalist methodology comes strikingly close to a post hoc rationalization of congressional action. They have assiduously plotted congressional data points (in the form of statutes) and then attempted to find a textual theory that makes sense of that data. Unfortunately, as we saw above, they are missing quite a few extremely relevant data points. See supra pars IV. V. And as we shall soon discover, Lessig and Sunstein do not plot their data points accurately. in that they misconstnue the congressional intent behind certain statutes. Though Congress did not expressly sanction presidentual superintendence of certain institutions and officers. there is no evidence to suggest ihat Congress meant to deny presidential control over those agencies. 
even if we assume that Congress faithfully hewed to the Constitution, Lessig and Sunstein's analysis of post-ratification history suffers other serious flaws.

By focusing on statutes and largely ignoring the debates that led up to their enactment, Lessig and Sunstein completely miss the rancorous exchanges concerning the President's administrative role. ${ }^{419}$ Congress was divided, and some members were confused, about the President's constitutional position. Some members understood that the President could superintend the administration of federal law and that officers statutorily charged with execution would be subject to his direction. Others, however, rejected the notion of presidential superintendence of federal execution.

Once one fully appreciates congressional division and confusion, it becomes much more difficult to draw definitive conclusions regarding the views of the first several Congresses. Indeed, once one realizes that not one of the statutes cited by Lessig and Sunstein explicitly declares that the President may not superintend execution of the various departments, agencies, and officers created, one appreciates that their claims about the import of these statutes are based on arguments by inference. Lessig and Sunstein construe congressional silence regarding presidential superintendence as a rejection of any such assertion. Looking behind the statutes to their legislative history, however, discloses that members understood that the various departments they created would be subject to presidential control, notwithstanding the lack of explicit statutory authority.

Most important, this Part fills a gap in Lessig and Sunstein's account of the early post-ratification years. Because they focus on post-ratification history to illuminate constitutional text, they presumably would welcome an investigation of Washington's views. Unlike Congress, Washington possessed a lucid understanding: The Constitution granted him the power to execute federal law. Any departments and officers would be subordinate to him. ${ }^{420}$

We will consider Washington's understanding first, moving to congressional debate about the status of executive officers and ending with a discussion of specific statutes. As we shall see, no post-ratification evidence fundamentally calls into question the original understanding that the President would superintend the execution of all federal laws. ${ }^{421}$

419. Their discussion of the congressional debate is largely limited to one page. See Lessig \& Sunstein, supra note 1 , at $25-26$. The rest of their conclusions regarding congressional intent are inferences drawn from interstatutory comparisons.

420. Since others have already examined issues surrounding administration of law during the Washington years, we draw heavily from their excellent work. In particular, we rely upon the historical research of James Hart, Forrest McDonald, Glenn Phelps, and Leonard White. See HART, supra note 372; MCDONALD, AMERICAN PRESIDENCY, supra note 139; MCDONALD, PRESIDENCY OF GEORGE WASHINGTON, supra note 368; GLENN A. PHELPS, GEORGE WASHINGTON AND AMERICAN CONSTITUTIONALISM (1993); WHITE, supra note 236 .

421. In examining historical practices for the purpose of construing constitutional text, we recognize that we run the risk of perceiving clarity where there is none. Glenn Phelps has noted that Washington set a number of precedents, not all of which were "natural" or inevitable at the time. See PHELPS, supra note 


\section{A. Washington's Administrative Understanding}

\section{The Chief Executive and Other Federal Executives}

The very first executive transition, that is, the transition from congressional control of execution to the constitutionally mandated presidential control of execution, reflected the continuing influence of the Articles of Confederation. Pending creation of new departments and offices under the new Constitution, President Washington asked many officers to remain. ${ }^{22}$

At the same time, though there may not have been an immediate and dramatic upheaval in personnel, there were rather striking alterations in beliefs and practices. Less than a month after his inauguration, before he established new departments, Washington expressed his view of the President's relationship to departmental officers. In a letter to Frenchman Count de Moustier, Washington observed that "[t]he impossibility that one man should be able to perform all the great business of the State, I take to have been the reason for instituting the great Departments, and appointing officers therein, to assist the supreme Magistrate in discharging the duties of his trust." 23 Undoubtedly, Washington was expressing his understanding that since the Supreme Magistrate was the only officer constitutionally charged with faithfully executing federal law, all officers and departments created by statute to execute federal law existed to assist the President. ${ }^{425}$

Washington did not wait long to assert his authority as Supreme Magistrate. A mere month and a half after his inauguration, the President wrote to the Board of Treasury and the Acting Secretaries of War and Foreign Affairs, asking them to provide him "an acquaintance with the real situation of the several great Departments, at the period of my acceding to the administration of the general Government." Accordingly, he demanded a "full, precise, and distinct general idea of the affairs of the United States, so far as they are comprehended in or connected with" a particular department. ${ }^{23}$

420, at 123; see also Monaghan, supra note 6, at 33 (notung danger of reading sharp distunctions into history). We agree that Washington undoubtedly established precedents that have little to do with our original Constitution (his decision not to seek a third term comes to mind). At the same ume, we do believe that some of Washington's actions stemmed from his understanding of his constututional powers and obligations, in particular, his consolidation of administrative control in his hands.

422. Washington not only asked minor officers like the wardens of the Pon of New York to stay on. see HART, supra note 372, at 138, he also asked senior executive officials, such as John Jay (Secretary of Foreign Affairs) and Henry Knox (Secretary of War), to continue in office. See id. at 134.

423. 30 WRITINGS OF GeORGE Washington 334 (John C. Filzpatrick ed.. 1939).

424. As we argued earlier, a magistrate is one charged with exceuting laws. See supra notes 328-29.

425. 30 WRITINGS OF GEORGE WASHINGTON, supra nole 423. at 344. Washington sent a stmilar letier to the Postmaster General. 30 id. at 344 n.30. Though Lessig and Sunstein clam that the Constitution may distinguish between principal officers and heads of departments, see Lessig \& Sunstein, supra note 1, at 37-38, Washington made no such distinction. He demanded opinions of all the top administratuve officers of the important deparments, even though the deparments were holdovers from the defunct Articles of Confederation era. This was quite natural because they were all executive departments. 
Washington was acutely aware of the consequences of an impotent federal administration. Perhaps recalling the failure of administration under the Articles, he considered "the successful Administration of the general Government as an object of almost infinite consequence to the present and future happiness of the Citizens of the United States."426 To this end, Washington impressed upon the heads of departments the need for an energetic executive branch, possibly remembering that one of the reasons for the Constitution's establishment of a unitary Executive was the belief that it would contribute to a more prompt and vigorous administration. He admonished the department heads to "deliberate maturely, but to execute promptly and vigorously. ... Without an adherence to these rules, business never will be well done, or done in an easy manner . . . ."427

Leonard White, perhaps the most thorough chronicler of the Washington Administration, maintained that "[a]11 major decisions in matters of administration ... were made by the President." 428 Regardless of how departmental decisions were made, however, White asserts that Washington accepted full responsibility for all departmental actions; after all, as White notes, they were nothing but "dependent agencies of the Chief Executive."429 Likewise, Glenn Phelps, who exhaustively canvasses Washington's views on constitutionalism, observes that "Washington's presidency reflected [a] concern for administrative centralization. There would be no divided responsibility or ambiguity as to who was the chief executive." 430

426. 30 WRITINGS OF GEORGE WASHINGTON, supra note 423, at 510.

427. $35 \mathrm{id}$. at 138 . Such presidential direction of the departments was not unusual; rather, Washington was intimately involved in departmental matters, exchanging frequent written and oral communications with department heads. WHITE, supra note 236, at 32. On occasion, he would have breakfast with Jefferson, Hamilton, and others. Other times, he proceeded to their offices to discuss matters with them. The contacts were frequent and administrative matters were discussed. Id. Washington's discussions with the department heads were not limited to the department heads' statutory responsibilities as the Opinions Clause states. Instead, Washington consulted his Cabinet on all sorts of matters. See PHELPS, supra note 420, at 162. Washington's discussions and practices support the proposition that the Opinions Clause is in fact redundant.

428. WHITE, supra note 236, at 27. Our first President was not involved only in vital administrative affairs, however, as he intimately involved himself in seemingly trivial matters as well. White insists that "no collector of customs, captain of a cutter, keeper of a lighthouse, or surveyor of revenue was appointed except after special consideration by the President." Id. at 106. In a letter to Treasury Secretary Hamilton, Washington outlined the organization of the Internal Revenue Service. 31 WRITINGS OF GeOROB WASHINGTON, supra note 423, at 238-39. Writing to Secretary of War Knox, an irritated Washington inquired about the activities of a Mr. Rosencrantz, who had attended some Indian Councils: "No person should presume to speak to the Indians on business of a public nature except those who derive their Authority and receive their instructions from the War Office for that purpose." $32 \mathrm{id}$. at 116-17.

429. WHITE, supra note 236, at 27. All the department heads, including Treasury Secretary Hamilton, understood that they worked for the President. Id.; see also MCDONALD, PRESIDENCY OF GEOROE WASHINGTON, supra note 368, at 40; PHELPS, supra note 420, at 184. Even before Washington was chosen as President, Hamilton recognized that Washington would head the Administration. Washington's presidency would "insure a wise choice of men to administer the government and a good administration. A good administration will conciliate the confidence and affection of the people." 4 DOCUMENTARY HISTORY OF THE RATIFICATION, supra note 225, at 290.

430. PHELPS, supra note 420 , at 145 . We ought not be surprised by Washington's views regarding the Chief Executive. During the Confederation's impotent administration, Washington had argued for strong. 


\section{The Federal Chief Executive and the State Executives}

Lessig and Sunstein observe that many Framers and ratifiers recognized that state officers would often be called upon to execute federal law. ${ }^{431}$ Lessig and Sunstein promptly conclude that these state executives could not possibly have been thought to be under the federal Executive's control. ${ }^{\mathbf{3 2}}$ Clearly, "[t]he President had no power to remove state executives who executed federal law in a way inconsistent with the President's vicw about how such laws should be executed .... [E]qually obvious, the President had no power to recall the authority [granted by statute to] state executives to execute federal law." 433

Yet neither conclusion is obvious at all. They only seem so if one assumes the proposition one wishes to establish. Lessig and Sunstein hope to prove that the President has no constitutional authority to superintend the execution of all federal law; assuming he does not, he obviously cannot direct state officers enforcing federal law. Nor can he remove them.

On the other hand, if one accepts the proposition that the President is the only individual constitutionally granted the executive power and that this authority includes the ability to direct the execution of federal law, then it would be "equally obvious" that the President could direct state officers in their execution of federal law or extract their federal authority from them. The Framers wished to construct a unitary Executive since they felt it was conducive to energy, dispatch, and responsibility. ${ }^{434}$ Insofar as officers exercise that authority independent of the Supreme Magistrate, there is no presidential accountability and the design of the founding generation is thwarted. The President can direct state officers in the exercise of federal executive authority because when these state officers execute federal law, they act on behalf of the President, the federal Chief Executive. Moreover, since the President may remove purely federal officers ${ }^{435}$ who fail to carry out their duties, the President may also "remove" state officers who fail to perform their duties adequately. That is to say, the President can refuse to allow a state officer to exercise the federal executive power, just as he can refuse to permit a purely federal officer to do so. There is no difference. ${ }^{.36}$

independent executives. See id. at 56,59, 142. He was also known to be an influential, albeit largely silent, Philadelphia delegate in favor of a strong Executive. See id. at 103.

431. Lessig \& Sunstein, supra note 1. at 31. If one accepts the argument that prosecutors are but specialized executive officers, see infra part VI.C.3. then Lessig and Sunstern's treatment of state prosecutors, Lessig \& Sunstein. supra note 1. at 19. and state executives can be discussed together. For now, please accept that proposition.

432. Lessig \& Sunstein, supra note 1, at 19, 31, 69.

433. Id. at 31 .

434. See Prakash, supra note 6, at 998-99.

435. See supra par III.F.

436. To some, this may seem highly intrusive to a state's internal executive officer pool. Indeed, Lessig and Sunstein cite Mr. Prakash's article, Field Office Federalism, for the proposition that the Framers 
We ought not be surprised that when called into federal service, state executives serve under the President's control. ${ }^{437}$ This is really no different from when state militias (state executives by any other name) are called into federal service to assist the President in executing the laws, crushing rebellions, etc. ${ }^{438}$ When state courts hear federal claims, we quite naturally expect that they will follow the lead of the Supreme Court in the interpretation of federal law. ${ }^{439}$ Similarly, state executives (be they prosecutors, police officers, or tax collectors) must accept instructions from the President when enforcing federal laws. The President is to state executives as the Supreme Court is to state courts. ${ }^{440}$

But the above is not mere speculation. Once again, Washington put these understandings into practice. When Citizen Genet, the French ambassador to the United States, sought American assistance for France's war with Britain, Washington commanded the assistance of Governor Thomas Mifflin of Pennsylvania in enforcing the Neutrality Proclamation. ${ }^{441}$ Despite the fact

\footnotetext{
"imagined that the execution of some federal law could be vested in officers subject neither to the removal power nor the directory power of the President." Lessig \& Sunstein, supra note 1, at 69 (citing Prakash, supra note 226, at 1990-2007).

Lessig and Sunstein have misconstrued Mr. Prakash's argument. Mr. Prakash merely noted that though the federal government could make use of state executive officers, it could not regulate the states' hiring practices. Congress could not, for instance, tell the states whom they had to hire as statc exccutives, even though Congress might use those executives to help administer federal law. If the federal government wishes to commandeer state executives, it must take them as is. See Prakash, supra note 226, at 2000. As Mr. Prakash noted elsewhere in the same section of that article, the state officers commandecred into federal service would be subject to presidential control. Id. at 1990, 1995.

437. If Lessig and Sunstein wish to believe that it is unconstitutional for the federal Executive to direct state executives in the administration of federal law, potential inconsistencies in their own theory of administrative versus executive laws emerge. See Lessig \& Sunstein, supra note 1, at 45-46. They insist that the President must superintend the administration of so-called executive laws, i.e., those laws that carry into execution one of the President's Article II prerogatives.

Suppose that Congress directs state executives to help run federal military installations. Lessig and Sunstein acknowledge that the President must control the military and presumably the civilians that help administer the military. But they also assert that the President may not direct state executives charged with execution of federal law. These claims collide in this hypothetical.

438. See U.S. CONST. ant. $1, \S 8, \mathrm{cl} .15 ;$ id. art. II, $\S 2$, cl. I. Indeed, Washington used state militias to help suppress frontier Indians. See PHELPS, supra note 420, at 132-33.

439. The State Judges Clause requires state courts to enforce federal law (to "be bound thereby"). U.S. CONST. art. VI, cl. 2. Implicit in that requirement is that state courts will be bound by federal court interpretations of federal law, whether the law is the Constitution, treaty, or plain statute.

440. Moreover, though the Supreme Court has no constitutional authority to preclude a state court from hearing a federal case, notwithstanding that court's proven incompetence, the President may prohibit state officers from enforcing federal law. Article II, with its investiture of the executive power in the President, contemplates a much more hierarchical, administratively centralized branch than the judiciary. See Calabresi \& Rhodes, supra note 6, at 1203-04. The relationship between the Supreme Court (and other federal courts) and state courts was meant to be established by statute; both could hear federal cases. See Prakash, supra note 226, at 2007-20. In contrast, the Constitution empowers the President alone to administer federal law. Congress determines who assists the President, be they state and/or federal executives; but once an individual becomes involved in the administration of federal law, the Constitution decrees that she be subject to presidential direction. Though the President cannot remove a state executive (and thus interfere with a state's executive officer pool), he may "remove" that state officer's federal authority, notwithstanding congressional "deputization" of that officer.

441. PHELPS, supra note 420, at 129. Washington needed information regarding a ship docked in the Philadelphia port. French partisans had captured this former British merchant ship with the intent of
} 
that Governor Mifflin was an old political foe of President Washington, Mifflin "never once questioned Washington's authority to subordinate a state governor on a matter of this sort." ${ }^{\text {,42 }}$

Asserting authority over governors was not limited to the foreign affairs context, however. Washington also called upon state courts and executives to help enforce a federal tax on "spirituous liquors." defied the tax as it fell disproportionately on a main source of their income. Rather than calling in the army to deal with the rebellion, Washington called upon state officials to help him deal with the rebels. Citing his duty "'to take care that the laws be faithfully executed," Washington urged state officers to use their "weight and influence" to bring the rebels to justice." Based on his examination of the Citizen Genet Affair and the Whiskey Rebellion, Glenn Phelps asserts that where law enforcement was concerned, "Washington firmly believed that governors were constitutionally subordinate to the president."

Even this cursory review of the Washington Administration demonstrates that Lessig and Sunstein are mistaken when they insist that Washington presided over a "meek and timorous" institution." Contrary to their assertion that the "Tale of the Bank" marks the "first successful claim by an executive of a power" to execute all federal laws, ${ }^{47}$ Washington, from the very beginning of his administration, comprehended that he was constitutionally in charge of execution. ${ }^{448}$ Indeed, recognizing his preeminent

converting it into a warship.

442. Id. Forrest McDonald recounts other incidents stemming out of the Neutrality Proclamalion penod in which Washington enlisted the aid of governors. Governors were "requested to use their suborulnate officials and state militias" to enforce the federal "law" of neutralıty. MCDONALD. PREStDENCY OF GEORGE WASHINGTON, supra note 368 , at 127.

443. PHELPS, supra note 420 , at 131.

444. Id. at 132 (citations omitted). As a means of sapping the strength of the rebellion. Washington offered blanket pardons to those who would lay down their arms. See MCDONALD, AMERICAN PRESIDENCY. supra note 139, at 306 . Such pardons would seem to be in tension with the notion that the President may not "suspend" the laws or execution of them. When issuing a pardon, the President is essentually fauling to "take Care that the Laws be faithfully executed." U.S. CONST. ant. II. \$3. Maybe the way out of this dilemma is to note that when a President issues a blanket pardon pursuant to his pardon authonty. the President is on solid legal ground, as the Constitution (which is after all a law, see Easterbrook, supro note 162 , at 919) permits him to suspend application of a statute through the issuance of a blankel pardon.

445. PHELPS, supra note 420, at 132.

446. Lessig \& Sunstein, supra note I, at 83. Lessig and Sunstein cite nothing to support thesr assertion that the Washington Administration was "weak and timorous." Perhaps they confuse Washington's reluctance to comment on pending legislation, see id. at 13 n.42 (citing WHITE, supra note 236, at 55), with a general aversion to administration. Whatever Washington's views on the propriety of discussing legislation before Congress, his opinion on that matter has little to do with the President's role in the execution of laws enacted.

447. Id. at 78 .

448. Lessig and Sunstein claim that the Tale of the Bank is the starting point for the "mammoth transformation" in the nation's conception of the presidency. Id. at 81 . Nothing could be further from the truth. From the beginning. Framers, ratifiers, and ratification opponents understood that the President would superintend the execution of federal laws and that he would direct those officers who were to exceute federal law. If anything. President Adams' decentralized administrative philosophy marked a departure from the original understanding of vigorous, presidentially superintended administration. See MCDONALD. PRESIDENCY OF GEORGE WASHINGTON, supra note 368 . al 184. 
and powerful executive role, Washington referred to himself as the "Chief Magistrate." 449 To paraphrase Washington, could he execute all the laws himself, there would be no need for departments. But given the impossibility of such a task, department heads and the departments themselves existed to assist him in discharging his constitutional duties and in exercising his constitutional prerogatives. ${ }^{450}$

\section{B. A Conflicted Congress' Views Regarding Presidential Administration: Early Removal Debates}

While Washington had a coherent and compelling understanding of his administrative role, no single understanding of the Executive's role garnered the favor of a congressional majority. Congress began pondering the relationship between department heads and the President in its famous removal debates, the so-called "Decision of 1789." Some understood that the President would superintend the administration of federal law and that department heads were to be subordinate to him. Others, however, thought department heads (and other executive officers) ought to be independent. ${ }^{451}$ By implication, federal execution would be free from presidential control as well.

Representative William Smith of South Carolina, the chief proponent of the impeachment theory, supposed that since no means of removal beyond impeachment were mentioned in the Constitution, impeachment was the only method. Only a Senate trial could deprive a department head of his "property

449. PHELPS, supra note 420 , at 141.

450. Washington thus held an expansive notion of what constituted the executive power. McDonald claims that Washington understood "that exccutive authority was solely the president's, that the Senate had no share in it beyond that of approving or rejecting his appointments and treaties, and that department heads were responsible directly to him." MCDONALD, PRESIDENCY OF GEORGE WASHINGTON, supra note 368, at 39.

Lest anyone believe that we are according too much weight to Washington's views regarding administration, let us recall that we present these views only to fill the gap in Lessig and Sunstcin's account of the post-ratification original understanding. Further, it seems to us that if anyone's post-ratification vicws merit deference, Washington's do. Washington, always sensitive to the opinions of his countrymen, consistently strove to stay within the confines of the Constitution. Phelps notes that Washington even went so far as to withdraw the nomination of William Patterson to the Supreme Court when Washington learned that confirmation of Patterson would violate the Constitution's Emoluments Clause. See PHELPS, supra note 420, at 137-38. Phelps claims that the withdrawal was part of a principled strategy of strengthening the presidency by an "appropriate (and highly visible) deference to the Constitution." Id. at 138. Morcover, Washington was acutely aware that the precedents established in the beginning would influence posterity. Accordingly, he "'devoutly wished" that "these precedents may be fixed on true principles." Casper, supra note 246, at 225 (quoting 12 THE PAPERS OF JAMES MADISON 132 (C. Hobson \& R. Rutland eds., 1979)); see also PHELPS, supra note 420, at 122.

451. White labels those who thought department heads ought to be autonomous as "extreme Republicans," the more extreme of whom believed that even ambassadors were free to do whatever they pleased. WhITE, supra note 236, at 94; see also MCDONALD, PRESIDENCY OF GEORGE WASHINGTON, supra note 368 , at 95 (noting same). Federalists, on the other hand, insisted that the Constitution enabled the President to control executive officers, be they department heads or subordinate executive officials. WhITE, supra note 236 , at $89,91-94$. 
right" in his office. ${ }^{452}$ Smith must have realized that removal by impeachment alone would afford these department heads tremendous independence.

Proponents of the "President-and-Senate theory of removal" contemplated a somewhat more active presidential role. Representative Alexander White regarded the Senate as an executive body when it performed its constitutional functions of confirming officers and approving treaties. Every controversy concerning either subject had to be considered by the Senate. ${ }^{\$ 33}$ Hence, Senate "consent" was necessary not only for appointments, but for removal as well. Elbridge Gerry asserted that a Senate check on removal would encourage a stable magistracy. ${ }^{454}$ Like the impeachment theory, this theory implied independent department heads, and it was denounced on this ground. Madison noted that the theory would enable department heads to form alliances with Senators and thereby render themselves immune from removal. The doctrine reduced the "power of the President to a mere vapor; in which case his responsibility [for execution] will be annihilated." wss

Though a majority of the House concluded that the President ought to have authority to remove the Secretaries, this majority was split on the rationale. Adherents of the legislative grant theory believed that although the President ought to enjoy authority to remove, the Constitution had not granted such authority. Rather, Congress could (and ought to) vest the removal power with the President. Representative John Lawrence asserted that the Constitution left it up to the legislature to define the terms of office for executive officers. ${ }^{456}$ At the same time, however, he thought that the Constitution considered heads of departments "as the mere assistants of the President, in the performance of his executive duties." ${ }^{\text {"457 }}$ Though department heads might be mere assistants of the Chief Magistrate, it did not follow that the President could remove them at will.

Finally, the constitutional grant partisans maintained that the Constitution had answered all questions regarding removal of executive officers: The President's executive power granted the authority to remove executive officers. Echoing Washington's convictions, Fisher Ames affirmed that the Constitution

452. I ANNALS OF CONG.. supra note 2. at 383: see also HaRT. supra note 372, at 158 . Smith admitted, however, that inferior officers did not need to be impeached to be removed. 1 ANNALS OF CONG. supra note 2, at 383.

453. 1 ANNALS OF CONG., supra note 2, at 398.

454. Id. at 491 . Note that prior to the Constitution's ratification. Hamilon appeared to subseribe to this theory. The Federalist No. 77. at 459 (Alexander Hamilion) (Clinton Rossiter ed., 1961) (clauming that consent of Senate "would be necessary to displace as well as to appoint"). But see THE FEDERALIST No. 72, at 436 (Alexander Hamilton) (Clinton Rossiter ed., 1961) (insisting that officers executung laws were to "be subject to [presidential] superintendence." thus implying that President could remove them). 455. I ANNALS OF CONG., supra note 2, at 480.

456. Id. at 392-93. Representatives Lawrence and Sylvester invoked the Necessary and Proper Clause for the proposition that Congress could provide means for removal. Id. at 503. 583-84

457. Id. at 503 . 
put "all executive power in the hands of the President, and could he personally execute all the laws, there would be no occasion for establishing auxiliaries; but the circumscribed powers of . . one man, demand the aid of others." 498 The President possessed the executive power that gave him "all the powers properly belonging to the executive department of the Government . . . and such only taken away as are expressly excepted." ${ }^{, 459}$ One executive power was removal. ${ }^{460}$

Of course, opponents of presidential power vigorously challenged the constitutional grant theory. Representative White argued that the Executive only possessed the executive powers expressly mentioned in Article II, just as Congress only enjoyed the authorities listed in Article $\mathrm{I}^{461}$ Representative Jackson asserted that "[i]t requires more than a mere ipse dixit to demonstrate that any power is in its nature executive, and consequently given to the President of the United States." ${ }^{362}$ Giving the President the power of removal would make "all the officers the mere creatures of the President." ${ }^{263}$ Smith claimed the Article II, Section 1 argument "proves too much, and therefore proves nothing; because it implies that powers which are expressly given by the constitution, would have been in the President without the express grant." ${ }^{\text {"464 }}$ Smith asked, could the President establish corporations? Could he prevent citizens from leaving the country? Both were executive powers in England. ${ }^{465}$

Madison switched sides during the debate. ${ }^{466}$ Though at first he supposed that the Constitution did not itself require that department heads be removable at the pleasure of the President, ${ }^{467}$ he later joined the constitutional grant group. According to Madision, where the Constitution

has left any particular department in the entire possession of the powers incident to that department, I conceive we ought not to qualify them further than they are qualified by the constitution. . . .

The constitution affirms, that the executive power shall be vested in the President. Are there exceptions to this proposition? Yes, there are. The constitution says, that in appointing to office, the Senate shall be associated with the President .... . Have we a right to extend this exception? I believe not. If the constitution has invested all executive

458. Id. at 492 .

459. Id. at 561. If the President had only been granted "the executive power," he would "acquirc from that general expression all the powers properly belonging to the executive department." Id. at 561 .

460. Vining also argued that the executive power included removal authority. Id. at 388.

461. $l d$. at 485 .

462. Id. at 505 .

463. Id. at $505-06$.

464. Id. at 530 .

465. Id. at 566-67.

466. See generally HART, supra note 372 , at 178-84.

467. I ANNALS OF CONG., supra note 2, at 480-81. 
power in the President, I venture to assert that the Legislature has no right to diminish or modify his executive authority.

The question now resolves itself into this, Is the power of displacing, an executive power? I conceive that if any power whatsoever is in its nature executive, it is the power of appointing. overseeing, and controlling those who execute the laws. ${ }^{.68}$

Amidst this sea of conflicting congressional views, two points should not be lost. The First Congress, unlike Washington, was not of one mind regarding the administrative role of the President. Since the President had the executive power, which included the authority to superintend those who were statutorily empowered to execute federal law, many members recognized that the Constitution had altered the relationship between Congress and executive officers. Others, however, either refused to accept the Constitution's new institutional arrangements or failed to understand the new framework fully. These individuals may have become attached to obsolete Articles-ofConfederation conceptions. In any event, Lessig and Sunstein's fixation on statutes blurs these significant disagreements within Congress. By focusing on the text, neglecting the debates, and then devising a theory to explain these diverse statutes, Lessig and Sunstein convey the mistaken impression that "Congress" held one view of the President's executive power.

One should recognize also that no one in the House distinguished between administrative and executive departments or between administrative and executive laws-distinctions that Lessig and Sunstein purport to find in $5 \cdot$ atutes and in the Constitution itself. Nor did anyone distinguish administrative officers, such as the Treasury Secretary, from executive officers, such as the War Secretary. Instead, members of the House, no matter where they stood on presidential control, lumped together all departments and officers. Either all were under the President's control or none was.

The next Section surveys specific statutes with an eye toward examining how Congress "resolved" these differences in opinion. Congress apparently seesawed between an explicit acknowledgment that the Constitution contemplated a unitary, hierarchical Executive and silence on that matter. All the while, however, no statute explicitly enjoined presidential removal or presidential command of executive officers.

468. Id. at 481-82: see also HART, supra note 372, at 180-84. Madison also noted that the Constitution presumed that "the first Magistrate should be responsible for the executive department: so far therefore as we do not make the officers who are to aid him in the duties of that department responsible to him, he is not responsible to his country." I ANNALS OF CONG., supra note 2, at 479-80. Madison also commented on the implications of the President's Take Care duties: "If the duty to see the laws be faithfully executed be required at the hands of the Chief Magistrate, it would seem that it was generally intended that he should have the species of power which is necessarily 10 accomplish that end." including the power of removal. Id. at 479-80. 


\section{Administrative Practice Únder Certain Statutes}

Recall that under the Articles, the Congress was both the legislature and the Executive. It established different systems of administration. Congress chose whom to appoint to executive positions, and even though Congress lacked explicit removal authority, the power to appoint was thought to include an implicit grant of removal authority as well. ${ }^{469}$ Congress could also immediately superintend these officers. In short, Congress had the executive power-the authority to superintend directly the execution of its laws.

But the Constitution transformed all that. Congress could still create offices, but the President would have the power to appoint. In turn, the Senate could refuse to confirm. Congress might attempt to institute a system of administration, creating departments, boards, and secretaries along lines that it thought most appropriate; yet, if the President disliked a particular institution, he could veto it. Most important, if Congress did not approve of the way a particular law was being administered, it could not promptly command the relevant officer to alter his practices. A President who had directed the executive officer could veto any legislative attempt at meddling in executive details, and absent a supermajority in both chambers wishing to override the President's veto, the administrative policy in question could continue. Simply put, with the Constitution's creation of a Chief Executive who could wield a veto, Congress had lost its ability to superintend directly the administration of federal law. Executive officers were no longer the servants of Congress, but instead were all the President's men.

The only question was whether the First Congress would acknowledge that these executive officers, though created with the assistance of Congress, would be constitutionally subordinate to the President. Lessig and Sunstein assert that "[s]ome departments the framing Congress treated as purely executive, and others not; where the departments were not purely executive, Congress did not hesitate to create a degree of independence from presidential will." ${ }^{470}$ As the evidence below demonstrates, however, these assertions have only scant support. A more critical and thorough analysis of these statutes will disclose that Congress acknowledged presidential superintendence of all departments and institutions created in the early years.

Rather than examining every statute creating executive officers, we shall focus on the same institutions and officers that Lessig and Sunstein 
examine. ${ }^{471}$ Specifically, we shall survey the creation and operation of the Treasury Department, the Post Office, and the U.S. Altorneys.

\section{Was Treasury an Executive Department?}

Lessig and Sunstein make much of the fact that the Treasury Department was not originally constituted as an "executive" department. Though the President was mentioned in the first Treasury statute, he was referred to only in the context of removing the Secretary. ${ }^{47}$ Moreover, the Secretary was identified not as a "principal officer" but as a "head of department." "In sharp contrast, the acts establishing the Foreign Affairs and War Departments created "principal officers" in "executive Departments" who were explicitly made subject to presidential control. ${ }^{474}$

Lessig and Sunstein draw intriguing conclusions from their comparison of the three acts. The differences in language not only suggested that the First Congress did not consider Treasury an "executive" department, but also implied that Congress recognized that the Constitution distinguished "principal officers" from "department heads." Executive departments (led by principal officers) were those in which the President had a constitutional claim to authority, such as Foreign Affairs and War. In mere departments, such as Treasury, the President did not have any constitutionally mandated role, other than appointment of noninferior officers (such as the heads of those departments). The Treasury Act, we are told, reveals that "the first Congress considered the organizational form of the government to be mixed rather than unitary.",475

All this notwithstanding, we believe that the Treasury Department was an executive department. While some members of Congress may have wished to treat Treasury as a congressionally dominated department (as it was under the Articles and under the laws of many states), overwhelming evidence makes clear that Treasury was an executive deparment.

At the outset, the Lessig/Sunstein theory faces a good deal of difficulty because it cannot adequately explain why, a mere nine days after the enactment of the Treasury Act, the Treasury Secretary, the Comptroller, and other Treasury officers had salaries provided in a second act that established

471. We shall not examine the statute creating the second Bank of the United States and subsequent history because a statute enacted more than a quarier of a century after the Consutution's ratufication sheds little light on congressional original understandings. Iet alone on the ratifiers' ongınal understandings, of the Constitution.

472. Act of Sept. 2, 1789, ch. 12, § 7. I Stal. 65. 67: see 6 DOCUMENTARY HISTORY OF THE FIRST Federal CONGRESS OF THE UNTted STATES OF AMeriCA 1976 (Charlene Bangs Bickford \& Helen E Vell eds., 1986) [hereinafter FiRST FEDERAL CONGRESS].

473. Act of Sept. 2, 1789, ch. 12, § 1, I Stat. 65, 66.

474. Act of July 27, 1789, ch. 4, § I, 1 Stat. 28. 29: Act of Aug. 7. 1789, ch. 7. 1. I Stat. 49. 50; see Lessig \& Sunstein, supra note 1, at 34-35.

475. Lessig \& Sunstein, supra note 1 , at 28. 
salaries for "the Executive Officers of Government.,476 Did the first statute mistakenly omit that Treasury was an executive department and the second act merely correct that error, as Charles Thach has argued $?^{477}$ Or did the second statute mistakenly lump Treasury officials with executive officers? Or perhaps Treasury's executive officers were part of a nonexecutive department? In any case, the Salary Act casts serious doubt on the administrative/executive department distinction that Lessig and Sunstein attempt to draw. ${ }^{478}$ At the same time, however, we still confront the puzzling question of why Congress did not declare Treasury an "executive" department from the very beginning. Adumbrated histories of the Treasury Act and of the Philadelphia Convention's treatment of Treasury may resolve this question.

On June 4, 1789, several Representatives, including Madison, introduced the Treasury Bill. The bill sought to "establish an EXECUTIVE DEPARTMENT, to be denominated the TREASURY DEPARTMENT," whose numerous officers would be removable at the pleasure of the President. ${ }^{479}$ Although the Department was originally to be run merely by a "Secretary," the House agreed to add the explanatory phrase "to be the principal officer of the department. ${ }^{\circ 80}$ Before the bill was sent to the Senate, however, the title of the Act was altered to simply "AN ACT to establish the TREASURY DEPARTMENT" and the Secretary was now merely to be known as the "head of the department." ${ }^{\text {"48 }}$ Though the records of House proceedings fail to provide a reason for these alterations, the debates are nonetheless instructive.

Representative Page opened debate in the House, objecting that the bill as introduced empowered the Secretary to "digest and report plans for the improvement and management of the revenue, and the support of the public credit." ${ }^{, 482}$ Page declared that he could never support any law that permitted an "interference of an executive officer in business of legislation." Similarly, Representative Tucker argued that if "we authorize [the Secretary] to prepare and report plans, it will create an interference of the executive with the legislative powers." ${ }^{484}$ The Constitution had provided the only means of communicating between the Congress and an executive department: The

476. Act of Sept. 11, 1789, ch. 13, § 1, 1 Stat. 67, 67.

477. ТHACH, supra note 82 , at 144-45.

478. Although Lessig and Sunstein acknowledge the existence of the Salary Act, see Lessig \& Sunstein, supra note 1, at $27 \mathrm{n} .123$, they do not attempt to make sense of it within the context of their theory. This is particularly odd since their claims rely so heavily on the assertion that Congress supposediy created a nonexecutive department.

479. 6 FIRST FEDERAL CONGRESS, supra note 472, at 1980.

480. 6 id. at 1980 n.4.

. 481. $6 \mathrm{id}$. at 1983.

482. I ANNALS OF CONG., supra note 2, at 592.

483. Id. at 594 (emphasis added).

484. Id. (emphasis added). Elbridge Gerry opposed the bill because if Congress permitted the Secretary to report plans to Congress, it would be granting an "indirect voice in legislative business to an executive officer" and thus be "giving [a] great degree of importance" to an executive officer. $I d$. at 601 (emphasis added). 
President had the duty to deliver information to Congress on the State of the Union and to submit legislation. ${ }^{485}$

The discussion surrounding the Treasury Secretary's duty to prepare and submit reports to Congress makes clear that at least some members of the House considered the Secretary (and presumably other officers in his department) to be an executive officer (thus suggesting that the Salary Act was not an anomaly). ${ }^{486}$ Worried about the possible influence this executive officer would have when presenting reports to Congress, opponents of the duty to report sought to distance him from Congress. ${ }^{487}$ Yet if the Treasury Secretary was an executive officer, why was the title of the Act subsequently altered? Once again definitive conclusions are elusive.

Clues as to why the title of the Act was altered can be found by stepping back and examining the position of Treasury at the Philadelphia Convention. The Pinckney plan, which provided that the "Head[] of the Department[] of Treasury" would sit on a "Council of Revision" and that Congress would create all offices and appoint individuals, ${ }^{488}$ was sent to the Committee of Detail, which reported out a congressional power to "appoint a Treasurer by ballot." 489 In the ensuing debate regarding ballot selection of the Treasurer, Delaware Delegate George Read argued that the legislature was not fit for making appointments and motioned to strike the clause "leaving the appointment of the Treasurer as of other officers to the Executive." The Chief Magistrate "being responsible would make a good choice." disagreed. Because the federal government's money belonged to the people, their representatives (the legislature) "ought to appoint the keepers of it." Read's motion, though seconded, lost. ${ }^{492}$

In the waning days of the Convention, John Rutledge sought to strike the clause. ${ }^{493}$ Governeur Morris concurred, noting that the Treasurer would be "more narrowly watched, and more readily impeached" if Congress did not appoint. ${ }^{494}$ Demurring, Gorham and King admonished that the "people are accustomed \& attached to that mode of appointing Treasurers, and the

485. Id. at 594.

486. To our knowledge, no one suggested that the Secretary was not an executive officer.

487. Indeed, these opponents of permitting the Secretary to make reports to Congress eventually had that language altered. Instead of the authority to make "repon plans" for the improvement of revenue to Congress, the Secretary could only "prepare" plans. I ANNALS OF CONG., supra note 2. at 607. Presumably. that would prevent the Secretary from coming to the floor of the House or Senate to make a report.

488. 2 Federal CONVENTJON, supra note 134. at 135-36. For attribution to Pinckney, sec 2 id. at 134 ก.3.

489. 2 id. at 182 . Note that the Committee of Detail also reported language staung that the Prestdent would appoint all officers "not otherwise provided for by this Consutution." 2 td. at 185.

490. 2 id. at $314-15$.

491. 2 id. at 315 .

492. Id.

493. 2 id. at 614 .

494. Id. Similarly, Pinckney maintained that legislative appointment made legtslatures unwilling to discipline their own officers. Id. 
innovation will multiply objections to the System" if the President had this power of appointment. ${ }^{495}$ Roger Sherman thought that since the Congress would appropriate, it ought to appoint the officer who would disburse. ${ }^{496}$ As we know, supporters of congressional appointment lost. ${ }^{497}$ Since the Constitution would not provide for the appointment of a Treasurer, the President would make the appointment. ${ }^{498}$

The House's alterations to the Treasury Bill as introduced suggest that some Representatives may have wished to make Treasury a congressionally dominated department once again, as it had been under the Articles, ${ }^{499}$ and as it was under many state constitutions. ${ }^{500}$ Though opponents of a robust Executive recognized that Treasury was an executive department (witness their numerous statements labeling the Secretary an executive officer), once they successfully altered the Secretary's reporting power, perhaps they grew emboldened and attempted to remove Treasury from the Chief Executive's orbit by no longer classifying it as an "executive" department. ${ }^{501}$

495. Id.

496. Id.

497. Id.

498. Note that this change was foreshadowed, for the final discussion of congressional appointment of a Treasurer occurred against the backdrop of previous comments from several delegates that the Secretary of Treasury would be subordinate to the President. The Morris-Pinckney Council of State, which would "assist the President in conducting the Public affairs," would have created a "Secretary of Commerce and Finance" who would serve the President "during pleasure." 2 id. at 335-36 (Secretary would "superintend all matters relating to the public finances, and prepare and report Plans of revenue and for the regulation of expenditures"). Indeed, it was Morris who had noted that "the minister of finance" would be subordinate to the President. $2 \mathrm{id}$. at 54 . An executive officer, whether designated the Treasurer or Treasury Secretary, would be executing laws and ought to be appointed by the Chief Executive who would be, after all, in charge of the execution of all federal laws. Though the Convention did not immediately eliminate the provision providing for a congressionally appointed Treasurer, enough delegates eventually recognized its inconsistency with the responsible, unitary Executive. Defenders of legislative prerogative lost by a lopsided three to eight vote. 2 id. at 614.

499. SANDERS, supra note 225 , at 151.

500. Learned argues that the Treasury Act's peculiar language was "due to general recognition of the force of popular tradition and colonial precedent in the matter of financial administration." Prior to the Constitution, "financial administration had been all but completely within the control of the popular bodies." LEARNED, supra note 223 , at 101.

501. McDonald contends that the House added restrictions to the Secretary's powers in order to bind the Secretary to the will of the House, rather than of the President. MCDONALD, PRESIDENCY OF GEOROE WASHINGTON, supra note 368, at 36-37. Casper observes that Congress did not affirmatively prohibit presidential superintendence. Rather, it imposed legal duties on the Secretary, something that was not done with the departments of War or Foreign Affairs. Casper, supra note 246, at 241.

Indeed, anachronistic Articles-of-Confederation thinking seemed to infect both sides. As Representatives Livermore and Madison recognized, the original bill created a Treasury Secretary with duties very similar to those of the Continental Congress' Superintendent of Finance. Representative Livermore observed that the reporting requirements were derived from Continental Congress precedent. I ANNALS OF CONG., supra note 2, at 605. The former Superintendent of Finance had such authority, and the authors of the bill had merely copied from the old statute, failing to recognize

the different circumstances of the present and former Congress; . . . [the former Congress] possessed the legislative and executive power; they could abolish his plans and his office together, if they thought proper; but we are restrained by a Senate, and the negative of the President. We have no power over him ....

Id. at 598. Given the changed circumstances, Congress ought not to place "dangerous powers into" the Secretary's hands. Id. Madison also observed that the language of the bill derived from language passed 
Or maybe the alteration of the Treasury Act's title was without significance. After all, prior to the title change, opponents of the Secretary's power to report plans to Congress recognized that the Secretary was an executive officer. ${ }^{502}$ But whatever the First Congress' understanding of the Department, Treasury was an executive department because its personnel executed federal law-the quintessential function of an executive department. Treasury would be collecting levies and disbursing funds-in other words, executing the nation's tax and appropriation laws.

Washington had just such an understanding of Treasury's position. From the beginning, Washington asserted his constitutional authority over the Treasury Department. ${ }^{503}$ Washington unmistakably understood that the Constitution empowered him to superintend the execution of appropriation and tax laws.

Nor did Hamilton attempt to gain a measure of independence from the Chief Magistrate. ${ }^{504}$ As Forrest McDonald notes, "[i]n administrative matters that were clearly executive [such as] the short-range borrowing and disbursal of funds . . . Hamilton continued to report directly as a subordinate and to act only upon orders from" Washington. ${ }^{505}$ Indeed, one of Hamilton's most memorable deeds was in response to an order from Washington: the opinion on the constitutionality of the Bank of the United States. In that opinion, Hamilton clearly notes that he is responding to Washington's "order." $\$ 00$ Given the lack of statutory language authorizing Washington to "order" Hamilton, Washington's authority must have come from the Opinions Clause of the Constitution, which by its own terms applies to executive departments.

by the 1783 Continental Congress. Id. at 604 . In other words, the pro-unttary Executuve authors of the bill seemed to be unconcerned that what was entirely appropriate in another context. that is. having a Secretary report to Congress, was perhaps inappropriate when the Secretary served a new master. the President. Perhaps their comments about the Continental Congress" control of the administration of the Treasury may have rekindled a desire on the par of some wistful members to recapture the mighty executuve/legislauve powers wielded by the Continental Congress. The subsequent Salary Act might be seen then as a successful pro-unitary Executive counterrevolution that overcame opposition to callung Treasury an executuve department.

502. Casper provides yet another reading. Hamilton may have desired direct dealıngs with Congress and some independence from the President, and thus he may have been the originator of the odd Treasury language. Casper, supra note 246, at 227-28.

503. Recall that upon becoming President, Washington wrote to the Board of Treasury to garner an accurate understanding of the administrative business of the United States. See HaRT. supra note 372. at 135. As noted earlier, he advised Hamilton on the structure of an agency that would collect revenue. WHITE, supra note 236 , at 33 . In addition, he regularly conveyed his approval or disapproval of Hamilton's plans or actions. For instance. "[t]he appointment of that gentleman to negotiate the Loans in Holland. and the Instructions you have given for his government, meet my approbstion." 31 WRIntias of GeORGE WASHINGTON, supra note 423 , at 118.

504. White claims that Hamilton. like all department heads, never "settled any matter of importance without consulting the President and securing his approval." WHITE, supra note 236. at 27

505. Ḿ́CDONALD. PRESIDENCY OF GEORGE WASHINGTON, supra note 368. at 65.

506. Alexander Hamilton, Opinion on the Constitutionality of an Act To Establish a Bank. in PAUL

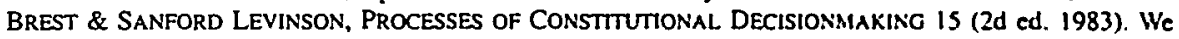
are indebted to Professor John Harrison for bringing this point to our attention. 
Focusing on the language of the Treasury Act, Lessig and Sunstein have largely ignored the Act's legislative history, subsequent administrative practice, and the ramifications of the Salary Act. As a result, their interpretation of the Treasury Act suffers. Yet they do examine legislative history regarding the Treasury Comptroller. As Lessig and Sunstein point out, Madison moved to modify the Comptroller's tenure, asserting that the Comptroller-who would decide "upon the lawfulness and justice of the claims and accounts subsisting between the United States and particular citizens"-possessed judicial and executive qualities. ${ }^{507}$ When an officer was a blend of executive and judicial functions, he believed, Congress could modify that officer's tenure. ${ }^{508}$ Accordingly, Madison's Comptroller would have held office for a fixed number of years "unless sooner removed by the President." 509

The response to Madison's proposal is instructive: incredulity. ${ }^{510}$ Representative Benson said the issue of tenure had already been settled: Judges would hold office during good behavior, while all others would serve at the pleasure of the President. ${ }^{511}$ Attempting to insulate executive officers from the Chief Executive might enable Congress to "overthrow the executive

507. I ANNALS OF CONG., supra note 2 , at 611 .

508. Id. at 612 .

509. Id. Madison's proposed tenure "modification" was rather odd. The tenure of Madison's Comptroller was not markedly different from the tenure of other officers. Moreover, all officers, including the Comptroller, would be removable by the President. Officers other than the Comptroller, however, would enjoy potentially limitless tenure. If a subsequent President wished to keep them in office, he would not have to reappoint them and subject them to Senate confirmation a second time. The Comptroller, however, because he was to have a fixed term, could be subject to more frequent confirmation proceedings. Madison seems to have recognized that his tenure proposal would have this effect:

[T] he Comptroller would be dependent upon the President, because he can be removed by him;

he will be dependent upon the Senate, because they must consent to his election for every term of years; and he will be dependent upon this House, through the means of impeachment, and the power we shall reserve over his salary; by which means we shall effectually secure the dependence of this officer upon the Govemment.

Id. Madison's justification for modifying the Comptroller's tenure would seem to be in tension with his actual tenure proposal. As noted above, Madison thought that since the Comptroller would have ccrtain "judicial" duties, a modification of tenure was in order. That would seem to suggest that more independence from the political branches was the order of the day. Yet Madison strangely proposed a tenure modification that he acknowledged would lead to a Comptroller more subject to the whim of the political branches and thus less independent.

Moreover, all officers (except judges and the President) are beholden to Congress for the provision of salaries. Thus it is hard to see exactly what additional control Congress would gain by specifying the tenure of the Comptroller. If Congress wished, it could always refuse to fund the Comptroller's activities, thus effectively firing the existing Comptroller. It could simultaneously create a new office, labeled Treasurer, which would undertake all the functions previously exercised by the Comptroller. The President would then have to subject either the old Comptroller or a new appointee to new confirmation hearings. Madison's discussion of the Comptroller, then, reflects uncharacteristic confusion on two separate levels, both of which call into question his understandings. Gerhard Casper has also noted the oddity of Madison's proposal. Casper, supra note 246, at 238.

510. Representative Smith, an avid proponent of the impeachment theory of removal, would have done Madison one better, arguing that the Comptroller ought to be completely independent of the Executive. 1 ANNALS OF CONG., supra note 2, at 613.

511. Id. at 614. Representative Stone also thought that "all officers, except the judges, should hold their offices during pleasure." Id. at 613. 
power." ${ }^{\text {}} 12$ Representative Sedgwick also agreed that a majority had already determined that executive officers should only hold office at pleasure. ${ }^{313}$ After all, he said, "they were the eyes and arms of the principal Magistrate, the instruments of execution." 514 The Comptroller ensured "the regular and punctual payment of all moneys which may be collected, and [directed] prosecutions for delinquencies," and was thus an executive officer." Though that debate adjourned with Madison once again reasserting his carlier position, Madison withdrew his Comptroller tenure motion the very next day. ${ }^{310}$ Given the vehement response from unitary executivists such as Benson and Sedgwick, and Madison's subsequent retreat, attempting to use Madison's Comptroller motion for the proposition that the First Congress contemplated an executive/administrative distinction seems rather suspect. ${ }^{517}$

Lessig and Sunstein are unable to cite any statutory language or history supporting the notion that the Comptroller "was not directly within the President's control"; they rely instead upon commentators. ${ }^{\text {sI }}$ Yet there is no language in the Treasury Act to support the theory that the Comptroller was not an executive officer, subject to presidential direction. As the above debate reveals, members of Congress understood the Comptroller to be an executive officer. $^{519}$ Moreover, a perusal of the Salary Act for executive officers confirms that Congress considered the Comptroller to be an executive officer. $^{520}$ The case for an independent, nonexecutive Comptroller ${ }^{511}$

512. Id. at 613 .

513. Id.

514. Id.

515. Id.

516. Id. at 615. Why Madison withdrew his amendment remains unclear. Concetvably. Sedgwick and Benson's powerful arguments swayed him. The Comptroller would execute federal law, after all. Did this not make him an executive officer. superintended by the President? Of course. we may never know precisely why Madison withdrew his amendment. His retreat may well have been merely taclucal. He may, for example, have clung to his beliefs but sensed defeat, deciding instead to withdraw his motion.

517. Lessig and Sunstein acknowledge that opponents of the unitary Exceutuve theory have made 100 much of Madison's tenure proposal. See Lessig \& Sunstein, supra note 1. at $17 \mathrm{n} .70$. Yet, they too seem trapped in this pitfall. See id. at 28-29 (quoting Madison's proposal in order to show congressional understanding that "Congress has the authority to immunize [some] agencies from presidential control").

518. See id. at 27 n. 124.

519. The only two who expressly reject this position are Madison. who subsequently withdrew his Comptroller amendment, and Representative Smith, who clung to his fantastic notion that all officers created by Congress should be independent of the President. See I ANNaLS OF CONG., supra note 2, at 612-14. Thus, Lessig and Sunstein's assertion that "not all" shared Madison's views about so-ealled quasijudicial officers is an extreme understatement. No one but Smith vosced any support for the notion.

520. Act of Sept. 11, 1789, ch. 13, § 1, 1 Stat. 67, 67.

521. Lessig and Sunstein maintain that the Treasury Act "shielded the Comptroller .. from presidential direction." Lessig \& Sunstein, supra note 1, at 27. The Treasury Act, however, contasns no explicit provision that shields the Comptroller from presidential superintendence. Instead. Lessig and Sunstein infer the Comptroller's independence from statutory language requinng both the Comptroller's and the Treasury Secretary's signature on warrants for money. See id. at $28 \mathrm{n} .124$. Under the Treasury Act, the Secretary has authority to issue "all warrants for monies ... from the Treasury. in pursuance of appropriations by law," but the Comptroller was to "countersign all warrants drawn" by the Secretary. Act of Sept. 2, 1789, ch. 12, $\$ \$ 2,4,1$ Stat. 65, 66. Based on this countersignature requirement. Charles Tiefer has argued that the Comptroller must have been independent. Charles Tiefer. The Consuiturionality of Independent Officers as Checks on Abuses of Executwe Power. 63 B.U. L. REV. 59. 73-74 (1983). Surely 
seemed rather flimsy, and ended with Madison's capitulation to Representatives Sedgwick and Benson. ${ }^{522}$

if the Comptroller were subordinate to the Secretary, the argument goes, such countersignature would have been superfluous.

This argument suffers from two flaws. First, the countersignature requirement does not necessarily indicate that the Comptroller was independent from the Secretary. Countersignature requirements where onc officer is clearly subordinate to the other are common in business. The requirements stem from the commonsense notion that embezzlement is more difficult if two officers must sign before money can be disbursed. Indeed, under the Articles of Confederation, the Continental Congress had sirnilarly required that the "Register" countersign warrants whether they came from the Treasurer, the Superintendent of Finance, or the President of Congress. See SANDERS, supra note 225, at 133.

Second, even if the Treasury Act contemplated a Comptroller who was independent of the Sccretary. that says nothing about whether the Comptroller was independent of the Chief Executive. Two exccutivc officers can be independent of each other without violating the unitary Executive theory. The Constitution only dictates that both be subordinate to the Chief Magistrate.

Tiefer also cites a 1795 statute for the proposition that the President could not direct the Comptroller. See Tiefer, supra, at 74. That statute stated that Comptroller decisions regarding claims the United Statcs held against individuals who had received funds from the Treasury were "'final and conclusive."' Id. (quoting Act of March 3, 1795, ch. 48, § 4, 1 Stat. 441, 442). Tiefer concludes that since the Comptroller's decisions were "final and conlusive," the President could not superintend the Comptroller. He argues that the federal judiciary, however, could overtum the Comptroller's decisions. Id. at 74 n.65.

Tiefer's conclusions suffer from several defects. First, making Comptroller decisions "final and conclusive" may imply that the President cannot direct the Comptroller after a decision is made, but that in no way suggests that the President cannot direct the Comptroller before any decision is made. Second, and more importantly, it seems to us that Tiefer's claim about finality vis-d-vis the judiciary is backwards. Most likely, the Comptroller's decisions were made "final and conclusive" because there was to be no judicial review of his actions. That would explain Madison's views. Since the Comptroller would be making final decisions regarding "the lawfulness and justice of the claims" between the United States and citizens, the Comptroller possessed judicial qualities. See supra notes 507-09 and accompanying text. That the decisions were final and conclusive with respect to the judiciary, however, does not mean that they were final and conclusive with respect to the President.

We observe that the Continental Congress' Comptroller also had the authority to settle claims the United States had against those who managed federal monies. See SANDERS, supra note 225 , at 133 . These decisions were also "final." Id. In the context of the Continental Congress, finality made sense because there was no federal judiciary to oversee these decisions. Evidently, Congress wanted such administrative finality to continue under the Constitution, notwithstanding the existence of the Supreme Court and the statutory creation of inferior federal cours.

In any event, we have yet to see any evidence that, in the early years of the Republic, the Comptroller was independent of the President.

522. The President's control of Treasury does not contradict the notion that the Executive ought not to have the power of both purse and sword. See Lessig \& Sunstein, supra note 1, at 82 . The President has the power of the sword (e.g., the Commander-in-Chief authority), but Congress may refuse to appropriate funds and thereby keep that sword sheathed. Similarly, the President has the authority to execute only appropriation acts, not the power to appropriate itself. Though located in the first Article, Section 9, Clausc 7 seems to speak to executives: "No Money shall be drawn from the Treasury, but in Consequence of Appropriations made by Law." U.S. CoNST. art. I, $\$ 9$, cl. 7. The Anti-Federalist "Impartial Citizen" said as much: "Nor can [the President] appropriate the public money to any use, but what is expressly provided by law." 8 DOCUMENTARY HISTORY OF THE RATIFICATTON, supra note 225, at 295. Hence, even with presidential control of Treasury, Congress still controls the purse; it may choose to take a few coins from the public's purse and give them to the Executive to expend according to law. Without this congressional decision, however, the President may not even reach into the purse. Lessig \& Sunstein, supra note 1, at 82.

Moreover, if there was any congressional concern about presidential "control" of purse and sword that animated the decision not to label Treasury an executive department in the Treasury Act, Congress expressed it rather haphazardly. Statutes of the first several Congresses repeatedly endowed the President with both appropriation and debt authority. See Act of March 26, 1790, ch. 4, \& 3, 1 Stat. 104, 105 (authorizing President to draw from Treasury $\$ 10,000$ for contingent government expenses); id. $\$ 7,1$ Stat. at 105-06 (authorizing President to empower Secretary of Treasury to take on new loans as may be necessary to fund appropriations); Funding Act of Aug. 4, 1790, ch. 34, § 2, 1 Stat. 138, 139 (authorizing 
Lessig and Sunstein's discussion of the differences in phrasing between the Treasury Act and the two other departmental acts, and of Madison's statements regarding the Comptroller's tenure, raises fascinating questions. Some members of Congress, relying upon the history of the Articles period or state practices, may indeed have believed that Treasury was "theirs" to control. But when viewed in the context of the legislative history and administrative practice, the Treasury Act offers little support for Lessig and Sunstein's theory. Rather, there is much that bolsters our claim.

\section{Post Offices and the President}

In their analysis of the Post Office, Lessig and Sunstein once again insist that Congress did not believe that the administration of all federal law had to be superintended by the President. ${ }^{523}$ Since the Post Office would be executing a power of Congress (the postal power), they argue, it could be independent of the President. ${ }^{524}$ As they acknowledge, however, though the Second Congress did not explicitly sanction presidential control over the Post Office, the First Congress did. It temporarily established a Post Office and a Postmaster General who would "be subject to the direction of the President of the United States in performing the duties of his office." ${ }^{\text {"2s }}$ In contrast, the 1792 Postal Act made no mention of presidential superintendence of the Postmaster. From this difference in language (and from the 1798 establishment of the Navy Department as an executive department), Lessig and Sunstein conclude that Congress sought to isolate the Post Office from presidential control and that Congress did not believe that the postal administration had to be under presidential superintendence. ${ }^{526}$ As with the supervision of Treasury, however, this claim is suspect.

Had Congress wished completely to isolate the Post Office from presidential influence, it would have affirmatively prohibited executive direction. Given that Washington treated the Post Office like every other executive department prior to the 1792 Act-namely as a presidentially controlled institution-if Congress wanted to grant the Post Office autonomy,

President to borrow $\$ 12$ million to help pay interest on forcign debt): Sinkıng Fund Act of Aug. 12. 1790 , ch. 47, 1 Stat. 186 (authorizing President to borrow \$2 million to retire existing U.S. debt); Act of March 3, 1791, ch. 15, § 58, 1 Stat. 199, 213 (authorizing President to determine pay of supervisors and inspectors assigned to execute and enforce duties on imported spirits). The list of instances where Congress directly empowered the President to "meddle" in fiscal matters gocs on and on.

We do not believe that a purse-and-sword fear animated the peculiar wording of the Treasury stalute, and we find it significant that the only evidence that Lessig and Sunstein cate for that proposition is a comment by Henry Clay some 50 years after the enacument of the Treasury Act. Lessig \& Sunstein, supro note 1 , at 82 . While Clay is undoubtedly a good source for congressional intent of his own pernod, he seems an inappropriate choice of authority for the Treasury Act.

523. Lessig \& Sunstein, supra note 1, at 29-30.

524. Id. at 30 .

525. I ANNALS OF CONG., supra note 2. at 2179.

526. Lessig \& Sunstein, supra note 1, at 29-30. 
language to that effect would have made its intentions evident to the President. As enacted, the 1792 Postal Act said nothing whatsoever barring the President from directing postal affairs. The lack of such language ought to prompt us to question Lessig and Sunstein's underlying premise, for they seem to argue no more than that the absence of a congressional prohibition upon presidential control signifies that Congress meant to preclude it.

There is an alternative explanation for the omission of a statement relating to presidential superintendence: Perhaps it was so well understood that the President was constitutionally empowered to control the Post Office that a statutory provision to that effect was unnecessary. Having established from the first Act that Congress understood that the President could control the Postmaster General (and by implication the Post Office), it was superfluous to repeat the obvious in the subsequent reauthorization bill.

Debate on the postal bill supports this interpretation. In discussions regarding whether the President or Congress ought to have the authority to designate post roads, members contemplated that the President would superintend the Postmaster General. Representatives treated the President and the Postmaster interchangeably, implicitly acknowledging that though the President would be granted explicit authority to designate post roads, he could delegate such authority to his assistant, the Postmaster General. Representative Sedgwick, who proposed giving the President the post road authority, said that when the previous Congress had considered this subject, the sense of the House had been to delegate the power to the President. "[T]he only difference had been with respect to the mode of expression-but the effect was still to have been the same-some gentlemen thinking it best to leave the details of this business entirely to the supreme Executive, others wishing to name the Postmaster General." 527

Opponents of ceding the post road authority to the President also understood that the Postmaster General would be subject to presidential control. Representative Livermore argued that if the President could select post roads, Congress might as well pass a law empowering the Postmaster to "have the whole government of the post office." 528 Similarly, Representative Hartley noted that if the President could pick post roads the whole postal administration would be "thrown into the power of the Executive." 529 Hartley also warned that through the Post Office, the President could obtain "a weighty influence" throughout the nation. He lamented that the bill did not guard

527. 2 ANNALS OF CONG., supra note 106, at 229 (1791) (emphasis added). Representative Bourne similarly thought the President and the Postmaster would be better able to select post roads than Congress, thus indicating that he saw an identity of interest between the Postmaster and President. Id. at 232.

528. Id. at 230 . In other words, by empowering the President to select post roads, Congress would effectively transfer a great power to the Postmaster. The Congress could just as well give the Postmaster plenary control.

529. Id. at 231 . 
against such prospects. ${ }^{530}$ In other words, the bill did not bar the President from extending his influence throughout the country by means of the Post Office. Thus the lack of statutory authority to superintend the Post Office was not thought to preclude presidential control. Rather it was understood that the President would continue to direct postal affairs. ${ }^{531}$

President Washington also perceived that he was constitutionally authorized to administer the nation's postal laws. Recall that when Washington became President, he asked the Postmaster General (along with the other department heads) to provide a detailed account of the Department and its business. $^{532}$ In July of 1789 , the President, believing that the Post Office was not generating enough revenue, commanded the Postmaster General to send " in detail, the receipts and expenditures of the Post Office" for the years 1784 and $1788 .^{533}$ In 1791 , Washington, by administrative fiat, made the Post Office a subunit of the Department of Treasury. ${ }^{534}$ Since the Post Office brought in stamp revenue, the Post Office properly belonged in Treasury. ${ }^{535}$

Though Lessig and Sunstein insist that Congress "removed the language making the Postmaster General subject to the direction of the President," 536 nothing of the sort occurred. Rather than enacting a law that repealed the existing postal act's provisions regarding presidential control, Congress enacted a wholly new act that was silent as to presidential superintendence. By claiming that Congress specifically "removed" the presidential direction language, Lessig and Sunstein suggest that Congress focused on this provision and consciously decided to repeal it. We see no evidence of such an intent animating Congress. ${ }^{537}$

530. Id. at 232.

531. Note that Harley's comments indicate that he thought that Congress could enact laws to prevent the President from obtaining too much influence in the Post Office. Whether this meant that Congress could preclude presidential control or merely enact laws to prevent malfeasance, nepotusm. and comuption is unclear.

532. HART, supra note 372 , at 135 .

533. Id. at 136.

534. WHITE, supra note 236 , at 30-31, 226-27.

535. See id. White notes that after the passage of the 1792 Act. Jefferson tned to convince Washington to move the Post Office from Treasury to the State Department. Washington declined. The incident show's that Jefferson recognized that Washington controlled the Post Orfice. See id. at 226-27.

McDonald asserts that Washington was not as involved in postal affairs as he was in the other departments. MCDONALD. PRESIDENCY OF GEORGE WASHINGTON, supro nole 368. at $41-42$. The lack of vigilant supervision might reflect Washıngton's sensitivity to charges that he would use the postal department as a means of extending his influence throughout the nation.

536. Lessig \& Sunstein, supra note 1, at 29.

537. As in their Treasury discussion, Lessig and Sunstcin cite no relevant authonty for the proposition that a purse-and-sword concem motivated Congress when it repealed the presidentual supenntendence provision. They cite only a statement from George Mason at the Philadelphia Convention on the need to keep sword and purse separate generally. See id. at $30 \mathrm{n} .137$. Importing Mason's generic comment into a wholly alien context hardly constitutes evidence of a congressional concern with vesting purse and sword in the Executive.

To be sure, there were concerns about sword and purse at the Founding. The Ant1-Federalist Samuel lamented the fact that the President and Congress shared the power of the purse and the sword. 4 ANT1. FEDERALIST, supra note 277, at 193. But see THE FEDERALIST No. 78. at 465 (Alexander Hamilton) 
Once one grasps some background facts, the absence of language confirming executive control of the Post Office is easy to explain: Everyone presumed that the President would superintend the Post Office and thus it was unnecessary to include such language. The Post Office would be executing the nation's postal laws and therefore had to be subject to executive control.

\section{The Prosecutorial Power and the President}

Although unitary executivists maintain that prosecution is a core executive function, Lessig and Sunstein assert that the original understanding does not support this proposition. The U.S. Attorneys, created in the Judiciary Act to prosecute suits on behalf of the United States, were not put explicitly under the control of the Attorney General or the President. ${ }^{538}$ In practice, the attorneys acted under the control of the Comptroller with respect to ensuring that the debts owed the United States were promptly paid. ${ }^{539}$ But, we are told, not only were public prosecutors free from presidential direction, but private citizens also could bring qui tam actions against individuals, and thus even private citizens had federal prosecutorial authority. Lessig and Sunstein claim that these "bits of history are devastating to the modern unitarian's originalist claims about prosecution." 540

We disagree. Notwithstanding the lack of any language mentioning presidential superintendence, administrative practice suggests that President Washington thought he could control prosecutors. Indeed, as we shall see, English practice also supports the notion that the Executive controls prosecutions.

Lessig and Sunstein are entirely correct in observing that U.S. Attorneys exercised a great deal of independence and were placed only at the service of the Comptroller in bringing actions against those who owed the federal government money. ${ }^{541}$ Indeed, Washington's Attorney General, Edmund Randolph, recognized his lack of authority to direct the attorneys: "[T]he want of a fixed relation between the attorneys of the districts and the Attorney General[] has rendered it impossible for me to take charge of matters on which I was not authorized to give instructions." 542 Though the Attorney General might seem the most obvious officer to direct the U.S. Attorneys (after all, he

(Clinton Rossiter ed., 1961) (suggesting that the President controls the sword, Congress the purse, and the courts neither). But once again, presidential direction of those who collect revenues pursuant to an act of Congress does not constitute executive control of the purse. When Congress tells the President how to collect funds and then tells him how to spend the funds, Congress still holds the purse.

538. Act of Sept. 24, 1789, ch. 20. $\$ 35,1$ Stat. 73, 92.

539. Lessig \& Sunstein, supra note 1, at 17.

540. Id. at 20.

541. Id. at 17.

542. WHITE, supra note 236, at 167. Though Washington requested that Congress grant the Altorney General supervisory powers cver the attorneys, his proposal went no further than a favorable committec report. Id. at 168. 
was the "general" of the attorneys), historian Leonard White contends that the Secretary of State played a much more significant role in the early days of the Republic, while admitting that the Secretary did not direct attorneys to bring suit either. ${ }^{543}$

But even if subordinate executive officials could not direct U.S. Attorneys, their lack of authority in no way undermines the unitary Executive. The Secretary of State and the Attorney General were mere creatures of law; they only had such authority as the law granted them and the President ceded. The key question, which seems not to have been confronted, is whether U.S. Attorneys could have refused to accept a direct order of the President either to prosecute or to cease a prosecution. Clearly, the President lacked express statutory authority to direct the U.S. Attorneys. But he did not need such authority, for his authority flowed from a higher source: the Constitution's grant of "executive power."

In fact, Washington did exercise such authority over the U.S. Attorneys. One volume of Washington's writings reveals that Washington "instructed" the attorney for the Pennsylvania district to nol-pros an indictment against the two individuals who had been accused of rioting; ${ }^{544}$ he also directed the Attorney General "to instruct the District Attorney to require from the [Revenue] Collectors of all the several Parts ... information of all infractions lof the Neutrality Proclamation] that may come within their purview." Constrary to Lessig and Sunstein's assertion, then. Thomas Jefferson was not the first President to assert control over prosecutors. ${ }^{546}$ Presidential superintendence of federal prosecution was asserted from the very beginning. ${ }^{57}$

543. See id. at 406. The Secretary of State directed legal actions agannst pnvateers and foreign vessels. Id. at 407. In the John Adams Administration. Secretary of State Timothy Pickenng read opposition newspapers and passed on seditious items to U.S. Altomeys, so that individuals could be prasecuted under the Alien and Sedition Acts. Id. Pickering also occasionally asked U.S. Altorneys to discontinue suts against foreign officials. $l d$. at 408 .

544. In other words, Washington ordered a district attorney to discontunue prosecutuons. 32 WRmkGs OF GEORGE WASHINGTON, supra note 423, at 455 n.35.

545. 32 id. at 386. Washington had earlier asked Hamilton about the wisdom of directing the Altomeys to prosecute violations of the Neutrality Proclamation. Apparently Washinglon had made up his mind.

546. See Lessig \& Sunstein, supra note 1, at 18 n.75, 22 n.92.

547. Professor Krent has argued that there was a lach of "centralized control withun the exccutuve branch over criminal law enforcement." Harold J. Krent, Executuve Control over Craminal Law Enforcement, 38 AM. U. L. REV. 275. 286 (1989). Following Leonard White's lead. Krent notes that the Attomey General lacked supervisory authority and that the Secrelary of State assumed "utular responsibility" for supervising district attomeys. ld. at 289.

The problem with Krent's argument is that it confuses Congress' perceived unwillingness to grant supervisory authority to a creature of statutory law (such as the Attomey General) with executive inability to direct district attomeys. As Washington's actions confirm, notwithstandıng congressional faulure to create an officer who would supervise district attomeys. the President had such authonty secured by the Constitution.

Krent's point about the lack of centralization. however. is not without force. In an era of poor communication and long joumeys, we might expect that executuve officers in the hinterland received less instruction and direction from President Washington than they would have if communication and travel had been easier. Thus marshals, revenue collectors, postal officials, and so forth had a great deal of latutude in executing their duties. That latitude, driven by the simple fact of poor communicalsons, however, says little 
English understandings of the prosecutorial power confirm that such authority rests with whomever has the executive power. Blackstone clearly considered prosecution to be part of the power to execute laws. Though violations of the law "seem . . . to be rather offences against the kingdom than the king; yet, as the public ... has delegated all it's [sic] power and rights, with regard to the execution of the laws, to one visible magistrate," 548 such infractions should be considered affronts to the Chief Magistrate to whom the public has delegated its right to execute. The Executive is "therefore the proper person to prosecute for all public offences and breaches of the peace, being the person injured in the eye of the law." delegated to the President the right to execute the laws, we at the same time empowered him to prosecute those who transgress the law. The right to prosecute flows from the power to execute.

The pardon power, far from being "conceptually and politically distinct" 550 from the prosecutorial power, is intimately connected with it. Pardons and prosecutions are really two sides of the same coin: control of the execution of federal law. As Blackstone observed, "it is reasonable that he [the Executive] only who is injured should have the power of forgiving." 551 The President is injured by infractions of federal law, because such violations demonstrate that his administration of federal law is less than perfect. It is therefore only natural that he possess the authority to pardon those who have violated the laws.

Finally, though qui tam actions contemplate prosecution by individual citizens, that is a far cry from the notion that the Chief Executive has no control over such suits. As Blackstone observes, qui tam actions are those actions in which "any such person or persons [who] will sue" receives the "forfeitures created by statute." 552 In other words, individuals may sue for monetary penalties owed by those who have violated the laws. Such actions are brought by persons "“qui tam pro domino rege, \&c., quam pro se ipso in hac parte sequitur [who prosecutes this suit as well for the king, \&c. as for himself]." 553 Though prior to commencement of the suit, the king could

about formal presidential ability to control execution. To our knowledge, no official charged with execution of laws (e.g., prosecutors, revenue collectors, marshalls) ever disregarded a direct order from Chicf Administrator Washington.

What Krent's article also demonstrates is that the President probably lacks the authority to structure administration as he sees fit. Congress creates the executive officers and departments that assist the President. If Congress, by law, does not vest control over all federal prosecution in the Attorney General, the President probably cannot grant such control to the Attorney General. See id. at 290. Krent's claim is perfectly consistent with our assertion that Congress, through the Necessary and Proper Clause, determines how to structure the administration (and, indeed, whether there will be any purely federal administration).

548. I William Blackstone, COMMENTARIES *258-59.

549. I id. at 259.

550. Lessig \& Sunstein, supra note 1 , at 21.

551. 1 William Blackstone, Commentaries *259.

552. 3 id. at $* 160$.

553. Id. 
have pardoned an individual, once a qui tam action begins, the private prosecutor "has made the popular action his own private action." 554 In other words, the king cannot control the suit.

From the originalist perspective, then, the constitutionality of qui tam suits reduces itself to two related questions: (1) Under our Constitution, does Congress have the authority to create such "popular" actions, and (2) are there any Article III restrictions on creating such causes of action? Without going into great detail, suffice it to say that qui tam actions are rather problematic. ${ }^{55}$ In any case, even Blackstone recognizes that the Executive may preemptively pardon an individual and thus thwart potential qui tam suits. At most, English practice suggests that qui tam actions can be understood as but an extremely limited exception to the rule of presidential control of all aspects of prosecution. This exception is hardly fatal to the rule of presidential superintendence of federal and state prosecutors. Once again, the history is perfectly consistent with the Chief Administrator constructed by the founding generation.

\section{Some Final Thoughts on Post-Ratification Views of the President's Administrative Role}

Excessive reliance on statutes led Lessig and Sunstein to miss the more messy and confused congressional debates behind those acts. Some Representatives clearly were concerned about the implications of having a Chief Magistrate in charge of executing all federal law. Others were not interested in implications; the Constitution had already established that the President was responsible for the execution of federal law.

The latter group was largely successful. No statute prohibited presidential superintendence. Nor did any statute even hint that the officers and institutions created therein were to be free from presidential control. Given the overwhelming evidence from the pre-ratification period indicating that the Constitution was understood to vest the President with the power to superintend the execution of federal law, we ought not to construe statutory silence as a congressional repudiation of that widely understood constitutional principle. Surely Congress would have made its intentions much more apparent had repudiation of the unitary Executive been its goal. Moreover, all statutes

554. 2 id. at *437. Penalties available through qus tam actions are "in a state of nature, accessible by all the king's subjects . . . : open therefore to the first occupant, who declares his intention to possess them by bringing his action." 2 id. at $* 438$.

555. See James T. Blanch. The Constiturionality of the False Claims Act's Qui Tam Provision. 16 HARV. J.L. \& PUB. POL'Y 701 (1993) (discussing dubious constitutionality of qui tam actions after Lujan v. Defenders of Wildlife, 112 S. Ct. 2130 (1992)). 
implicitly acknowledged the constitutional basis for the President's power of removal. ${ }^{556}$

But whatever one's reading of the congressional debates and the resulting acts, ${ }^{557}$ one cannot quibble with the notion that if one wants to gain a complete picture of post-ratification understandings of the President's administrative role, one must consider the first President's views and administrative practice. President Washington had a coherent, compelling view of the President's constitutional role, one that matched the viewpoints expressed by Anti-Federalists and Federalists alike before ratification: The President is responsible for execution of all federal law and may superintend all those statutorily authorized to execute it. Department heads and other executive officers recognized the President's commanding administrative role from the beginning. ${ }^{558}$ Far from calling into question the unitary Executive theory, the early statutes and practices actually advance that theory. As Madison so pointedly put it in his dispute with Hamilton regarding the scope

556. It would seem that the congressional understanding of the President's executive power only expanded over time. Casper notes that rather than ordering the President to investigate the destruction of the Army at the hands of the Indians, Congress conducted its own investigation. Ordering an investigation was apparently seen as an encroachment on the President's executive power because Congress would be telling the President how he ought to execute the laws. See Casper, supra note 246, at 228-29. If Casper's characterization of Congress' decision not to order the President to investigate is correct, it constitutcs conclusive proof that Congress did not hold Lessig and Sunstein's vision of the Necessary and Proper Clause, as Congress specifically thought it did not have the authority to specify the "how" of execution. Any congressional desire to insulate the President from the Administration reflected an antiquated Articlesof-Confederation thinking.

Some might believe that the members of Congress recognized the President's power to superintend execution, but that there was a great deal of confusion about exactly what constituted exccution. We disagree. We think the text and the history make clear that, prior to the Constitution's ratification, both opponents and supporters of the Constitution understood that the execution had to do with implementing or administering laws. Any supposed ignorance of this elementary concept among members of Congress, it seems to us, stemmed from a desire to rewrite the Constitution in a manner favorable to Congress. Those who claimed that the Executive lacked the power to control execution, then, were not ignorant, but rather acted out of the natural tendency to find what one wishes to find in the Constitution and ignore what is inconvenient. One might expect such problems when switching from one regime to another. Indeed, as Mr. Prakash demonstrates in Field Office Federalism, many in the founding generation incorrectly thought that Congress could constitute state courts as federal courts by statute, without the requirements of presidential nomination and Senate confirmation. See Prakash, supra note 226, at 2030-31.

557. Though Lessig and Sunstein discern a pattern in postratification statutes that supposedly supports their interpretation of the Opinions and Inferior Officers Appointments Clauses and the distinction between administrative and executive law, we see no such pattern. Let us consider the administrative institutions created by Congress. State and War were executive departments headed by principal officers. Treasury was a department led by a head. The Postmaster (in charge of an Office, but not a department) was explicitly put under the President's control in 1789, but not in 1792. In 1798, the Department of the Navy was created, with a Navy Secretary as its "chief." See generally Lessig \& Sunstein, supra note 1, at 27-30. Where Lessig and Sunstein see "a variety of structures, not a single one," id. at 23, we sce one. Administrative practices and statutory history suggest that all these officers and departments were exccutive.

558. Historians Elkins and McKittrick observe that once created, there was no doubt that the departments were agents of the President. Stanley Elkins \& ERIC MCKitTRICK, THE AgB of FEDERALISM 52 (1993). 
of the Executive's authority, "[t]he natural province of the executive magistrate is to execute laws."

\section{CONCLUSION}

We have arrived at the conclusion of a long argument, having established several points. First, our Constitution creates a trinity of types of governmental powers and personnel. The constitutional text thus forecloses historical arguments for a headless fourth branch of government. Second, the Vesting Clauses of Article II (and Article III) are general grants of power that are explicated (to different degrees) by the subsequent Sections of those Articles. The Executive Power Clause in particular gives the President the authority to execute federal law. Third, since the President's grant of "the executive Power" is exclusive, Congress may not create other entities independent of the President and let them exercise his "executive Power." Fourth, the hierarchical structure of Article $I I$ is further confirmed by the language of the Take Care, Opinions, and Militia Clauses. Finally, the Necessary and Proper Clause does not give Congress any power to deviate from the basic constitutional structure. Congress can no more use that Clause to abolish the unitary Executive than it could use it to abolish the states. The pre-ratification history fully supports these understandings, and little in the post-ratification history calls any of this into question. Indeed, there is more post-ratification evidence to support our textual theories. We should not be surprised that the founding generation read the text according to its "plain meaning."

Having said all this, we would be the last to deny that there are scraps of evidence that can be dutifully collected and woven together to establish that some members of the First Congress (and its successors) may have been confused some of the time about the full extent and nature of the President's powers of control over subordinate officials in the executive branch. ${ }^{560}$ Members of the post-Reconstruction Congresses likewise exhibited similar confusion some of the time about the effects of the newly ratified Fourteenth Amendment on various forms of legal segregation.

559. James Madison, Letters of Helvidius No. I (Aug.-Sept. 1793), in 6 THE Wrmisas of JAMES MADison 138, 145 (Gaillard Hunt ed., 1906), cised in Monaghan, supra note 6, at 21 n.96.

560. As Professor Harrison has pointed out to us. some of the evidence that Lessig and Sunstetn focus on involves a distinction about which the Constitution is not very clear. the line between exereises of executive governmental power and exercises of "powers" that are in some ways nongovernmental altogether. Thus, although the Constitution is very clear in its division of governmental powers into three categories, it is quite obscure about problems of execution once the publid/private line has become blurred.

The problem is that the Framers did not think much about the public/private line. Difficulties arise respecting bodies such as territorial governments. which carry out functions that put pressure on the line between federal government power and the private sector. See Gary S. Lawson. Territoral Govemments and the Limits of Formalism, 78 CAL. L. REV. 853 (1990) (discussing separation-of-powers problems involving territorial governments). The Framers trinitarian catechism is obviously strained in such situations, but it is less strained by calling these functions executive than it would be by calling them anything else. 
What this suggests is that if a case is to be made against the unitary Executive, and such a case can most assuredly be made, it must rest on a nonoriginalist theory such as Henry Monaghan's precedent-driven common law constitutionalism ${ }^{561}$ or Bruce Ackerman's theory of three originalisms. ${ }^{562}$ A common law constitutionalist or an Ackermanian who opposed the theory of the unitary Executive might have a theoretically consistent argument, but we believe that the Lessig and Sunstein thesis cannot be right given their article's originalist premises.

An Executive without the power to execute is gibberish linguistically and bears no relationship to the Chief Executive Magistrate created by the Constitution. Such a view of the Executive is typically advanced by those who believe that administration of federal law should be kept independent of the President. Individuals who believe in the detached, depoliticized, and "scientific" administration of federal law undoubtedly sincerely regard such an administrative structure to be superior to one superintended by the President, who is, after all, a mere creature of politics. This belief in the soundness and wisdom of an "independent" administration, though genuine, has little relevance to or grounding in the Constitution. As the Framers, ratifiers, ratification opponents, members of the First Congress, and President Washington understood, the Constitution grants the President the authority to superintend the administration of federal law. ${ }^{563}$ There are no caveats. There are no exceptions.

We can now appreciate our Constitution's elegant simplicity. Our grade school and high school civics teachers were right all along: The Constitution separates our federal government into three branches, each exercising one of three types of powers. There may be some portions of the "structural Constitution" that are less than clear, but the Executive Power Clause of Article II is not one of them. The Framers and ratifiers consciously and deliberately chose to put one person in charge of executing all federal laws. Those who would question this must necessarily view the members of the

561. For a thoughtful discussion of the role of precedent in constitutional law, see Henry P. Monaghan, Stare Decisis and Constitutional Adjudication, 88 CoLUM. L. REV. 723 (1988). Note, however, the continuing importance of text to Professor Monaghan. Monaghan, supra note 6. For an originalist argument against common law constitutionalism and the bindingness of precedent, see Lawson, supra note 349, at 25-28.

562. 1 Bruce ACKerman, We the People (1991); Bruce A. Ackerman, The Storrs Lectures: Discovering the Constitution, 93 YALE L.J. 1013 (1984).

563. Lessig and Sunstein assert that unitarians believe that the Constitution enshrines a "single organizational value-unitariness-at the expense of other possible governmental values—such as disinterestedness or independence." Lessig \& Sunstein, supra note 1, at 9. Their characterization of the unitarians' understanding of the values enshrined in the Constitution is much too superficial and narrow. As Mr. Prakash has argued elsewhere, the Framers and ratifiers thought that having one Executive would promote an energetic and accountable administration. See generally Prakash, supra note 6; see also Calabresi, Some Normative Arguments, supra note 9 (advancing modern normative case for unitary Executive). The values of disinterestedness and independence did not animate the founding generation when it came to execution. 
founding generation as political naifs, with no knowledge of Locke, Montesquieu, or Blackstone; with no memory of the failed congressional administration under the Articles; and with no understanding of the centrality of administration in the success or failure of the great new experiment. This view disregards what the Founders said about the Constitution in the ratification debates. And most damning of all, it distorts the Constitution's text. Tempting though it may be, we must resist our propensity for making the Constitution into something more complex and inscrutable than it really is. 
